\title{
As múltiplas vozes da Caravana Farkas e a crise do "modelo sociológico"
}

Dissertação apresentada ao Programa de Ciências da Comunicação, na área de Estudo dos Meios e da Produção Mediática, da Escola de Comunicações e Artes da Universidade de São Paulo, como exigência parcial para obtenção do título de Mestre, sob a orientação do Prof. Dr. Henri Pierre Arraes de Alencar Gervaiseau. 


\section{As múltiplas vozes da Caravana Farkas e a crise do "modelo sociológico"}

Dissertação apresentada ao Programa de Ciências da Comunicação, na área de Estudo dos Meios e da Produção Mediática, da Escola de Comunicações e Artes da Universidade de São Paulo, como exigência parcial para obtenção do título de Mestre, sob a orientação do Prof. Dr. Henri Pierre Arraes de Alencar Gervaiseau. 
BANCA EXAMINADORA

+

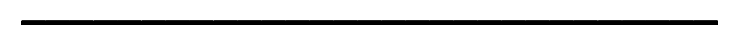

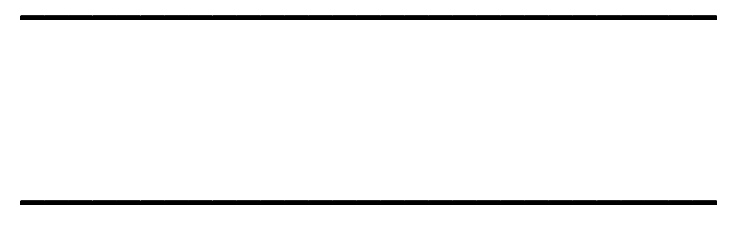

DATA 


\section{RESUMO}

Caravana Farkas é o um conjunto de 20 documentários produzidos por Thomas Farkas entre 1964 e 1969. Este trabalho analisa verticalmente três destes filmes - "Viva Cariri!" (1970), de Geraldo Sarno; “De Raízes e Rezas, entre outros” (1972), de Sergio Muniz e "Frei Damião: Trombeta dos Aflitos, Martelo dos Hereges" (1970), de Paulo Gil Soares -, buscando situá-los em relação à tradição documentária brasileira que os antecedem e ao documentário brasileiro da década de 70 . As análises partem de sugestões imanentes aos filmes, em detrimento do contexto de produção; têm como foco as relações entre som e imagem internas aos filmes; e se apóiam em ferramentas teóricas ligadas especificamente ao filme documentário, como a categoria de voz do texto e os variados modos documentários. A partir do trabalho de análise, esse corpus pode ser caracterizado como de transição. Apesar de estarem ainda ligados às raízes do documentário expositivo brasileiro de cunho sociológico e ao paradigma da "voz do dono", os filmes apontam para procedimentos que se tornarão mais comuns na produção brasileira posterior, na qual a busca da "voz do outro" ganha consistência.

Palavras-chave: documentário brasileiro, Caravana Farkas, modelo sociológico, voz do texto e cultura popular. 


\section{ABSTRACT}

Caravana Farkas is a selection of 20 documentaries produced by Thomas Farkas between the years of 1964 and 1969. This dissertation vertically analyzes three of said films - "Viva Cariri!" (1970), by Geraldo Sarno; "De Raízes e Rezas, entre outros" (1972), by Sergio Muniz, and "Frei Damião: Trombeta dos Aflitos, Martelo dos Hereges" (1970), by Paulo Gil Soares -, seeking to situate them in relation to the Brazilian documentary tradition that preceded them and the Brazilian documentaries of the 70s. These analyses stem from suggestions that are inherent to the film, in detriment to the context of the production. They also focus on relations between sound and image within the films, and they rely on theoretical tools linked specifically to documentary films, as a category of textual voice and a variety of documentary modalities. From such analyses, this corpus can be characterized as transition. Despite still being linked to the roots of Brazilian expository documentaries of a sociological nature, and to the paradigm "the voice of the owner", the films paved the way to procedures that will become the most common within the following Brazilian production, in which the search for "the voice of the other" gains ground.

Key-words: Brazilian documentary, Caravana Farkas, sociological model, the voice of the text and popular culture. 


\section{AGRADECIMENTOS}

Agradeço a

Nando e Quilha por todo incentivo e pelas valiosas revisões e contribuições.

a Ale, pelo carinho, paciência e apoio.

a Lucia, Alyne e Adriana, minhas irmãs de todas as horas.

a Vera, minha avó querida.

a Malu e Roberto, por acreditarem na importância deste trabalho.

a Tomás, por me apresentar aos documentários.

a Thomaz Farkas, pelos filmes e pela inspiração.

a Henri Gervaiseau pelo longo diálogo e intermináveis leituras.

a Ismail Xavier e Marcius Freire, pelas fundamentais críticas. 
SUMÁRIO

Introdução | pág. 08

Capítulo 1 | pág. 18

Caravana Farkas: Visão Panorâmica

Capítulo 2 | pág. 41

"Viva Cariri!" e a fragmentação coesa de Sarno

Capítulo 3 | pág. 80

"Frei Damião" e o locutor invisível

Capítulo 4 | pág. 111

"De raízes e Rezas, entre outros": um caleidoscópio sertanejo

Conclusão | pág. 145

Bibliografia | pág. 158 


\section{INTRODUÇÃO}

Caravana Farkas é o nome dado a um conjunto de documentários produzidos por Thomas Farkas entre 1964 e 1969. Primeiramente, o título se referia a vinte documentários sobre a cultura popular nordestina produzidos em 1969 e reunidos sob o título de "A Condição Brasileira”. Os episódios, com durações de 10 a 40 minutos, foram dirigidos por Geraldo Sarno, Paulo Gil Soares e Sérgio Muniz; filmados de forma simultânea no Ceará, em Pernambuco e no Recôncavo Baiano, entre março e maio de 1969; e editados entre 1969 e 1972 . Posteriormente passaram a ser incluídos na Caravana outros quatro curtas-metragens produzidos por Farkas em 1964 - "Nossa Escola de Samba", de Manuel Horácio Gimenez, "Os Subterrâneos do Futebol", de Maurice Capovilla, "Viramundo", de Geraldo Sarno e "Memórias do Cangaço", de Paulo Gil Soares - que integraram o longa-metragem "Brasil Verdade". Assim, somando-se estas duas fases de produção, obtêm-se a marca de 24 curtas e médias-metragens ${ }^{1}$.

"A Condição Brasileira" foi inteiramente realizada com financiamento privado e apesar de suas precárias condições de produção - três equipes reduzidas trabalhando de forma simultânea, com poucos recursos - a produtividade do empreendimento é ainda hoje digna de nota. Os documentários nunca foram exibidos comercialmente e sua difusão acabou tornando-se limitada a círculos restritos, fazendo com que os resultados da Caravana permaneçam ainda bem pouco conhecidos. Apesar disso, trata-se de uma experiência inovadora, ao propor um modelo de produção de documentários ao mesmo tempo culturalmente relevante e que se pretendia - ainda que na prática isso não tenha se confirmado - viável em termos mercadológicos. A pergunta que fica no ar é: para além de sua evidente importância histórica, até que ponto a Caravana Farkas é relevante em termos de seus resultados estéticos e de linguagem em relação à produção brasileira de documentários?

\footnotetext{
${ }^{1}$ Na mostra Caravana Farkas, realizada em 1997 no Centro Cultural Banco do Brasil, com curadoria de Sérgio Muniz, foram incluídos também outros 14 títulos de filmes - incluindo uma obra de ficção - produzidos por Thomaz Farkas entre 1964 e 1980, totalizando assim 38 obras.
} 
Buscando responder esta questão, este trabalho pretende se concentrar na análise fílmica, em detrimento da análise de contexto. Assim, delimita seu foco de atenção aos documentários englobados dentro do título "A Condição Brasileira” para investigar como é que esta produção se relaciona com os procedimentos e opções estilísticas da tradição documentária brasileira que a antecedeu - em especial o documentário expositivo ${ }^{2}$ de cunho sociológico da primeira metade da década de 60 - e de que forma estes filmes prefiguram questões que serão abordadas pelo documentário brasileiro da década de 70. Dentro deste conjunto de 20 filmes, foram selecionados três títulos, que serão analisados em profundidade, em termos estruturais e estilísticos: “Viva Cariri!” (36’, 1970), de Geraldo Sarno; “De Raízes e Rezas, entre outros” (37’, 1972), de Sergio Muniz e “Frei Damião: Trombeta dos Aflitos, Martelo dos Hereges” (20', 1970), de Paulo Gil Soares.

Essa seleção obedeceu alguns critérios. Em primeiro lugar considerei importante que os três diretores fossem contemplados pelas análises, já que cada um dos três conjuntos de filmes tem características próprias em relação ao tema e o estilo. A partir daí, busquei, dentro da produção de cada um deles, os trabalhos mais indisciplinados em relação ao "modelo sociológico" conforme definido por Jean-Claude Bernardet - e mais interessantes do ponto de vista do estabelecimento de relações com a produção documentária brasileira posterior.

\footnotetext{
${ }^{2}$ Adoto aqui a definição de documentário expositivo de Bill Nichols. Para Nichols o modo expositivo é um dos seis modos de representação, nos quais o gênero documentário de divide: poético, expositivo, participativo, observacional, reflexivo e performático. Nichols associa estes modos de representação a diferentes momentos históricos da evolução do documentário, ainda que estas conexões não sejam exclusivas ou definitivas. Eric Barnouw, em seu livro "History of the non-fiction film", propõe uma leitura histórica da evolução do documentário que passa pela identificação dos diferentes papeis assumidos pelos documentaristas ao longo da história. Grosso modo, as periodizações de Barnouw (mais histórica) e de Nichols (mais ligada à tentativa se sistematizar uma teoria do documentário) guardam semelhanças. Voltando a definição de Nichols, o modo expositivo está ligado a uma postura argumentativa, na maior parte das vezes apoiada num comentário com voz de autoridade através do qual o filme se dirige diretamente ao espectador. No filme expositivo, todos os elementos se articulam de forma subordinada a esta voz de autoridade que expõe um argumento. Em geral, a imagem tem um papel secundário, de ilustração ou esclarecimento do que é dito. Entre os exemplos que Nichols utiliza para caracterizar este modo estão diversos filmes da década de 30 , entre eles alguns dos filmes ligados ao movimento britânico liderado por John Grierson. Assim, ao longo do texto a expressão "tradição griersoniana" irá se referir a este movimento britânico, fortemente identificado com o modo expositivo, conforme definido por Nichols. Ao mesmo tempo, este modo expositivo será freqüentemente associado ao "modelo sociológico" brasileiro da primeira metade da década de 60 , como se verá a seguir. Ver NICHOLS, 1991 e NICHOLS, 2005, p. 142-146.
} 
É necessária a abertura de um pequeno parêntese para esclarecer a referência - que será constante ao longo desta pesquisa - à definição do que seria um certo documentário sociológico brasileiro dos anos 60. Do ponto de vista da proposta de Bernardet - estabelecida, coincidentemente, a partir da análise de "Viramundo", de Geraldo Sarno - este "modelo sociológico" poderia ser entendido como um modo de fazer documentário, onde a estrutura do filme se organiza a partir de uma voz em off autorizada e arrogante, "a voz do dono", que apresenta uma tese. Resumidamente, a comprovação desta tese se dá a partir da articulação entre o locutor principal, que representa a voz do saber, e os entrevistados, que falam apenas sobre suas próprias experiências, sem nunca propor generalizações. ${ }^{3}$

Ainda que esta definição não possa ser aplicada de maneira irrestrita ao documentário brasileiro da década de 60 - uma vez que se trata da identificação de alguns mecanismos presentes em documentários específicos, e não um conceito teórico que possa ser desprendido totalmente dos filmes aos quais se refere -, ela aponta para uma tendência expositiva, muitas vezes com pretensões sociológicas, bastante comum nos documentários da época. De alguma maneira, enquanto na Europa e nos Estados Unidos, o cinema direto e o cinema verdade rompiam com a tradição griersoniana, no Brasil a filiação a este documentário de tese ainda pode ser sentida claramente na produção dos anos 60 .

Assim, a seleção de filmes para esta analise buscou enfocar filmes em que o caráter expositivo e a articulação a partir da voz em off autorizada fossem matizados, através de novos recursos e procedimentos que ganhariam espaço na produção documentaria brasileira da década seguinte. Apesar de não ser possível definir de forma unívoca o que seria esse novo documentário brasileiro da década de 70, Bernardet identifica algumas tendências de ruptura em alguns filmes desta época, que poderiam ser reunidas no conceito da "voz do outro". ${ }^{4}$

\footnotetext{
${ }^{3}$ Para uma exposição mais aprofundada deste modelo, ver: BERNARDET, 2003, páginas 15 a 57.

${ }^{4}$ Ver BERNARDET, 1979-80; e BERNARDET, 2003.
} 
Em outras palavras, tratar-se-ia da busca, através de uma diversidade de procedimentos, de um espaço maior para a experiência subjetiva deste outro sendo retratado - quase sempre um outro de classe -, que deixaria de ser submetido à voz do saber. Na prática, isto pode significar um maior espaço para a entrevista, uma diminuição na presença do locutor, uma revalorização da experiência religiosa individual, um questionamento da objetividade do registro cinematográfico e até, em última instância, colocar de fato a câmera nas mãos do personagem retratado.

Considerando que a escolha dos filmes priorizou o distanciamento dos filmes em relação ao documentário sociológico e a presença de elementos de ruptura com este método, os três documentários escolhidos não são, portanto, os mais típicos dentre cada um dos três conjuntos. Ao contrário, como as análises buscarão mostrar, os três filmes escolhidos se diferenciam do conjunto de filmes da Caravana que é, de maneira geral, mais conservador e mais fortemente filiado a um modo expositivo de organização do que esta seleção.

Assim a hipótese que a pesquisa busca comprovar é a de que estes três filmes, de diferentes maneiras, podem ser classificados como trabalhos de transição ao dialogarem com duas tendências do documentário brasileiro: a "voz do dono", característica do "modelo sociológico"; e "a voz do outro" buscada pelos documentaristas brasileiros ao longo da década de setenta. Para identificar os modos como esta transição se esboça, as análises investigam algumas questões recorrentes como: o uso da narração em off que articula uma tese, as estratégias de afirmação da "voz do texto", a participação e o tratamento dos entrevistados e o tratamento dos temas, em especial a religião e a produção cultural popular.

Tomo emprestado de Bill Nichols ${ }^{5}$ a categoria de "voz do texto", que será utilizada muitas vezes ao longo deste trabalho. Para Nichols a "voz do texto" é mais do que a narração ou o diálogo -

${ }^{5}$ Ver NICHOLS, 2005. 
ela não corresponde à voz literal do autor -, é um padrão intangível formado pela interação de todos os códigos de um filme. Em outras palavras, é a maneira como o filme organiza aquilo que ele apresenta. Dado o uso recorrente desta categoria na dissertação, julgo necessária uma rápida exposição de algumas questões trabalhadas por Nichols. O autor defende a idéia de que a disputa de formas na evolução do documentário se centra na questão da voz, e que diferentes tradições buscam constantemente novas estratégias ligadas à voz textual para melhor representar "as coisas como elas são". Nichols parte de Grierson, e do estilo de discurso direto, onde a exposição de uma tese se organiza a partir de uma narração em off supostamente autorizada e quase sempre arrogante; passa pelo cinema direto norte-americano, que suprime completamente o comentário e as entrevistas despertando dúvidas sobre o ponto de vista do autor; para chegar até às novas formas que estas questões tomam na década de 70 .

O autor considera que os documentários observacionais da década de 60 parecem deixar por conta do espectador a significação do filme e abrem mão da argumentação direta em nome de uma pretensa revelação histórica. Embora suas estratégias organizacionais estabeleçam uma "leitura preferencial", estes filmes exigem uma leitura vigorosa e retroativa do texto para que se possa ouvir a voz do sistema textual como um nível distinto dos sons e das imagens. Já nos anos 70, segundo sua periodização, Nichols avalia que os cineastas restituem a enunciação direta. $\mathrm{Na}$ maior parte das vezes isso acontece através de entrevistas em que os atores sociais -pessoas comuns, seguindo a tradição do direto - se dirigem diretamente ao público. O testemunho pessoal substituiria o julgamento histórico, revelando a confiança dos cineastas na possibilidade de reconstruir a história por meio do relato oral. Assim, as entrevistas seriam uma forma de evitar a onisciência autoritária e o reducionismo didático da antiga narração em off. Se os fatos não podem falar por si mesmos (como mostrou o cinema observacional), nem uma única voz pode falar com autoridade definitiva (haja vista a tradição griersoniana), através das entrevistas a autoridade se tornaria difusa. Neste novo momento, o cineasta pode participar do diálogo, mas recusando uma posição privilegiada em relação às outras vozes. E - embora os personagens 
ainda sejam cúmplices da voz dominadora do próprio texto - o efeito de do relato pessoal sobre o espectador é diferente daquele da voz autorizada.

Dentro desse novo esquema organizacional Nichols levanta alguns dos possíveis problemas: a dificuldade de manter uma distância entre a voz dos entrevistados e a "voz do texto", as estratégias ideológicas que se escondem no apagamento da voz do texto por detrás dos personagens, o risco de fazer o filme um simples endosso dos testemunhos, a perda do senso de hierarquia entre as vozes, a idealização do personagem contrariando sua condição de pessoa comum, entre outras coisas.

Para ele, se a voz autoritária dos anos 60 acreditava ser capaz de fazer um juízo objetivo e verdadeiro da realidade, essa questão ainda está para ser resolvida nos anos 70: não ser capaz de assumir a voz do texto é se recusar a assumir que o filme não pode criar uma representação objetiva da realidade. Em suma, os diferentes níveis de afirmação e de explicitamente da voz do texto, a busca de um maior efeito de veracidade, e as especificidades do documentário observacional e do documentário de entrevistas são questões discutidas por Nichols que irão permear as três análises apresentadas nessa pesquisa.

Vale destacar que, embora as periodizações propostas por Nichols e por Bernardet não sejam correspondentes - inclusive porque no contexto brasileiro não se pode falar em tradições nitidamente delineadas -, é possível fazer algumas aproximações entre elas. A voz de autoridade identificada por Nichols como tributária da tradição griersoniana guarda semelhanças com a "voz do dono", do "modelo sociológico". Já a valorização na década de 70 do depoimento, matizando esta voz de autoridade, conforme levantado por Nichols, talvez seja comparável ao que Bernardet classifica como a busca da "voz do outro".

Dessa forma, como se pode ver, as análises não irão se apoiar no instrumental da teoria da narrativa, mas em conceitos mais ligados a teoria e história do documentário. Ao lado de Jean 
Claude Bernardet e Bill Nichols - de quem, além do conceito de "voz do texto", é utilizada a fundamental definição de modos documentários -, destaca-se também, como outra referência constante, o trabalho de Roger Odin, especificamente no que diz respeito aos diferentes modos de enunciação e de produção de sentido que caracterizam a relação espectador/filme, em especial os modos documentarizante e ficcionalizante, conforme se verá mais detalhadamente no capítulo dois. Para Odin diferentes modos de produção de sentido podem ser combinados dentro de um mesmo filme, dependendo tanto da forma - mais ou menos assumida - como o enunciador de coloca, quanto das condições nas quais se estabelece a relação entre o espectador e o texto. ${ }^{6}$ Neste mesmo capítulo, serão desenvolvidos dois conceitos também amplamente inseridos na pesquisa: "ator natural" e "dramaturgia natural". Estas definições, elaboradas por Sérgio Santeiro no final da década de setenta ${ }^{7}$, abrem perspectivas interessantes de análise, a partir da relação diretor/personagem e dos recursos mobilizados por essa personagem para obter a melhor representação possível de si próprio.

Em relação ao método de análise, foi buscada uma compreensão de dupla natureza dos filmes. De um lado, um entendimento de sua estrutura geral, a fim de identificar como dialogam as diversas vozes do texto e como estas são organizadas pela "voz do texto". De outro, está um olhar mais vertical em relação a seqüências chaves para a definição do estilo destes trabalhos, que serão exploradas em detalhe, a partir das relações que nelas se estabelecem entre som e imagem. Nesse sentido, o foco do trabalho está na investigação de questões imanentes ao filme. Assim, as questões de contexto serão abordadas a partir de informações ou sugestões presentes nos textos analisados e não o inverso.

As questões de contexto, entretanto, estão colocadas num panorama geral histórico que antecede as análises. A fim de situar historicamente os filmes analisados, o primeiro capítulo "Caravana Farkas: Visão Panorâmica" - busca recuperar as origens desta produção e entendê-la

\footnotetext{
${ }^{6}$ Ver ODIN 1984 e 2005.

${ }^{7}$ Ver SANTEIRO, 1978.
} 
do ponto de vista de seu conjunto a partir da maneira como ela se estruturou. O capítulo começa na formação de um grupo de cineastas ao redor da figura de Thomas Farkas no início da década de 60 e passa pela realização dos primeiros quatro curtas-metragens da Caravana, o "Brasil Verdade"; dedicando um certo espaço a caracterização desses trabalhos e de sua ligação com o "modelo sociológico" de Bernardet. Em seguida, todas as etapas de produção de "A Condição Brasileira" são descritas: das primeiras viagens ao Nordeste, passando pela produção propriamente dita até a finalização e exibição dos documentários.

Foram valorizados aqui os depoimentos dos participantes sobre este período, além da tese de doutorado de Thomaz Farkas em que ele, ao propor uma síntese de seu método de trabalho para a produção de documentários, revela muito sobre os princípios que nortearam a realização destes filmes ${ }^{8}$. Em relação ao contexto de produção, o capítulo procura explorar de que maneiras os filmes, ao buscar o retrato do Brasil autêntico através do registro do fazer do homem nordestino, colocam-se em relação à discussão sobre o nacional e o popular que tem lugar no cinema brasileiro da década de 60. Finalmente, discute o diálogo destes realizadores com algumas tradições documentárias como o movimento documentarista britânico da década de 30 - freqüentemente citado por Farkas e do qual a o documentário expositivo brasileiro da década de 60 ainda é tributário - e o cinema direto - cuja influência se deu menos do ponto de vista teórico e mais no que diz respeito à incorporação de inovações técnicas.

O segundo capítulo apresenta a primeira das três análises que constituem o corpo principal do trabalho. O primeiro filme a ser analisado é “Viva Cariri!", de Geraldo Sarno. Entre os filmes produzidos por Sarno na Caravana, este é o de maior fôlego e aquele para qual Sarno dedicou o maior tempo de filmagem. Sarno retorna a Juazeiro (que para ele representava uma síntese do sertão e que já havia lhe rendido alguns filmes na fase de preparação da Caravana) para contrapor no filme dois aspectos da região - o místico e o econômico - e propor uma relação entre a religiosidade local e sua decadência sócio-econômica. A análise revela como esta

\footnotetext{
${ }^{8}$ Ver FARKAS, 1972.
} 
dualidade presente no tema se estende a outros aspectos do filme, como seu estilo (que parte de um registro mais naturalista para uma gradual desnaturalização das imagens), ou sua abordagem da religião (que varia entre o retrato de experiências mais personalizadas e a exploração do comportamento da massa). Em relação ao documentário de caráter expositivo, Sarno reduz a participação do narrador fora de campo, mas não abre mão da tese. Através de uma montagem aparentemente fragmentada, afirma claramente a "voz do texto" e mostra que os modos de organização social e econômica da região são incompatíveis com o processo de modernização, traçando uma ligação clara entre a dominação política e a religiosidade alienada. O capítulo explora a variedade de recursos articulados por Sarno - entrevistas, imagens observacionais, locução e a importação de elementos da cultura popular local - buscando compreender como cada um destes itens modula um movimento da "voz do dono" à "voz do outro".

O terceiro capítulo, "Frei Damião e o locutor invisível", analisa o filme de Paulo Gil Soares "Frei Damião: Trombeta dos Aflitos, Martelo dos Hereges", também do ponto de vista de seu modo de articulação de vozes. O filme explora, a partir do registro de uma viagem de Frei Damião à cidade de Taperoá, na Paraíba, em 1969, a questão do fanatismo religioso e comprova, através de uma montagem com alto teor de encadeamento discursivo, que o fanatismo favorece a igreja. A partir do conceito de "voz do texto", o capítulo mostra que o filme reduz ainda mais a participação da narração em off, mas preserva a tese de fundo - que surge atrás de uma pergunta - ao redor da qual o material fílmico se organiza. O recurso básico do documentário é a entrevista, explorada de duas formas diferentes. Na sua primeira parte, o filme apresenta depoimentos de populares, que relatam milagres atribuídos a Frei Damião, sem que se afirme a voz literal do autor. Em uma segunda etapa, o documentário explora a entrevista de Frei Damião e uma nova dinâmica se cria. Com a participação da voz do entrevistador e um alto nível de intervenção da montagem, articula-se um verdadeiro embate entre as vozes do texto e do entrevistado, do qual a voz do texto sai ganhando. A análise revela que, por um lado, o filme inova ao antecipar o formato do documentário de entrevistas; mas por outro, a filiação ao 
"modelo sociológico" ainda é sentida, uma vez que a tese apresentada organiza-se à revelia destes entrevistados.

A terceira e última análise surge no capítulo quatro, "De Raízes e Rezas - o autor estilhaça a tese". Como o título sugere, o último filme desta seleção - "De Raízes e Rezas, entre outros", de Sérgio Muniz - radicaliza o afastamento que os outros dois documentários insinuam em relação ao documentário de cunho sociológico e abre mão da tese de fundo. Numa colagem de canções populares e imagens observacionais, editada dois anos depois das filmagens da Caravana, Muniz cria um painel iconográfico do sertão nordestino, onde os temas da Caravana são sintetizados. Assim como nas outras análises, o capítulo se estrutura a partir das diferentes vozes que compõem este painel e busca investigar quais as estratégias de afirmação da "voz do texto". Além das canções e das citações audiovisuais diversas, o filme também trabalha com entrevistas que, como se verá, deixam a "voz do outro" ser ouvida com mais clareza. Ao mesmo tempo, neste mapeamento de estratégias, o que se revela é que, embora a tese tenha sido deixada de lado, é altíssimo o nível de controle da "voz do texto".

A grande mudança, no entanto, surge justamente deste controle. O enunciador de "De Raízes e Rezas" manipula sem pudores o material fílmico, assumindo-se inteiramente e reafirmando o caráter de representação mediada do documentário. Finalmente, o capítulo discute os dois pólos estéticos e ideológicos com os quais o filme dialoga. O primeiro é a alegoria profética de "Deus e o Diabo na Terra do Sol”, de Glauber Rocha, citado inúmeras vezes ao longo do documentário e que afirma o telos da revolução. No outro extremo, a canção tropicalista surge com força, apontando para uma nova sensibilidade e uma nova maneira - mais irônica e bem humorada - de lidar com a falência do projeto revolucionário de esquerda. Na tensão entre a esperança e o deboche o filme dá um passo adicional em direção a um novo modo de fazer documentário. 


\section{CAPÍTULO 01 | CARAVANA FARKAS: VISÃO PANORÂMICA}

Embora este trabalho tenha como foco as análises fílmicas - que não estão vinculadas a considerações sobre o contexto de produção destas obras - é interessante traçar um panorama histórico da Caravana Farkas, e situar essa produção dentro da evolução do documentário brasileiro, principalmente no sentido de identificar tendências e procedimentos com os quais esses filmes se relacionam.

Esse diálogo pode se dar em dois níveis. O primeiro nível, externo ao filme, tem a ver com a relação declarada que o realizador estabelece com a produção que lhe é contemporânea, bem como seus objetivos formais e estéticos. O segundo é interno ao filme e tem a ver com a maneira como essas intenções são efetivamente trabalhadas.

As análises dos capítulos seguintes estão voltadas especificamente para as soluções encontradas internamente por cada um dos documentários e procuram, a partir de um olhar historicamente distanciado, identificar formas de diálogo entre esses filmes e diferentes métodos de realização, anteriores e posteriores a eles, apontando o seu caráter transitório. Por ora, o intuito é de acompanhar os vários estágios da realização deste conjunto de filmes, observando as relações que eles declaradamente buscam estabelecer com as tradições e as inovações técnicas que lhe precederam. Assim, num primeiro momento, buscarei situar o contexto histórico e estético no qual a iniciativa de Thomas Farkas tem início.

Segundo a avaliação de Sérgio Muniz, os filmes da Caravana Farkas foram possíveis não apenas em função da disposição de Farkas como produtor, mas também graças ao momento específico pelo qual o cinema brasileiro passava, caracterizado, de um lado pela renovação estética proposta pelo Cinema Novo, e de outro pelas novas técnicas que se introduziram no cinema na década de 60. 
O som direto e as câmeras leves permitiam que se começasse a utilizar a entrevista sincrônica, "sendo possível dar voz ao personagem brasileiro, ao cidadão brasileiro, coisa que até então não havia. O que havia eram os documentários de encomenda de Jean Manzon, em que havia sempre um narrador contando como o Brasil era fantástico, e sempre achando alguém que dizia o que era a realidade...". 9

O documentário brasileiro estava em plena fase de transição. Os novos documentaristas tinham como referência não mais os documentários-propaganda de Jean Manzon ou os documentários didáticos do INCE. A partir de "Arraial do Cabo" (1959), de Paulo César Saraceni, e "Aruanda" (1960), de Linduarte Noronha, são estabelecidos os marcos de fundação do novo documentário brasileiro - ou do primeiro documentário brasileiro, segundo de Thomaz Farkas. Os filmes foram referenciais para toda uma nova geração de cineastas - na qual se incluía o grupo ao redor de Farkas - que viu nos dois trabalhos um ponto de partida para a definição do que seria um “estilo nacional de cinema". Os documentários traziam uma nova temática - "Arraial do Cabo" retrata uma colônia de pescadores em Cabo Frio, e "Aruanda" aborda a Festa do Rosário em Serra Talhada, na Paraíba -, e uma nova abordagem em relação à representação do povo e da natureza nordestina.

A câmera na mão de Saraceni e a fotografia estourada de "Aruanda" - que parecia pela primeira vez representar adequadamente a luminosidade do sertão - surgiam como uma abertura de caminhos estéticos para essa geração. Para Maurice Capovilla, além das inovações de linguagem, estes documentários suscitavam também discussões sobre novos temas e novos modos de produção: "Fundamentalmente, havia três pontos: 1) um novo tipo de produção, sem escrúpulos técnicos; 2) o homem como tema, isto é, a tentativa de encontrar o homem brasileiro, o homem da rua, o homem da praia e do sertão; a busca deste homem, de sua maneira de falar, de andar,

\footnotetext{
${ }^{9}$ Depoimento de Sérgio Muniz citado em CADERNOS DE RTV/ 01
} 
de se vestir, de existir, seu trabalho, sua estrutura mental, etc; 3) uma nova linguagem, que se esboçava naqueles filmes". ${ }^{10}$

Ao mesmo tempo, de maneira paradoxal, estes filmes inovadores não se relacionavam diretamente com as novidades no campo do documentário fora do Brasil. De certa forma, a vanguarda do documentário brasileiro se constrói à margem tanto do documentário brasileiro da década de 50, quanto das influências do cinema direto ${ }^{11}$.

Ao comentar a origem de "Aruanda", o próprio Linduarte Noronha diz que seu início como cineasta se liga mais a seu trabalho jornalístico do que propriamente à influência cinematográfica $^{12}$. Em outro depoimento ${ }^{13}$, Linduarte dá como referências Cavalcanti e Flaherty, que, do ponto de vista da vanguarda do documentário internacional, representavam opções estéticas ultrapassadas. Sobre isto, Galvão e Bernardet comentam que "a teoria que se relaciona com a prática da realização de 'Aruanda' não é a que lhe deu origem e sim a que o filme suscitou". Esta teoria que surge a partir dos filmes está relacionada aos elementos que comporiam um novo cinema nacional, tais como: assunto brasileiro, o povo como tema, produção barata e equipe pequena.

Em um artigo, publicado no "Suplemento Dominical do Jornal do Brasil" em 1960, no Rio de Janeiro, Glauber afirma: "Linduarte Noronha e Rucker Vieira entram na imagem viva, na montagem descontínua, no filme incompleto. 'Aruanda', assim, inaugura o documentário brasileiro nesta fase de renascimento que atravessamos. (...) Os filmes curtos começam a surgir de Paulo Saraceni, Mário Carneiro, Linduarte Noronha, Rucker Vieira, Joaquim Pedro, Marcos

\footnotetext{
${ }^{10}$ Depoimento citado em GALVÃO, BERNARDET, 1981, p.196 e 197.

${ }^{11} \mathrm{O}$ termo "cinema direto" é usado aqui se referir, de maneira geral, às diversas tendências incluídas nesta designação e, em particular, o cinema observacional americano e o cinema participativo de Jean Rouch. A referência está relacionada à série de características técnicas comuns aos diversos movimentos de vanguarda no documentário da década sessenta, como as câmeras $16 \mathrm{~mm}$ com som sincrônico, a câmera na mão, o som direto, as equipes reduzidas, etc.

${ }^{12}$ CINEMAIS, No. 22, p. 7-31.

${ }^{13}$ GALVÃO, BERNARDET, 1981, p.199.
} 
Farias e outros. O surto cresce e, por mais que sejamos visionários, afirmaremos que a cultura brasileira está entrando na idade do cinema, quando o velho mundo se consome no último pensamento da nouvelle vague (...)". ${ }^{14}$

Em São Paulo o impacto destes dois filmes acontece um pouco mais tarde, na Bienal de 1961, quando os documentários são exibidos na "Homenagem ao Cinema Brasileiro" - promovida por Bernardet e considerada por Glauber como o lançamento oficial do Cinema Novo em São Paulo. Ele afirma: "Além da homenagem, intenções polêmicas de grandes conseqüências. Num mesmo bloco (...) estouravam para o público-crítica paulista 'Arraial do Cabo', 'Aruanda' e 'Couro de Gato'; (....) esta semana teve para o novo cinema brasileiro a importância da Semana de Arte Moderna em 1922."15

É exatamente nesse momento histórico de renovação que começa a ser preparada a Caravana Farkas. Sua origem está ligada, evidentemente, à trajetória de Thomaz Farkas, seu idealizador e produtor. Húngaro de nascimento, Farkas chegou ao Brasil em 1930, com seis anos. Formou-se engenheiro, mas logo começou a trabalhar com fotografia na loja do pai e, na década de 40, já iniciava sua carreira como fotógrafo. No começo desta efervescente década de 60 , ele conheceu Fernando Birri e Edgardo Pallero, documentaristas argentinos centrais em sua trajetória. Birri realizou algumas conferências em São Paulo em 1963, e no mesmo ano Vladimir Herzog e Maurice Capovilla fizeram um estágio de três meses na Escola de Documentários de Santa Fé, fundada por ele na Argentina. A partir destes intercâmbios, articulou-se um grupo de jovens brasileiros, do qual Farkas fazia parte, em torno dos documentaristas argentinos e da Cinemateca Brasileira em São Paulo. Além de Farkas, Herzog e Capovilla, o grupo reunia também Lucila Bernardet e o argentino Manuel Horácio Gimenez. O que eles tinham em comum eram os desejos de realizar filmes sobre a realidade brasileira e de, segundo Thomaz

\footnotetext{
${ }^{14} \mathrm{O}$ artigo é citado pelo próprio Glauber em "Revisão Crítica do Cinema Brasileiro". Ver ROCHA, 2003, p. 125.

${ }^{15}$ ROCHA, Idem, p.130.
} 
Farkas, "tentar mostrar o Brasil aos brasileiros, que seria tão revolucionário por que ninguém conhecia o Brasil" ${ }^{16}$.

Na mesma época, Farkas se aproxima de Sérgio Muniz, Paulo Gil Soares e Geraldo Sarno - três jovens cineastas em início de carreira -, os futuros diretores de "A Condição Brasileira". Sérgio Muniz havia tido seu primeiro contato com o cinema, na década de 50, como assistente de câmera; mas começou de fato a trabalhar na área em 1963, atuando como diretor de produção de um filme de Rui Santos, "Os Corumbás", que acabou não se realizando. Depois desta experiência frustrada, trabalhou numa produtora de comerciais paulistana e, em 1964, freqüentando a Cinemateca, conheceu Thomaz Farkas. Geraldo Sarno, por sua vez, foi recomendado a Farkas por seu conterrâneo Glauber Rocha. Ela havia freqüentado o ICAIC Instituto Cubano de Arte e Indústria Cinematográficos -, o que lhe garantia uma certa prática cinematográfica. No início da década de 60 era um membro ativo do Centro Popular de Cultura (CPC), na Bahia. Suas primeiras experiências cinematográficas haviam sido realizadas com Orlando Senna e Valdemar Lima e eram mistos de documentário e ficção, de forte temática social.

Assim como Sarno, Paulo Gil Soares conectou-se ao grupo através do Cinema Novo. Seu primeiro encontro com Farkas aconteceu em 1964, no Rio de Janeiro, numa reunião para qual o fotografo havia convidado "as pessoas do dito Cinema Novo" ${ }^{17}$ para conversar sobre documentários. Farkas estava interessado em produzir documentários e tinha dinheiro para isso, mas, segundo Paulo Gil, a maior parte dos participantes do encontro viu sua proposta com reservas e classificou-o como um "paulista rico querendo promoção". Paulo Gil Soares - ao contrário dos outros participantes da reunião - acreditou na proposta de Farkas e, uma semana após este primeiro encontro, lhe entregou o roteiro de "Memória do Cangaço". O filme foi produzido no mesmo ano por Farkas, ao lado de outros três documentários, que, juntos, resultariam no longa-metragem "Brasil Verdade": "Subterrâneos do Futebol", dirigido por

\footnotetext{
${ }^{16}$ Ver CINEMAIS, n. 28, p. 13.

${ }^{17}$ MUNIZ, Sérgio (org), 1997, p. 09.
} 
Maurice Capovilla; "Nossa Escola de Samba", dirigido por Manuel Gimenez e "Viramundo" de Geraldo Sarno.

Maurice Capovilla lembra que a primeira reunião para discutir o projeto aconteceu na casa de Thomaz Farkas, no Guarujá, litoral de São Paulo, em abril ou maio de 1964. Além dos quatro diretores estavam presentes Edgardo Pallero - produtor executivo dos filmes - e Sérgio Muniz diretor de produção de "Viramundo". Capovilla afirma que "a motivação principal no início, do ponto de vista do Thomaz, era dar trabalho para um bando de cineastas desempregados e perseguidos, pois não há outra explicação para o fato de realizar tal projeto no clima conturbado e inseguro de implantação de uma ditadura". ${ }^{18}$

Os filmes foram produzidos ao longo de 1964 - dois em São Paulo e dois no Rio de Janeiro - e finalizados no início de 1965. Além de ser o produtor de todos os filmes, Farkas fotografou dois deles em conjunto com Armando Barreto - "Viramundo" e "Subterrâneos do Futebol" - e colaborou na fotografia (de Alberto Salvá Contel) de "Nossa Escola de Samba”. Já "Memória do Cangaço" foi fotografado por Affonso Beato, ligado ao grupo do Cinema Novo. Apesar de sua participação ativa no processo de realização, segundo Capovilla, Farkas não assumiu uma posição interferente como produtor, o que garantiu aos diretores uma grande liberdade formal. Em relação aos seus aspectos técnicos, os filmes inovavam ao incorporar o sistema de produção do cinema direto: câmeras $16 \mathrm{~mm}$ e som direto.

Cabe aqui um parêntese para contextualizar esta relação entre estes quatro documentários e o cinema direto. No início da década de 60 , ecos das novidades do cinema direto começavam a chegar ao Brasil. Isso porque - apesar da consolidação das diversas tendências do cinema direto no exterior - estes filmes ainda não eram exibidos por aqui. É só em 1962, que "Crônica de Um Verão" (1960), de Jean Rouch e Edgar Morin, é projetado pela primeira vez no país, no Rio de Janeiro, em uma semana dedicada ao cinema francês. Assim, foi de maneira indireta que os

\footnotetext{
${ }^{18}$ MUNIZ, Sérgio (org), 1997, p.11.
} 
cineastas brasileiros puderam entrar em contato com essa nova produção estrangeira e com os recursos aos quais ela estava ligada.

O ponto de inflexão na tomada de conhecimento sobre o direto foi o ano de 1962. Neste ano, aconteceu no Rio de Janeiro, promovido pela Unesco e pelo Itamaraty, o seminário do documentarista sueco Arne Sucksdorff, que apresentou o som direto aos cineastas brasileiros trazendo dois Nagras. O evento marcou o ponto de partida da importação das novas técnicas pelos realizadores brasileiros, que compareceram em peso. Estavam lá muitos diretores ligados ao movimento do Cinema Novo e algumas figuras do círculo de Farkas, como Lucila Bernardet e Vladimir Herzog.

Foi também em 1962, que Joaquim Pedro ganhou uma bolsa da Fundação Rockfeller para visitar os Estados Unidos, onde teve contato com os irmãos Maysles. Entusiasmado com as técnicas do cinema direto, na sua volta ao Brasil, tentou aplicá-las no documentário "Garrincha, Alegria do Povo". Entretanto, não conseguiu resolver tecnicamente o som direto, e o filme acabou recorrendo a narração em off da tradição griersoniana. No ano seguinte, Leon Hirszman deu mais alguns passos, utilizando algumas técnicas do direto em "Maioria Absoluta", assim como fez Saraceni em "Integração Racial". Ambos os filmes exploram o uso de entrevistas e das tomadas de improviso, apesar de ainda trabalharem com a narração expositiva. A partir daí, se popularizou o uso do som direto na produção documentária brasileira e em 1967, quando Arnaldo Jabor dirige "Opinião Pública", a técnica já estava completamente dominada.

Em sua tese, Farkas comenta o seminário de Sucksdorff e reconhece sua influência na produção brasileira no que diz respeito a procedimentos: "Os métodos precisam ser adaptados às realidades econômica e técnica brasileiras. Uso do filme, recursos, laboratórios, mão de obra especializada, equipamento". Farkas traça um panorama histórico que parte das atualidades do início do século e chega às experiências do cinema direto e do cinema verdade, onde os progressos técnicos permitem equipes menores e com maior mobilidade. Este novo cinema 
documentário, além de permitir que o realizador saia do estúdio e percorra as ruas captando sugestões "ao vivo", segundo Farkas, aproximaria o filme e o fato. Para ele, a experiência destas vanguardas foi a "base de todo o trabalho documentário atual para cinema e televisão"19.

Apesar do reconhecimento, por parte de Farkas, da importância destes movimentos e da defesa da incorporação de meios técnicos, seria precipitado apontar suas concepções sobre o documentário como diretamente tributárias da tradição do cinema direto. Em primeiro lugar, por falta de conhecimento. Vale considerar um depoimento de Farkas preservado na Cinemateca do MAM do Rio de Janeiro, no qual ele diz que, até começar as filmagens do "Brasil Verdade", não conhecia a tradição documental brasileira e sabia muito pouco sobre o cinema verdade ${ }^{20}$. Em segundo lugar, porque, de maneira geral, criou-se no Brasil dos anos 60 um interesse ligado aos aspectos técnicos do cinema direto do que propriamente à sua concepção. As inovações tecnológicas respondiam a uma demanda natural dessa nova geração de cineastas, considerando-se a precariedade de recursos do cinema brasileiro. No entanto, em termos teóricos, o documentário brasileiro não participava do debate envolvendo as diversas vertentes do direto.

Sobre a influência do direto no Brasil, o cineasta David Neves afirma: "Não se pode pensar ainda nos termos das discussões teóricas como, por exemplo, Marcorelles o fez ao falar da 'espontaneidade absoluta', de Leacock, da 'contestação dialogada, cara a Edgar Morin', e, mais aprofundamente, de 'fiction libératrice, comme chez Rouch' ou do 'événement révélateur (...) comme chez Perrault'. O que existe, verdadeiramente, é uma sensação progressiva de apreensão do fenômeno da comunicação, influenciado, é bem verdade pelos ecos (sobretudo pelos ecos - o que é um fato interessante) do êxito dos filmes análogos feitos no exterior"21.

\footnotetext{
${ }^{19}$ FARKAS, 1972, p.18 e 19.

${ }^{20}$ Este depoimento é citado por José Carlos Avellar. Ver MUNIZ, 1997, p.34. No mesmo sentido, ao traçar um panorama da história do documentário em sua dissertação, Farkas não cita nenhuma escola brasileira de documentário anterior à década de 60 .

${ }^{21}$ Ver artigo "A Descoberta da Espontaneidade - Breve Histórico do Cinema-Direto no Brasil", de 1966, reproduzido no número 39/40 da Revista Contracampo, 2002.
} 
Neste sentido, as discussões que fundamentam as diferenças entre o cinema direto americano e o cinema verdade de Rouch - como a contraposição entre a câmera observadora do primeiro e a câmera participativa do segundo - não têm repercussão no documentário brasileiro. Analogamente, os quatro curtas-metragens produzidos por Farkas em 1964 - citados tanto por David Neves como por Fernão Pessoa $\operatorname{Ramos}^{22}$ como os primeiros trabalhos paulistas a utilizarem técnicas do cinema direto - incorporaram à sua execução aspectos técnicos, como o som direto e as câmeras leves, sem se afastar de uma abordagem expositiva de representação da realidade.

Apesar de apresentarem grandes diferenças formais entre si, os documentários do "Brasil Verdade" compartilham a proposta de retratar criticamente a realidade brasileira e dialogam intensamente com um modo expositivo de representação. Como já apontado na introdução, o modo expositivo - que caracteriza estes documentários de cunho sociológico - está mais ligado, do ponto de vista formal, à tradição britânica de Grierson, do que ao documentário observacional ou participativo do cinema direto. É inclusive a partir da análise de dois curtasmetragens de "Brasil Verdade" que Jean-Claude Bernardet formula a categoria de "modelo sociológico" ${ }^{23}$.

O primeiro dos filmes a ser analisado ele é "Viramundo", apresentado por Bernardet como representante máximo da matriz sociológica, que acompanha a trajetória de trabalhadores rurais nordestinos que chegam a São Paulo. O filme é estruturado a partir de uma narração em off, que apresenta a situação do migrante através de dados e análises. Esta "voz do saber" se opõe à "voz da experiência" dos personagens, que ilustram a análise proposta pelo narrador e atestam sua veracidade: o trabalhador que deu certo, o trabalhador que não deu certo, os migrantes anônimos. Entre estas duas instâncias, está uma terceira voz, classificada por Bernardet de

\footnotetext{
${ }^{22}$ Ver RAMOS, 2004.

${ }^{23}$ As análises se encontram em BERNARDET, 2003, p. 15-58.
} 
"locutor auxiliar": o empresário. Apesar de, hierarquicamente, sua voz estar subordinada ao locutor, sua fala também é generalizante e colabora para a coesão do argumento. Além das seqüências relacionadas à indústria e ao emprego, o filme possui um segmento dedicado à religião em que, através dos exemplos de cerimônias de candomblé e protestantes, se demonstra seu caráter alienante.

Bernardet analisa também o curta-metragem "Subterrâneos do Futebol", enquadrando-o no "modelo sociológico", embora o filme apresente diferenças em relação ao esquema de "Viramundo". "Subterrâneos" aborda a situação do futebol em 1964, acompanhando a relação dos torcedores com o esporte; mostrando jovens que sonham com a glória; astros em ascensão; e jogadores em declínio. Além de uma locução expositiva, o documentário trabalha com depoimentos de jogadores, torcedores, técnicos e dirigentes. A partir destes elementos, constróise um discurso que critica o uso do jogador como mercadoria e o futebol como válvula de escape para a população. Entre as diferenças principais em relação à "Viramundo", destacadas por Bernardet, está o fato de o mecanismo particular/geral acontecer, em "Subterrâneos", de maneira menos perfeita. Isto é, uma vez que os jogadores em questão não são anônimos e por diversas razões se destacam, suas experiências nem sempre são passíveis de generalização.

A entrevista também é um dos recursos fundamentais de "Memória do Cangaço", que aborda o cangaço a partir do material de arquivo sobre os cangaceiros, filmado pelo mascate Abraão Benjamim, na década de 30. Paulo Gil Soares entrevistou ex-cangaceiros e o ex-policial Zé Rufino, matador de cangaceiros (que inspirou Antônio das Mortes de "Deus e o Diabo"). Mais uma vez, observa-se a presença ordenadora na narração em off, que dialoga e baliza os testemunhos dos personagens. Já em "Nossa Escola de Samba”, a narração é conduzida por um locutor - que assume o ponto de vista de China, um dos dirigentes da escola Unidos de Vila Isabel -, e os depoimentos são suprimidos. O documentário mostra a preparação da escola de samba para um desfile de carnaval. Partindo do dia do desfile, o documentário articula uma cronologia da preparação que se dá em grandes saltos: seis meses antes do desfile; dois meses 
antes do desfile; a tarde anterior ao desfile; o desfile; e o dia seguinte, mostrando a volta da comunidade ao cotidiano. Embora em "Nossa Escola" o narrador não exponha um argumento, ele nos impõe uma perspectiva definida diante da realidade apresentada.

Além de seu evidente caráter expositivo, é possível notar nestes quatro filmes a ausência de procedimentos recorrentes no cinema direto. Em relação ao cinema observacional americano as diferenças são evidentes, levando-se em conta características apontadas por Nichols ${ }^{24}$ como: a opção por registro diálogos não dirigidos para a câmera; a recusa de entrevistas; e a ausência de comentário. Mesmo se comparados ao cinema de Jean Rouch - que aceita, por exemplo, o uso da entrevista - as diferenças são nítidas. A noção de que a câmera deve funcionar como uma catalisadora da relação entre diretor e protagonistas e a idéia de que os acontecimentos e personagens não pré-existem ao filme, não se aplicam de maneira geral aos documentários do "Brasil Verdade". Neves insere, no final de seu texto, um relato escrito por Edgardo Pallero, produtor executivo destes quatro filmes, que enfatiza a questão da estratégia de produção dos trabalhos. Ele ressalta o rigor industrial que caracterizou a experiência e o fato de eles levarem em conta, com igual importância os aspectos artístico e econômico do trabalho. Mais adiante Pallero afirma: "É importante esclarecer que não nos propusemos de início a fazer um cinema documental enquadrado nos cânones do que comumente se chama de cinema-verdade; o que se queria era fazer uma obra autêntica comprometida e útil para uma maior compreensão dos fenômenos culturais por ela abarcada"25.

Apesar de seu distanciamento formal do que seria a vanguarda documentária da época, os filmes, lançados separadamente em 1965, obtêm repercussão dentro e fora do Brasil. "Memória do Cangaço", por exemplo, ganha a Gaivota de Ouro do Festival Internacional do Filme de 1965, no Rio de Janeiro. A partir daí, além de participar de vários festivais, os documentários também foram exibidos em circuitos alternativos, como conta Muniz: "Eu pessoalmente cheguei a fazer

\footnotetext{
${ }^{24}$ Ver NICHOLS, 1991.

${ }^{25}$ NEVES, 1966.
} 
mais de 60 apresentações em São Paulo, de casa em casa, de sindicato em sindicato, quando era possível. Enfim, foi um momento de grande importância na conformação do que a gente queria fazer que era cinema". ${ }^{26} \mathrm{Em}$ 1967, os documentários foram ampliados para 35mm e reunidos na versão de longa-metragem para a exibição em cinema comercial que teve o título de "Brasil Verdade". ${ }^{27}$

\section{PREPARAÇÃO DE "A CONDIÇÃO BRASILEIRA"}

Com a repercussão internacional de "Brasil Verdade", Thomaz Farkas fez um acordo com a produtora do documentarista francês Pierre Kast para a produção de uma série de quatro documentários sobre cultura brasileira para a televisão francesa intitulada "Carnets Brésiliens", dirigida por Kast. Com isto, Farkas criou o princípio de uma rede internacional de relações. Por outro lado, desenvolveu também uma parceria com o Instituto de Estudos Brasileiros da Universidade de São Paulo que, graças ao apoio do crítico Paulo Emílio Salles Gomes e da socióloga Maria Isaura Pereira de Queiroz, havia organizado um Departamento de Produção de Filmes Documentários, ao qual o grupo de Farkas - em especial Sérgio Muniz e Geraldo Sarno estava ligado. O departamento facilitava a produção, emprestando fitas, doando negativos e fornecendo transporte, entre outras coisas.

Um dos primeiros frutos dessa parceria foi "O Povo do Velho Pedro", um documentário de caráter sociológico, dirigido em 1967 por Sérgio Muniz ${ }^{28}$ e captado em Santa Brígida, uma cidade do norte da Bahia. O filme foi produzido com o apoio do IEB e do CERU (O Centro de Estudos Rurais e Urbanos, também ligado a USP) e retrata uma comunidade messiânica, de Santa Brígida, estudada por Maria Isaura Pereira de Queiroz. O trabalho contou com uma equipe interdisciplinar da USP - com um sociólogo, um antropólogo, um geógrafo, um

\footnotetext{
${ }^{26}$ MUNIZ, Sérgio (org), 1997, p.05.

${ }^{27}$ Os filmes haviam sido captados em $16 \mathrm{~mm}$, com exceção de "Memória do Cangaço" que havia sido filmado originalmente em $35 \mathrm{~mm}$.

${ }^{28}$ O filme seria dirigido por Paulo Gil Soares, que teve um contratempo e não pode viajar, sendo então assumido por Muniz.
} 
economista e um psicólogo -, que ficou um mês na cidade. Durante esta estadia, Sérgio Muniz conheceu Seu Batista, a quem, em 1968, usaria como personagem em dois documentários de “A Condição Brasileira": "Rastejador" e "Beste". Segundo Muniz, após "O Povo do Velho Pedro" criou-se uma dinâmica de grupo: Thomaz Farkas, IEB, CERU, Sérgio Muniz, Geraldo Sarno, Paulo Rufino e Francisco Ramalho.

O passo seguinte do grupo foi, ainda em 1967, realizar uma viagem de carro pelo Nordeste. Thomaz Farkas, Paulo Rufino e Geraldo Sarno participaram desta experiência que definiu, além da própria Caravana Farkas, a pauta cinematográfica de Sarno - segundo ele mesmo - pelos quinze anos seguintes. Apesar de nenhum dos três estar ainda sob contrato, a viagem não foi apenas de investigação, mas também de captação de imagens, posteriormente aproveitadas por filmes da Caravana. Eles levaram uma câmera $16 \mathrm{~mm}$, um gravador Nagra, e uma câmera fotográfica. Farkas bancou os gastos de alimentação e hospedagem, e fotografou. O roteiro desta expedição prefigurou, de certa forma, o que eles fariam no ano seguinte, apontando uma série de parcerias e conexões que tiveram alta relevância para a produção da Caravana.

Partindo de São Paulo, eles passaram pela Bahia e por Alagoas, chegando a Pernambuco. ${ }^{29}$ Antes do início da viagem, Sarno havia assistido no IEB algumas conferências do professor de literatura Cavalcanti Proença, sobre cultura popular oral, e pediu a ele algumas indicações de pessoas no Nordeste. Entre os nomes que Proença indicara estavam os cantadores Severino Pinto e Lourival Batista. Severino Pinto morava em Caruaru (PE) e foi localizado pela equipe. Através de um anúncio na rádio, contataram também Lourival Batista, e agendaram uma cantoria com os dois no sertão da Paraíba. Este encontro foi registrado e o material gerou o curta-metragem "A Cantoria"; dirigido por Sarno e dedicado a Proença. A documentação que realizaram na região de Caruaru resultou também no curta-metragem "Vitalino/Lampião"

\footnotetext{
${ }^{29}$ Sarno deu seu testemunho sobre a viagem em um debate promovido pelo Festival É Tudo Verdade (2000) e posteriormente transcrito pela revista Cinemais. Ver CINEMAIS, No. 28, p.7-39.
} 
(1969), que acompanha o trabalho de Vitalino, um ceramista artesanal que produzia imagens de Lampião.

O grupo seguiu então viagem para a Paraíba e, em João Pessoa, encontrou Linduarte Noronha, uma influência declarada de todos os participantes da Caravana. No sertão paraibano, filmaram três cegas na feira de Campina Grande e visitaram a folhetaria Estrela da Poesia, onde registraram o processo de composição, impressão e xilogravura. Subiram para o Rio Grande do Norte, passaram pelo Ceará e desceram para o Vale do Cariri, onde permaneceram algumas semanas. Em Juazeiro, conheceram o mestre imaginário ${ }^{30}$ Noza e filmaram seu processo de fabricação de imagens do Padre Cícero; além de registrar outras atividades artesanais e manifestações culturais da cidade. Sarno esperava realizar um documentário com o extenso material captado por eles sobre as oficinas artesanais de Juazeiro. Do seu ponto de vista, Juazeiro era uma cidade medieval, "porque a indústria, a forma industrial de produção realmente não tinha chegado, e era um centro de produção artesanal que abastecia todo o sertão" ${ }^{31}$. O projeto foi frustrado pela danificação dos negativos na montagem, mas o interesse de Sarno persistiu e resultou - dois anos mais tarde - em "Viva Cariri!", filme que apresenta Juazeiro como uma síntese do sertão.

Segundo Geraldo Sarno, em termos de captação, o saldo final desta primeira incursão nordestina da Caravana foi a produção de quatro documentários: "Vitalino/Lampião" (1969), "Jornal do Sertão" (1970) - que fala sobre o papel da literatura de cordel - "Os Imaginários" (1970) - sobre artesãos que fazem imagens de madeira em Juazeiro - e "Eu Carrego um Sertão Dentro de Mim", realizado a partir de uma entrevista de Guimarães Rosa, coberta por imagens do sertão. Os cálculos de Sarno, entretanto, são parcialmente contraditos pelas fichas técnicas dos filmes. As fotografias de "Os Imaginários" e "Jornal do Sertão", por exemplo, são de Affonso Beato, que não estava presente nesta etapa preparatória. Além disso, a ficha técnica divulgada na

\footnotetext{
${ }^{30}$ Artesão que produz imagens em madeira.

${ }^{31}$ CINEMAIS, No. 28, p. 24.
} 
mostra "A Caravana Farkas" - que não incluiu o filme "Eu Carrego Um Sertão Dentro de Mim" - indica que os três primeiros documentários foram finalizados entre 1969 e 1970, no mesmo período daqueles captados durante a expedição propriamente dita. ${ }^{32}$

Independentemente de seus resultados, esta primeira missão de reconhecimento pelo sertão nordestino - onde coisas foram vistas; pessoas foram localizadas e contatadas - pautou a segunda fase do projeto, realizada num outro formato de produção, mais articulado e organizado. Os diretores aproveitaram desta primeira etapa, além do levantamento de temas, descobertas em relação a locações e personagens, tais como mapas detalhados de diversas feiras nordestinas, com indicações precisas do que havia - artesões, cantadores, etc - nas ruas de cada uma delas.

\section{FASE 02: "A CONDIÇÃO BRASILEIRA"}

A decisão de Thomas Farkas de produzir em 1968 os documentários de "A Condição Brasileira" estava relacionada com sua crença de que estes filmes seriam viáveis em termos mercadológicos. Sua idéia inicial era distribuir estes documentários no mercado de filmes didáticos, que parecia bastante promissor na década de 60. Segundo Sérgio Muniz, na época, entre 1000 e 1200 escolas no Brasil possuíam projetores $16 \mathrm{~mm}$, e destas, aproximadamente 250 podiam comprar filmes e, com freqüência, pediam filmes sobre o Brasil. Entretanto, com o AI-5, as escolas passaram a não poder mais cobrar por atividades extracurriculares e deixaram de adquirir filmes, frustrando os planos de Farkas. O produtor imaginava também que - sendo este projeto auto-sustentável economicamente - a documentação da região Nordeste, poderia ser estendida para outras regiões brasileiras; o que, com o fracasso comercial deste primeiro conjunto, acabou não se realizando.

\footnotetext{
${ }^{32}$ Por estas razões, contrariando o testemunho de Sarno, incluí "Vitalino/Lampião", "Jornal do Sertão" e "Os Imaginários" na contagem de 20 filmes de "A Condição Brasileira”.
} 
De qualquer forma, o Nordeste era a escolha mais natural para a primeira etapa, tendo em vista os contatos prévios estabelecidos por Farkas e Geraldo Sarno durante a viagem de 1967, e todo o contexto político e cultural do momento. Tratava-se do verdadeiro Brasil a ser revelado, como colocado por Farkas.

Sarno, por exemplo, ao falar sobre a enorme influência que a passagem de Lina Bo Bardi pela Bahia no começo da década de 60 teve em seu trabalho diz: "ela foi a pessoa que me revelou, através do museu de Arte Popular da Bahia, que junto à miséria, à pobreza econômica que havia no sertão nordestino, havia uma riqueza cultural absolutamente extraordinária". Outra referência apontada por Sarno, ligada ao interesse pela temática da cultura popular nordestina, é o documentário "Aruanda", de Linduarte Noronha, descrito por ele como uma revelação total, que lhe permitiu projetar a idéia de fazer cinema. Para ele, "Aruanda" revelava que: "aquele meu mundo da infância e da juventude no sertão era cinematografável, podia estar nas telas de cinema". ${ }^{33}$

Estas afirmações vão ao encontro de colocações de Farkas em sua tese de doutorado ${ }^{34}$, na qual afirma que o foco temático do documentário brasileiro deveria ser: o regional, o primitivo, o folclore e a religiosidade. Isto não significava simplesmente registrar estas manifestações. Para Farkas, o que deveria ser buscado, através da documentação das manifestações exteriores, era a revelação da verdadeira origem das relações que as determinam. Do seu ponto de vista, o que estava em jogo era a captura de tradições e de um modo de vida fadados a acabar e, que, por isso mesmo, se encontravam numa situação de conflito rara. Neste sentido, ele afirma: "Existem inúmeros núcleos remanescentes de um modo de vida rudimentar e primitivo ao lado de cidades de complexa estrutura sócio-econômica, regiões que não foram atingidas pela penetração da civilização tecnológica e outras que vêm sofrendo o 'ataque' benéfico de um

\footnotetext{
${ }^{33}$ CINEMAIS, n. 28, p.36.

${ }^{34}$ Ao longo do trabalho levei a teorização de Farkas em conta como um dado relevante do que era sua visão sobre documentário no período aproximado de realização de filmes da Caravana (64-69). Para justificar essa leitura, considerei não apenas a data de publicação do trabalho, que é 1972, como também o fato de sua dissertação pretender de certa forma sintetizar seu método de trabalho como produtor de documentários desde "Brasil Verdade" até "A Condição Brasileira".
} 
progresso que traz novas contradições e novos problemas". ${ }^{35} \mathrm{O}$ que interessa a Farkas são as "ilhas culturais", que preservavam uma tradição oral e costumes pouco influenciados pelo progresso industrial. Mais do que uma oportunidade, o documentarista teria, em relação a estes núcleos culturais dos quais o sertão nordestino fazia parte, uma missão: "O difícil acesso a estes núcleos dá ao documentarista um papel de grande urgência e relevância". ${ }^{36}$

Sérgio Muniz demonstra também, em depoimentos posteriores a Caravana, uma grande preocupação em relação a questões levantadas por Farkas, tais como a preservação da cultura popular nordestina e a manutenção dos aspectos regionais e do linguajar. Neste sentido, para ele, este novo documentário brasileiro que surgia na década de 60 nutria-se das mesmas raízes que filmes do Cinema Novo, tais como "Vidas Secas" e "Deus e o Diabo na Terra do Sol". Segundo ele, se tratava de "uma descoberta do Brasil verdadeiro". ${ }^{37}$

Ao longo da década de 60, o conceito de "autenticidade" na cultura nacional estava em pleno centro do debate em várias áreas da cultura, incluindo a do cinema. Para a construção de um "estilo nacional" seria importante recuperar o que era considerado autenticamente nacional, e era bastante comum associar o autêntico ao Brasil rural, em especial o da região Nordeste, e não ao Brasil urbanizado e cosmopolita. No sertão, os problemas nacionais estavam radicalmente colocados, sendo fonte riquíssima para filmes muito comprometidos com a temática social, como se observa na primeira fase do Cinema Novo. Ao lado da preocupação temática, existia também uma preocupação formal em relação a estes elementos culturais característicos do verdadeiro Brasil ameaçado. O Cinema Novo, por exemplo, na tentativa de criar um "cinema popular", buscava incorporar elementos da cultura popular. Ou seja, constituir-se como um cinema que se legitima enquanto arte popular, re-elaborando criticamente os dados brutos da

\footnotetext{
${ }^{35}$ FARKAS, 1972, p. 19.

${ }^{36}$ Idem

${ }^{37}$ CADERNOS DE RTV / 01
} 
cultura popular alienada. Através desse procedimento, o "cinema popular" deveria ser capaz de atingir o povo e gerar consciência. ${ }^{38}$

Como será visto adiante, o procedimento de apropriação crítica de elementos da cultura popular - calcado no registro do fazer do homem nordestino - é muito presente também na Caravana Farkas, embora estes documentários não me pareçam engajados na busca de um diálogo com os extratos sociais por eles retratados. Os filmes da Caravana aparentemente se dirigem a um público próximo do universo cultural de seus realizadores; isto é, à classe média intelectualizada e com um posicionamento ideológico de esquerda. Os documentários buscavam mostrar uma certa realidade brasileira para aqueles que não pertenciam a ela, e a partir da exposição crítica da miséria fomentar o debate político.

É dentro deste contexto em que são centrais as questões da preservação cultural e da revelação de uma Brasil autêntico, que a pré-produção propriamente dita de "A Condição Brasileira" tem início. De junho de 1968 a março de 1969, Sérgio Muniz e Ana Carolina trabalharam na pesquisa de temas possíveis e de bibliografia de apoio para os filmes. Eles contavam com a ajuda de Geraldo Sarno e Paulo Gil Soares, indicando possíveis assuntos e apoios logísticos no Nordeste.

Sérgio Muniz descreve o trabalho de pré-produção da seguinte forma: "Fomos levantando o que era possível documentar ao longo de um ano inteiro, dependendo da época; janeiro tem não sei o quê com cana-de-açúcar, não sei quando tem mandioca, não sei quando tem milho, tem festas religiosas, enfim (...) fizemos um grande levantamento, levamos seis meses para fazer isso; no final de 68 o Farkas arrebanhou recursos, conseguiu comparar uma moviola, uma outra câmera Eclair, Nagra, refletores, filmes, comprou uma perua C-14, pôs uma plataforma em cima, enfim,

\footnotetext{
${ }^{38}$ A evolução do debate sobre o nacional e o popular no cinema brasileiro até a década de 80 é amplamente discutida por Maria Rita Galvão e Jean-Claude Bernardet, em "O Nacional e o Popular na Cultura Brasileira". Os autores examinam detalhadamente o debate entre os Centros Populares de Cultura e os representantes do Cinema Novo, polêmica que não irei discutir neste momento. VER GALVÃO, BERNARDET, 1981.
} 
o mínimo de produção, e conseguimos um acordo, acho que foi com a Ford até, de ter um segundo veículo emprestado para a produção ir na frente, levantando as condições de produção." ${ }^{39}$ No final de 1968 Edgardo Pallero - que havia sido o produtor executivo dos quatro documentários do "Brasil Verdade" - juntou-se ao grupo, dando início aos últimos preparativos do período de captação: a importação de equipamentos e latas de filmes; a elaboração da programação do dia-a-dia de viagens; a definição de hospedagem, locações e do plano de filmagem; e a logística financeira para a execução do trabalho.

As filmagens aconteceram entre março e maio de 1969 e, ao longo destes três meses, a equipe tinha como meta captar material suficiente para a realização de dez documentários. Ao final da viagem, as expectativas foram superadas e, somando os materiais captados em 1967 e o resultado das filmagens de 1969, foram realizados 19 documentários: nove filmes de Geraldo Sarno ${ }^{40}$, seis de Paulo Gil Soares ${ }^{41}$, e quatro de Sérgio Muniz ${ }^{42}$. O vigésimo filme foi "Herança do Nordeste", a compilação que reuniu cinco documentários da série - "Padre Cícero", "Jaramataia”, “Casa de Farinha”, “A Erva Bruxa” e "Rastejador” - numa versão longa-metragem em 35mm para exibição comercial.

Os documentários foram realizados em sistema de rodízio. A primeira leva foi produzida por Geraldo Sarno no interior do Ceará e Pernambuco; a segunda por Paulo Gil Soares, na Paraíba e no Recôncavo Baiano; e a terceira por Sérgio Muniz, no interior da Bahia. A produção executiva era feita por Edgardo Pallero e Muniz, que chegavam às locações sempre antes do resto da equipe. Em relação à organização de trabalho da Caravana, a tese de Farkas é muito informativa, já se baseia em sua própria experiência de trabalho. A tese é acompanhada inclusive de um

\footnotetext{
${ }^{39}$ Site Mnemocine

40 "A Cantoria" (14', 1970), "Casa de Farinha" (13', 1970), "Jornal do Sertão" (13', 1970), "O Engenho" (09’30", 1970), "Os Imaginários" (10’, 1970), "Padre Cícero" (10’, 1971), "Região: Cariri” (10’, 1970), "Vitalino Lampião" $(09$ ', 1969) e "Viva Cariri!" (36', 1970).

41 "A Mão do Homem” (18’, 1969-1970), "A Morte do Boi” (10’, 1970), "A Vaquejada" (10’, 1970), "Frei Damião: Trombeta dos Aflitos, Martelo dos Hereges" (20', 1970), “Jaramataia” (20', 1970), "O Homem de Couro” (20', 1970).

42 “Beste” (20’, 1970), “A Erva Bruxa” (20', 1969-70), “De Raízes e Rezas, entre outros” (37’, 1972), "Rastejador, s.m.” $(25,1970)$.
} 
dossiê fotográfico, que tem a intenção de ilustrar o modo de fazer exposto por Farkas, no qual estão retratadas as filmagens de diversos documentários de "A Condição Brasileira”.

De acordo com Farkas, os primeiros passos para a execução de um documentário deveriam ser: a busca de dados sobre o assunto em questão, para preparação do roteiro; e o levantamento de informações de produção, tais como locações, vias de acesso, hospedagem, etc. Esta "cobertura científica ampla" garantiria a exeqüibilidade do documentário.

Farkas faz uma defesa clara da necessidade do roteiro prévio - que acredito ter sido uma opção efetiva na realização dos filmes da Caravana -, embora afirme que o diretor deve ser flexível para lidar com as diferenças entre o previsto e o encontrado. Ele defende também o uso de equipes pequenas - o que é consistente com a prática de "A Condição Brasileira" - para garantir a viabilidade financeira dos projetos, a partir de um princípio de multiplicidade de funções. Ou seja, dentro do que seria a equipe mínima - pesquisa/roteiro/direção/montagem; imagem; som; assistente de produção e coordenação de projeto -, uma mesma pessoa poderia exercer mais de uma função, reduzindo a equipe a dois ou três elementos. Na concepção de Farkas o diretor teria de organizar uma estrutura dramática a partir dos fatos, buscando revelar uma síntese do que observa.

Embora o método de produção não seja relevante para a análise que será feita a seguir dos filmes, em termos históricos, ele é da maior importância. Vários dos participantes, ao se referirem a esta segunda fase de captação, chamam atenção para o fato de que se tratava de uma iniciativa inédita no Brasil. Para Sérgio Muniz "nunca houve um esforço de produção com estas características antes e nunca houve depois" ${ }^{43}$. Paulo Gil Soares dá um depoimento no mesmo sentido: "... e lá fomos nós realizar um ciclo fantástico de filmes que retratava a cultura da região, num esforço de produção que nunca mais se repetiu e acredito ser difícil voltar a acontecer". ${ }^{44}$

\footnotetext{
${ }^{43}$ CADERNOS DE RTV/01

${ }^{44}$ MUNIZ, Sérgio (org), 1997, p. 09.
} 
De fato, uma produção em série nesses moldes - sem compromisso comercial, sem apoio de uma rede de televisão e valorizando a liberdade máxima de realização - me parece ímpar na história do documentário brasileiro.

A partir do levantamento inicial de temas, os diretores - segundo seus próprios depoimentos tinham uma grande liberdade para definir os enfoques específicos de cada um de seus documentários e, posteriormente, para a realização dos mesmos. Contribuindo para essa liberdade de execução estava, segundo Sarno, o fato de que os diretores não tinham - no momento de sua realização - muita clareza sobre qual seria o público destes documentários. Ainda que Farkas pretendesse vendê-los, não havia um cliente objetivo imediato, nem se tratavam de documentários para a televisão. Com isso, não estava colocada a preocupação com o espectador em potencial, nem com o enquadramento dos materiais captados em formatos específicos. Não existia, por exemplo, uma duração pré-determinada para os filmes. ${ }^{45}$

O resultado disso foi uma produção bastante heterogênea, na qual se notam particularidades evidentes dentre os conjuntos de filmes de cada um dos diretores; conforme será mostrado nos capítulos seguintes. De maneira geral, observa-se ainda nos filmes de "A Condição Brasileira" uma filiação ao chamado "modelo sociológico", embora as estratégias de organização do material fílmico tenham mudado bastante em relação ao "Brasil Verdade". Neste sentido, ocorre uma aproximação do cinema direto, maior do que o puro empréstimo de meios técnicos. Como as análises procurarão demonstrar em mais detalhe, os documentários analisados combinam uma grande variedade de procedimentos: a entrevista, a narração em off, e também imagens captadas a partir de estratégias observacionais. Os filmes trabalham, invariavelmente, com núcleos observacionais de imagem que podem ser combinados de diferentes formas com a banda sonora, mas que, de maneira geral, criam um aumento do "efeito verdade" buscado com ênfase pelo documentário direto norte-americano.

\footnotetext{
${ }^{45}$ Sem um mercado definido, os filmes acabaram tendo uma circulação pequena e permanecem até hoje bastante desconhecidos, mesmo no circuito especializado. A exibição na época se deu em circuitos alternativos - como faculdades e escolas - e de forma amadora.
} 
Por outro lado, os filmes - se analisados de maneira global - não trabalham com um baixo nível de afirmação da voz do texto, como se vê freqüentemente na tradição observacional norteamericana. Para Farkas, assim como para os realizadores, tinha enorme importância a idéia de que o documentário deveria expressar uma visão clara e nítida do autor em relação à realidade observada. Em outras palavras, o que se vê é uma preocupação em afirmar claramente a voz do texto; o que, de fato, se reflete na produção. Muniz, por exemplo, destaca que os documentários de "A Condição Brasileira" se propunham a apresentar "uma visão pessoal e particular" 46 , e aponta o trabalho de Joris Ivens - que assumia uma posição política clara diante de acontecimentos históricos - como uma referência desta postura documentária.

Assim, intencionalmente ou não, os filmes ainda são tributários - e a referência a Joris Ivens é sugestiva neste sentido, uma vez que ele, tanto quanto Grierson, é apontado como ícone do modo expositivo - do documentário britânico da década de 30. Além das características que podem ser destacadas a partir dos esquemas expositivos dos próprios filmes, a definição de Farkas de documentário é bastante reveladora desta relação. Para ele, o documentário é uma forma de representação do real que, a partir do movimento e da palavra, tem poder de persuasão. Em sua tese, ele destaca conceitos griersonianos como as idéias de que o documentário é uma interpretação criativa da realidade, e que as relações sociais são fundamentadas por esquemas dramáticos.

Ainda dentro da discussão sobre o programa teórico subjacente ao projeto da Caravana Farkas, José Carlos Avellar cita um depoimento de Thomaz Farkas, de 1971, concedido a Alex Viany na apresentação de "A Condição Brasileira". Ao se referir a "Viva Cariri!", Farkas disse preferir um documentário em que "as coisas são ditas não pelas pessoas entrevistadas, mas pela construção dramática do filme". Neste sentido, Avellar atribui às preocupações da série um lastro duradouro: "As preocupações de então, construir uma dramaturgia cinematográfica capaz de

${ }^{46}$ CADERNOS DE RTV. 01 
montar uma imagem crítica da realidade, mostrar a realidade tal como sentida e pensada pela subjetividade do realizador no instante concreto da filmagem, não reduzir o documento ao simples registro objetivo da câmera, usar a parte, aquele particular pedaço de país filmado para revelar o todo, (...) as preocupações de então orientaram boa parte do cinema documentário feito nas décadas seguintes". ${ }^{47}$

Embora reconheça a importância histórica desses trabalhos e admita que seu princípio norteador possa estar relacionado à produção documentária brasileira que se seguiu, discordo de Avellar a respeito de seu caráter de ponto de partida. Como as análises dos capítulos seguintes tentarão mostrar, os filmes de "A Condição Brasileira" se colocam como elementos de transição dentro de uma trajetória de transformação do documentário brasileiro ${ }_{2}$ que parte do documentário expositivo de cunho sociológico da primeira metade da década de 60 , em direção a trabalhos onde os limites da representação fílmica passam a ser discutidos mais concretamente, e a "voz do outro" pode ser ouvida com mais clareza.

${ }^{47}$ Idem 


\section{CAPÍTULO 02 | "VIVA CARIRI!" E A FRAGMENTAÇÃO COESA DE SARNO}

A primeira das três análises fílmicas que compõe o núcleo central deste trabalho aborda "Viva Cariri!" (37 minutos, 1970), um dos nove documentários dirigidos por Geraldo Sarno na Caravana Farkas. O filme se destaca do restante de sua produção na Caravana por ser o único média-metragem. Os outros oito curtas-metragens dirigidos por ele - "A Cantoria” (1970), “Casa de Farinha” (1969-1970), “O Engenho” (1970); "Padre Cícero” (1971), “Região: Cariri” (1970), “Jornal do Sertão” (1970), “Os Imaginários” (1970) e “Vitalino Lampião” (1969) podem ser classificados como monografias. Com durações entre 09 e 14 minutos, cada um deles enfoca um aspecto bastante específico da cultura popular nordestina: um desafio de cantadores (“A Cantoria"), a produção de mandioca em uma casa de farinha ("Casa de Farinha"), o processo de produção de rapadura em um engenho (“O Engenho”) e assim por diante.

Além de ser mais longo que estes filmes, "Viva Cariri!" era declaradamente o maior foco de interesse de Sarno. Para ele, o importante nestas curtas monografias era ganhar condições economizando filme e tempo de filmagem - para realizar um documentário de maior profundidade sobre o Nordeste, que viria a ser "Viva Cariri!". Ao perceber que seria impossível abranger todo o universo sertanejo, escolheu enfocar a região de Juazeiro, no Cariri, considerada por ele uma síntese - cultural, econômica e populacional - do sertão. No filme, Geraldo Sarno contrapõe uma Juazeiro mística a uma Juazeiro econômica, relacionando aspectos da religiosidade local a seu processo de desenvolvimento. De maneira mais complexa, ele retoma conteúdos e idéias que aparecem nas monografias.

Do ponto de vista econômico, por exemplo, o filme mostra a frustração do projeto de desenvolvimento industrial da região e a decadência das oficinas artesanais - premissa recorrente nas monografias. Ao tratar da religiosidade local, construída em torno da figura mítica de Padre Cícero, faz-se notar um olhar bastante crítico, sugerindo relações estreitas entre fé e alienação; política e religião. 
Ao comentar "Viva Cariri!", a posteriori, Geraldo Sarno ressalta que, em termos de estrutura e de linguagem, pretendia fazer algo completamente diferente de "Viramundo": "eu queria me libertar da câmera e eu consegui me libertar da câmera! No Viva Cariri! eu me liberto da câmera. Eu tinha isto como proposta de criação: eu tenho que sair da câmera! No Viramundo eu estava preso à câmera". ${ }^{48}$

Segundo Sarno, enquanto a montagem de "Viramundo" é caracterizada pela linearidade, em "Viva Cariri!" sua opção foi por uma montagem que ele classifica como "tipo mosaico", se referindo ao que acredita ser um modo de organização do material fílmico menos linear. Ele explica que procurou estruturar o tema da economia de Juazeiro a partir de três seqüências: pequenas propriedades, artesanato e indústria. Apesar desta esquematização, Sarno acredita que a estrutura do filme é bastante fragmentária ou, como ele classifica, "uma forma vazia, espacial, um desenho vazio e que, sendo documentário, você vai buscar as imagens possíveis, e vai não encaixando a forma, porque na medida que você consegue captar imagens essas imagens também transformam, modificam, conformam essa forma vazia..."49

De fato, as diferenças entre os dois filmes são várias e significativas. Enquanto "Viramundo", realizado em 1964, pode ser considerado o documentário símbolo do que se convencionou chamar de "modelo sociológico", "Viva Cariri!" revela algum distanciamento em relação às características comuns a documentários identificados com este "modelo", em especial no que diz respeito a um certo modo de olhar a realidade brasileira.

Isso se deve em primeiro lugar a uma mudança radical no contexto de produção. Em 1968, não apenas o golpe militar já havia acontecido como, a partir do AI-5 e do recrudescimento da ditadura militar, o intelectual de esquerda precisou elaborar o fracasso de um projeto de

\footnotetext{
${ }^{48}$ CINEMAIS. Número 28. p.26

${ }^{49}$ Idem
} 
oposição e repensar suas estratégias de ação. A esperada revolução não se confirmara e a esquerda precisou encontrar novas respostas para lidar com a frustração da derrota.

Em termos culturais o cenário também é outro. A discussão em relação à arte didática e popular, que se desenvolveu ao longo de toda a década de 60 , foi colocada em cheque pelo Tropicalismo em 68, que trouxe experimentação formal, humor e ironia para a cultura popular, escancarando o diálogo com a industria cultural e a cultura de massa. Se 1964 é o ano de "Deus e o Diabo na Terra do Sol” e de sua teleologia da revolução, em 1967 “Terra em Transe” busca elaborar dramaticamente o golpe militar. O diagnóstico preciso e as determinações irrevogáveis do dito documentário sociológico da primeira metade da década têm que ser revistos. A análise de fundo sociológico ainda está presente, apontando contradições políticas e sociais do Nordeste, mas as soluções estão indicadas com menos nitidez.

A década de 70 marca a passagem da "voz do dono" para a "voz do outro". Surgem documentários que rompem com a voz sociológica - autoritária e onisciente - e buscam um olhar interno à realidade observada, que questionam os limites da representação da cultura popular. A relação sujeito/objeto, que caracterizava o modo que grande parte dos cineastas se colocava diante da cultura popular, é substituída por outra, mais horizontal, em que o embate entre cineastas e cultura popular passa a ser um diálogo entre dois sujeitos. A presença dos cineastas e seu papel de mediação começam a ser assumidos e alguns documentaristas chegam mesmo a colocar a câmera nas mãos deste “outro".

$\mathrm{Na}$ mesma época observa-se o início de uma mudança no olhar do cinema brasileiro em relação à religião, que está esboçada em "Viva Cariri!". Se em "Viramundo" a religião é protestante, retratada em sua dimensão pública, e perversa, por funcionar como mecanismo de condensação das frustrações sociais, em "Viva Cariri!" ela é abordada com mais nuances. Ao lado do aspecto 
exterior da religião, começa a surgir um espaço para a experiência subjetiva da fé ${ }^{50}$. Isto é, ao invés de se restringir ao registro de manifestações coletivas de fé e de culto - dimensão presente no documentário que acompanha a mobilização popular em torno da chegada de um penitente em Juazeiro - o filme explora também relatos e imagens de vivências individualizadas de fé como no caso de um fiel que reproduz um sermão de Padre Cícero, na imagem de um devoto orando sozinho ou no diálogo com a beata que guarda a sala de ex-votos de uma igreja em Juazeiro.

Na obra de Sarno, esse procedimento de abertura de espaço para subjetividade da fé continua em "Iaô", documentário de 1975, onde Sarno retrata o processo de iniciação do candomblé, religião que a partir do início da década de 70 é re-significada pelos cineastas brasileiros, deixando de ser vista como um mecanismo alienante para ser entendida como um instrumento de resistência cultural. Em "Viva Cariri!", um trabalho de transição entre esses dois olhares, a crítica à alienação religiosa ainda está presente, em especial no que diz respeito ao caráter institucional e político da religião. Ao mesmo tempo, essa crítica é colocada de maneira bem menos explícita e há espaço para os relatos pessoais e as manifestações de religiosidade subjetiva da população, como veremos em mais detalhe ao longo desta análise.

Ainda se apresenta uma tese a ser comprovada, mas, diferentemente de "Viramundo", onde o comentário é estruturante e carrega toda a carga crítica do autor, a tese não é entregue de antemão pelo narrador e sim construída a partir do confronto da locução e dos depoimentos. Em "Viva Cariri!", é possível ainda utilizar o conceito de "locutor auxiliar", conforme definido

\footnotetext{
${ }^{50}$ MESQUITA, 2006. Em sua dissertação, Mesquita descreve em profundidade as transformações na abordagem da religião no documentário brasileiro, do cinema novo à produção contemporânea. Ela sistematiza o uso das noções de "religião objetiva" e "religião subjetiva", apresentadas por Ismail Xavier em "Sertão Mar - Glauber Rocha e a Estética da Fome". Xavier usa os conceitos para opor duas formas de representação da experiência religiosa. Através da noção de "religião objetiva" o autor de refere à representação da exterioridade objetiva da religião, através do registro de rituais coletivos. Por "religião subjetiva", em contrapartida, se refere a representação da religião como uma vivência individual, a expressão do sentimento religioso personalizado. No caso de "Viva Cariri!" o uso da expressão "religião subjetiva" se justifica mais pelo registro de vivências individuais de fé, através do retrato de cenas de devoção pessoal, do que pelo expressão do sentimento religioso personalizado, uma vez que esse sentimento religioso ainda é observado com certo descrédito por Sarno.
} 
por Bernardet ${ }^{51}$, embora as relações entre as múltiplas vozes do documentário tenham se tornado mais complexas, como veremos de forma mais detalhada mais à frente.

A análise sociológica passa a conviver com novos elementos. O comentário, por exemplo, ganha nuances de uma ironia, que parece remeter diretamente a paródia que é pratica construtiva da canção tropicalista. A estrutura do filme se torna mais livre e há mais espaço para a experimentação formal. Se de um lado o filme incorpora formas de expressão da cultura popular tradicional - tais como o cordel, a produção artesanal e as expressões de religiosidade - de outro lado, estes sons convivem com a música tropicalista de Gilberto Gil, que abre e fecha o filme, e com um jingle de sandália de borracha, produto da industrialização da região.

Este momento de transição revela-se também no equilíbrio e na dupla natureza de diversos aspectos do filme, que podem ser traduzidos em outros binômios, além da "voz do dono"/“voz do outro" como vimos acima. "Viva Cariri!" estrutura-se numa dualidade temática. Religião e economia são os dois pólos norteadores do mapeamento que Sarno faz da região, que se aproximam ou se afastam em diferentes momentos do filme.

Em relação à abordagem, existe também uma ambigüidade clara. De um lado uma dimensão antropológica, de registro das formas de trabalho ${ }^{52}$ locais, vistas como ameaçadas pelo processo de modernização do país e pela crescente comunicação da região com os grandes centros. A produção artesanal se vê em risco provocado pela grande indústria - apesar do sonho de constituição de uma indústria local ter fracassado - e o minifúndio tem que enfrentar as intempéries naturais do sertão além de estar numa posição enfraquecida em relação aos grandes fazendeiros.

\footnotetext{
${ }^{51}$ BERNARDET, 2003

52 Em depoimento registrado em "O Nacional e O Popular na Cultura Brasileira” (Bernardet e Galvão) Sarno comenta a insistência do documentário da década de 60 no registro do fazer. Sobre a maneira como se sentia no começo da década de 70 ele diz "Tinha realizado muitos documentários sobre o que o homem do povo fazia (...) Era uma coisa que se voltava para as suas mãos (...) uma insistência muito grande na documentação do fazer (...) De um modo geral, toda esta fase do documentário brasileiro está voltada para (...) o que o povo faz com as mãos (...)”.
} 
Diversas dimensões do trabalho estão ali representadas: as pequenas oficinas artesanais, as indústrias locais, a produção agrícola e suas pequenas manufaturas. No geral, a representação do trabalho é pouco cercada de artifícios no documentário. Os planos são longos (em várias seqüências temos apenas planos seqüências) e não há nenhum tipo de informação adicional trazida pelo som - não há música, som ambiente nem narração. Nesta observação, o registro é rico em detalhes: a habilidade das mãos, os materiais reaproveitados, a pobreza dos espaços, as máquinas. Nos homens retratados vê-se tônus e vivacidade, apesar das expressões cansadas. A produção artesanal decadente, por exemplo, surge viva ao invés de resignada nessas cenas. Assim como em outros filmes da série, identifica-se aqui um olhar respeitoso para com estas formas de trabalho, que revela ainda um certo romantismo em relação à idéia de preservação da cultura popular. Ao lado da dimensão antropológica de registro, observa-se no documentário também uma dimensão política, crítica, na tentativa de entendimento da organização das diferentes forças sociais e políticas que se confrontam e se organizam na região.

Finalmente, essa dupla natureza do filme se manifesta também em termos estilísticos. "Viva Cariri!” opera em dois registros básicos: uma dimensão de reportagem cinematográfica e outra dimensão bem menos naturalista e, ao mesmo tempo, observacional e de forte caráter narrativo $^{53}$. Da mesma forma pode-se dizer que o filme oscila entre alguns momentos em que a locução (seja o comentário, seja o depoimento) é estruturante, determinando a seleção de imagens, e outros em que as imagens são estruturantes - isto é, precedem e prescindem da banda sonora. Estas seqüências em que as imagens são determinantes adquirem um caráter de autonomia em relação ao restante do documentário.

\footnotetext{
${ }^{53}$ Uso aqui a termo "narrativo" no sentido de uma seqüência temporal de acontecimentos, em que acompanhamos os desenrolar de uma ação, Na definição de Gérard Gennete, citada por Aumont em Dicionário Teórico e Crítico de Cinema, um dos sentidos de "narrativa" seria: "O enunciado narrativo que assegura a relação de um acontecimento ou de uma série de acontecimentos”. (AUMONT, MARIE. 2003. p. 208/209)
} 
O objetivo deste capítulo é a partir do levantamento das questões elencadas acima analisar de maneira mais aprofundada dois aspectos do filme: a maneira como se articulam religião e economia, seus dois pólos estruturantes, e o mapeamento das vozes que se organizam neste mosaico, mais ordenado e hierarquizado do que se poderia pensar.

\section{ESTRUTURA E TRATAMENTO DE TEMAS}

"Viva Cariri!" pode ser dividido em 36 seqüências temáticas que se agrupam em três categorias básicas: seqüências relacionadas à economia, seqüências relacionadas à religião e seqüências curtas autônomas, com forte caráter narrativo. Ficam fora deste agrupamento, as seqüências de abertura e fechamento do documentário.

O documentário expõe a decadência econômica do Vale do Cariri e traça uma relação entre a economia local e a religião, buscando demonstrar que a religião acentua a alienação política da população e, em decorrência disso, incentiva a aceitação passiva da radical desigualdade sócioeconômica da região. A produção artesanal, a agricultura familiar e o desenvolvimento industrial têm sua deterioração ligada ao abandono por parte do governo.

O documentário introduz a história de Cariri até a seqüência treze, já apontando para dois núcleos temáticos: economia e religião. Deste ponto até a seqüência trinta e dois observamos o desenvolvimento de tais temas. O bloco aborda inicialmente a economia local, trabalha em seguida os dois temas de maneira alternada, e termina se concentrando na temática religiosa.

Nas últimas quatro seqüências do filme, estes temas voltam a convergir, conforme o filme caminha para uma conclusão. Vale a pena observar que o movimento do desenvolvimento do filme em direção à religião corresponde a uma passagem para um estilo menos naturalista e mais alegórico, aumentando o caráter narrativo do documentário, isto é, a sensação de que acompanhamos o desenrolar de acontecimentos retratados como eles verdadeiramente são. 
O tema da economia de Juazeiro é explorado através de um trajeto bem esquemático. Em primeiro lugar, uma visão geral da economia do Cariri é apresentada. Somos informados de que a estrutura agrária da região é caracterizada pelo minifúndio, e passamos à história de um pequeno produtor, seguida do depoimento de um grande proprietário. O documentário aborda então o artesanato - numa seqüência em que a locução é coberta por imagens de oficinas artesanais - e finalmente, a produção industrial, através do depoimento de um representante de indústria.

Neste sentido a seleção de personagens dentro do tema pode ser considerada bastante representativa. Está retratado cada um dos setores produtivos (pequeno produtor, grande fazendeiro, artesãos, industrial), sendo a única exceção o governo, não representado na forma de entrevista. Esta ausência de personagens que representem a "oficialidade" é, contudo, coerente com a tese do documentário, já que o filme reitera muitas vezes a omissão das autoridades políticas - locais ou nacionais - em relação à resolução dos problemas sócio-econômicos da região. Esta inação se traduz na não-participação destas autoridades, na forma de personagens, no próprio filme.

Toda a trajetória econômica do Cariri é bem explicitada pela locução, através de intervenções basicamente informativas. O locutor, no entanto, não se posiciona sobre o tema, e as conclusões a que o documentário nos induz não estão colocadas na locução em off. O ponto de vista do narrador é colocado a partir da relação entre a locução e os depoimentos. Em todos os níveis, o que está sendo demonstrado é a decadência dos sistemas produtivos do Cariri, que pode ser atribuída a vários fatores: à modernização do país, à maior ligação entre essa e as demais regiões do país - mercadorias de fora passam a abastecer também o mercado local -, e à falta de iniciativa do governo, que abandonou o projeto de desenvolvimento industrial da região, bem como a produção agrícola. 
Entrecortando o eixo econômico - muitas vezes através de uma montagem alternada seqüência a seqüência - está o tema da religião, que é explorado de forma menos esquemática. A questão é abordada a partir de quatro núcleos básicos aparentemente autônomos e entre os quais não se pode estabelecer uma seqüência lógica ou causal evidente.

O primeiro núcleo é histórico, aborda a figura de Padre Cícero e se divide em duas seqüências. O segundo é o depoimento inicial do filme (que retorna ao final do documentário), em que um senhor repete um sermão de Padre Cícero. Em seguida, construído ao longo de três seqüências, temos o depoimento de uma velha beata e guardiã da sala de ex-votos. Finalmente, o quarto núcleo consiste no grupo de seis seqüências relacionadas a Cícero, um penitente que chega a Juazeiro.

A escolha dos personagens do eixo religioso não é por figuras médias, como o habitante padrão de Juazeiro, o romeiro comum ou o padre. São retratos de extremos de fé e de uma reprodução irrefletida do discurso religioso. Embora os personagens sejam tratados de maneira pouco diretiva ou interferente, tanto em relação à captação quanto à montagem - só há, por exemplo, um comentário que trata diretamente da religião ao introduzir a figura de Padre Cícero - tratase de uma seleção profundamente ideológica. Estão sendo retratados três aspectos questionáveis da religião: a alienação religiosa (através da beata), o discurso da penitência (através de Cícero, o penitente), e a reprodução do discurso religioso oficial, que é também político (através da figura de Padre Cícero e do homem do depoimento inicial).

Cláudia Mesquita observa que no filme não há qualquer hierarquização entre os diferentes momentos em que a religiosidade popular é expressa, apontando para uma religião que "resta quase como sucedâneo de uma consciência ou cultura popular". ${ }^{54}$ Embora concorde com o

\footnotetext{
${ }^{54}$ Cláudia Mesquita afirma: "Pela ausência de hierarquia entre estes diferentes momentos (...); e pela amplitude do retrato que se pretende fazer (o tema central do filme, como já mencionado, é a situação social e econômica do Vale do Cariri), a religião resta no documentário quase como sucedâneo de uma 'consciência' ou cultura popular, que se
} 
caráter de resíduo da cultura popular que a religiosidade popular assume no filme, não acredito em absoluto numa falta de hierarquização entre suas diferentes expressões. Observa-se a meu ver, ao contrário, uma organização entre os diferentes núcleos religiosos do filme de modo que alguns elementos se coloquem como estruturantes e adquiram um caráter causal dentro da argumentação proposta pelo filme.

Neste sentido, dentro do eixo religioso dois Cíceros assumem o papel de pólos organizadores, dialogando entre si. De um lado está o penitente, devoto do "padrinho", que por estar presente em diferentes momentos do documentário acaba funcionando como fio condutor do eixo religioso. Embora o personagem não seja, em nenhum momento, criticado de maneira direta pelo comentário, o filme identifica - num viés de desqualificação estabelecido pela montagem o penitente como um exemplo claro de alienação religiosa.

De outro lado, temos a figura do Padre Cícero, que é sempre tangenciada e cuja presença é metonímica e misteriosa. Em sua primeira entrada, no início do filme, o locutor nos apresenta o Padre como um "ativo líder político e autor de milagres" ${ }^{55}$. Numa seqüência posterior o comentário reforça essa idéia: “a orientação pessoal e direta de Padre Cícero, da qual é impossível destacar o coronel político do líder religioso e do maior proprietário da região, promoveu uma rápida urbanização e sobrepôs duas cidades, a mística e a econômica". A escolha de enfocar o beato, portanto, revela uma abordagem em reação à religião que traz em si esta dupla natureza: manifestação subjetiva de fé e resíduo das determinações estruturais da sociedade.

conserva, com sua lógica, ao largo do progresso que beneficia apenas as classes dominantes”. MESQUITA, 2006, página 25.

${ }_{55}$ A afirmação do caráter político de Padre Cícero não é apenas um juízo de valor relacionado a seu poder de influência do Padre em relação à população. Padre Cícero tem de fato uma dimensão de liderança política, tendo sido prefeito de Juazeiro e vice-governador do Estado do Ceará. 
Padre Cícero não é o tema do filme, mas uma presença difusa que se manifesta de variadas formas, em diferentes seqüências. Um de seus sermões, por exemplo, é reproduzido, logo no início do documentário, por um beato. Na seqüência seguinte, o locutor apresenta o Padre e o fenômeno de devoção que envolve sua figura, enquanto o texto é ilustrado por imagens de arquivo. Padre Cícero também está presente no discurso da velha beata e em cada um dos exvotos que se acumulam naquela sala. Está também no discurso do penitente. Finalmente, está na seqüência em que uma estátua gigante de Padre Cícero é retratada.

Uma seqüência de planos apresenta "dados" fragmentados sobre o Padre. Cada plano traz uma frase, um recorte de informação: dados gerais /de padre Cícero/ Nariz $70 \mathrm{~cm} /$ Orelha $80 \mathrm{~cm} /$ Boca $70 \mathrm{~cm} /$ Ombro 5,4 m. O tom aqui é fortemente irônico. Já que o filme não pode apreender de forma completa a figura do Padre, passa então aos números e aos indícios de sua presença, numa chave de deboche. Assim como não se propõe a explicar o coronelismo ou as determinações políticas da região, o documentário não busca - ou não consegue - se apropriar de modo mais abrangente do fenômeno de Padre Cícero. O que temos são pistas de uma potente influência da região. Sua presença impalpável é traduzida na reprodução de seu discurso, que ganha caráter autônomo. Suas palavras flutuam pelo Vale do Cariri, como um mistério.

Mistério que, aliás, é uma referência constante no filme. No letreiro inicial lemos numa cartela logo após o título: "Onde se revelam alguns mistérios que porventura têm no Nordeste". A frase retorna na última fala do filme, que é do fazendeiro e que marca o início da seqüência de fechamento do filme: "Sempre achei difícil ter esses ajudos (sic), esses... mistérios que têm por ventura no Nordeste". A idéia de mistério, de certa forma, distancia o documentário da pretensão de interpretar de modo conclusivo a realidade que retrata. $\mathrm{O}$ mistério não pode ser revelado, nem categorizado, ou tampouco explicado pelo olhar externo do intelectual. Existe inclusive uma certa reverência de Sarno em relação a aspectos da realidade que não podem ser definitivamente apreendidos. A religiosidade, a cultura popular e a organização política da 
região são todos mistérios que permanecem. Da mesma forma, a identificação dos mistérios não pressupõe a indicação de uma solução ou uma resolução para o enigma.

Ao lado das seqüências relacionadas aos temas da economia e da religião existe um outro grupo de seqüências, que denominei de "seqüências narrativas autônomas". Trata-se de um conjunto de cenas curtas, que apresentam situações cotidianas da vida de Juazeiro, criando mininarrativas. Em outras palavras, são cenas rápidas onde vemos o desenvolvimento de ações. Trazendo em si começo, meio e fim, essas cenas tornam-se assim independentes em relação ao resto do filme no que diz respeito à construção de significados. Ao mesmo tempo, na montagem, elas estão sempre colocadas de forma a separar duas seqüências do mesmo tema, funcionando como um corte brusco no desenvolvimento deste e como um comentário do narrador. Estas cenas têm em comum também questões de estilo, como a ausência de música, narração ou som ambiente.

Nesta categoria seriam enquadradas as seguintes seqüências: homens carregam um corpo morto por uma estrada de terra; homem reza ajoelhado em frente à grande cruz de madeira em frente à sua casa numa região rural; fotógrafo tira retrato de pessoas reunidas em volta de um caixão aberto; cruz onde estão depositados ex-votos; homem pilando; pessoas enfeitam um tumulo depois de enterrar caixão.

Numa linha paralela ao desenvolvimento da tese principal do documentário, estas "seqüências autônomas" articulam comentários sobre Cariri. Mostram enterros, velórios e pobreza, referindo-se todo o tempo à morte. Morte que, num sentido mais imediato, remete à pobreza da região e que, num plano mais generalizante, pode nos remeter ao processo de decadência da região como um todo. A morte pode ainda ser interpretada numa chave religiosa, tanto em termos concretos - do ritual que a envolve e de seu enraizamento na cultura da região - como em termos simbólicos - da promessa de uma outra realidade e da possibilidade de redenção. É justamente a promessa que se faz presente na voz do cantador - abrindo o filme e que 
retornando pouco antes do final - configurando-se como um dos eixos de narração do documentário, como veremos a seguir. Em oposição à miséria que predomina no campo visual, ele nos fala de um lugar onde todos são felizes e não precisam trabalhar.

No fechamento do documentário suas duas vertentes principais - economia e religião convergem, culminando na seqüência final em que uma velha senhora está sentada com uma cumbuca de farinha nas mãos e come, num gesto que parece completamente alheio à câmera e ao mundo que a cerca, compondo um retrato de pobreza e alienação.

\section{MULTIPLICIDADE DE VOZES}

"Viva Cariri!" caracteriza-se pela multiplicidade de vozes que dialogam e se articulam a partir de uma hierarquização velada. Entendo aqui por voz, não apenas o comentário, os depoimentos e a banda sonora de maneira geral, mas também as seqüências só de imagem que por seu caráter autônomo acabam trazendo seus próprios significados e, inseridas na montagem, atuam como comentários do narrador. Apesar da aleatoriedade que aparentemente caracteriza a forma como estas diversas vozes se organizam, existe um principio organizador responsável por essa combinação de elementos que garante uma forte coesão na construção do argumento do filme. Em outras palavras, a voz do texto se afirma no filme nitidamente, se diferenciando de todas as outras.

A idéia de montagem em mosaico, apresentada por Sarno, é desse ponto de vista completamente justificada e apropriada ao caráter de transição do documentário, onde convivem e se confrontam elementos bastante característicos de um certo documentário expositivo de caráter sociológico comum no início da década de 60 , bem como referências e posicionamentos mais próximos ao documentário do início da década de 70 . 
O locutor do dito "documentário sociológico" está presente, mas já não é o mesmo. O comentário é usado, no início do documentário, para apresentar de forma geral a situação política e econômica do Vale do Cariri, através de dados históricos. Ao introduzir a figura de Padre Cícero, percebe-se uma leve ironia, na excessiva reverência a ela, como, por exemplo, nestes trechos: "São trabalhadores rurais, lavradores e vaqueiros que aqui se concentram no dia dos mortos, para rogar sua intersecção celestial na solução de seus problemas terrenos" (...) "e crêem em seu próximo retorno a esta vida, quando, um novo Messias, dos altos da cidade santa de Juazeiro, julgará os vivos e os mortos".

Apesar da crítica poder ser intuída, ela não se explicita. Se o comentário compõe um diagnóstico em relação à economia da região, no que diz respeito à religião ele é misterioso e não fornece análises definitivas. E assim, mais uma vez, apresenta-se uma diferença no tratamento dos dois temas centrais. Em termos estruturais e estilísticos, o documentário é bem mais transparente em relação ao tema econômico do que no tratamento da religião. A religiosidade de Cariri é "mostrada" de maneira não discursiva e não interferente, em oposição a uma "demonstração" do discurso que rege o eixo econômico.

De maneira geral, observa-se que o locutor tem a função de levantar questões, mas não de sistematiza-las. Sua presença é diluída e espaçada. São ao todo seis entradas ao longo do filme, distribuídas entre os 04 e os 25 minutos. Além das entradas já citadas acima, o comentário apresenta informações sobre a cidade de Juazeiro, o artesanato e o projeto industrial fracassado da região.

Em relação às imagens, as seqüências de comentário são convencionais. Via de regra, quando existe o comentário ele é determinante: a seqüência se organiza a partir do texto enunciado, sendo ilustrada por imagens significativas para o tema. A locução sobre Padre Cícero e sobre a devoção que o envolve, por exemplo, é ilustrada por romeiros acendo velas em frente ao altar de Padre Cícero. Já o trecho que trata da estrutura agrária, traz imagens de homens cortando cana. 
Quando o comentário é sobre a decadência do artesanato, vê-se uma pequena oficina, e assim por diante.

Os últimos dez minutos do documentário não têm locução. Fica evidente então que diferentemente de outros trabalhos de Sarno, como "Viramundo", aqui não se enunciam conclusões. A diluição do comentário, por sua vez, poderia apontar para um rompimento entre o filme e os parâmetros do documentário expositivo, ou de tese, mas isto me parece exagerado. $\mathrm{Na}$ realidade o documentário produz um discurso bastante organizado sobre o Cariri e o autor ainda se acredita capaz de interpretar a realidade que filma. A mudança que de fato existe é que, em "Viva Cariri!", a articulação de sentidos já não é dada exclusiva ou prioritariamente pelo locutor, mas construída pela inter-relação de diferentes vozes, que funcionam por vezes como "locutores auxiliares". ${ }^{56}$ Como veremos em mais detalhe a seguir, por exemplo, a crítica a omissão do poder público não surge diretamente na voz do locutor, mas sim numa combinação entre as informações trazidas por ele e o depoimento do representante da indústria de mandioca. Este personagem recebe o apoio do narrador e compartilha com ele o poder de fazer uma avaliação mais generalizante da situação da indústria de região, sem ater-se somente a descrição de sua própria experiência.

Apesar de Viva Cariri não se enquadrar perfeitamente no "modelo sociológico" conforme elaborado por Bernardet, o que impede a aplicação exata da a noção de "locutor auxiliar", o uso do termo me parece justificável a medida em que ajuda a descrever a hierarquização de vozes presente no filme. Analisando detidamente as seqüências envolvidas no eixo religioso do documentário, é possível notar que a ausência do locutor, não significa que outras vozes e outros "locutores auxiliares" deixem de ser utilizados para a construção de um discurso sobre a religião ainda mais contundente do que aquele relativo à economia.

\footnotetext{
56 "De modo geral, os locutores auxiliares estão numa posição de poder, quer pelo saber, quer pelo cargo que ocupam, bem como pela função que desempenham no sistema de informação dos filmes. Estão assim mais próximos dos locutores do que dos entrevistados". (BERNARDET, 2003, p. 26)
} 
De maneira esquemática, pode-se dizer que o documentário trabalha com três tipos diferentes de enunciação - além da locução e de seqüências só de imagens - atribuindo diferentes status a cada uma destas vozes. Existem depoimentos autônomos, em que a marca é a não-interferência; depoimentos dirigidos, onde a presença de equipe é assumida; e discursos não-personalizados, que não são atribuídos nem ao locutor, nem aos personagens, mas sim a instâncias mais generalizantes como o governo, a igreja, ou mesmo o imaginário popular. Ao lado disso estão as seqüências narrativas, já citadas anteriormente.

Vale destacar ainda, que durante todo o documentário Sarno joga com o deslocamento do som e da imagem, criando significados adicionais àqueles sugeridos pelas próprias imagens. Em alguns momentos este deslocamento gera dúvidas sobre o enunciador, em outros momentos o que está sendo dito é reforçado ou enfraquecido graças ao deslocamento. De uma forma ou de outra, a voz do texto se expressa através destes procedimentos, de uma maneira mais sutil e menos transparente do que através do comentário. Um exemplo disso é a entrevista do fazendeiro, analisada detidamente mais adiante, em que Sarno tira a sincronia entre som e imagem. Enquanto em seu discurso em off o fazendeiro coloca-se na posição de força progressista que luta pelo desenvolvimento da região, as imagens o mostram sacando uma arma e atirando para cima, revelando a força e a violência do coronelismo e desmentindo o personagem.

Para traçar contornos mais nítidos entre os diferentes tipos de enunciação presentes no documentário e caracterizar melhor cada uma destas vozes, faz-se necessária uma análise em filigrana de algumas seqüências do documentário, que sintetizam estes procedimentos narrativos. 


\section{DISCURSOS AUTÔNOMOS}

Há três depoimentos em “Viva Cariri!" nos quais não aparecem as perguntas do diretor, nem é notada a presença da equipe. De modos diferentes, cada uma destas entrevistas funciona no sentido de endossar a linha de raciocínio desenvolvida pelo autor através da montagem.

Uma delas é a terceira seqüência, em que surge o primeiro depoimento do documentário. Neste, um senhor de meia-idade repete um sermão de Padre Cícero, estabelecendo uma passagem entre a abertura do documentário - com imagens aéreas do Vale do Cariri e imagens gerais de Juazeiro - e a seqüência seguinte, em que o locutor irá introduzir a figura do Padre. O ponto que se destaca aqui é a maneira como o tratamento pouco interferente da narração em relação ao entrevistado gera dúvidas em relação à origem do discurso e, por isso mesmo, gera também significado.

O tal senhor está sentado em frente a uma casa simples. Ele não olha nem para a câmera, nem para o entrevistador; o enquadramento é centralizado e não há música. Ele introduz rapidamente o sermão ${ }^{57}$ - que deduzimos ser de Padre Cícero quando, na seqüência imediatamente seguinte, a montagem introduz a figura do beato - que vai enunciar, descrevendo a situação em que o Padre proferia aquelas palavras. Alguns segundos se passam antes que possamos perceber que ele é um reprodutor deste discurso e não seu autor, uma vez que em nenhum momento a origem desta fala é indicada pelo narrador. O sermão defende uma postura de entrega total à religião, terminando na seguinte frase: "tudo isto vos entregamos pelo amor de Nosso Senhor Jesus Cristo, a quem juramos esta mesma entrega, que é total, sem reservas, ainda que para nós custe a morte...”. A ausência de indicação de origem e a não-intervenção do entrevistador - por quase dois minutos não há interlocução aparente entre o diretor e o

\footnotetext{
${ }^{57}$ Esta seqüência poderia ser considerada um exemplo do que no início do capítulo classificamos de "religião subjetiva”, uma vez que apresenta o registro - embora sem abrir espaço para uma expressão livre do sentimento de fé - de uma vivência individual, que relembra o ritual coletivo (o momento do sermão) através de um filtro pessoal.
} 
depoente - criam uma sensação de discurso autônomo. Isto é, de uma fala supostamente livre do controle do diretor, mesmo estando caracterizada uma situação de entrevista.

Ao mesmo tempo, a idéia de que Padre Cícero ainda se faz presente, na memória do povo que reproduz suas palavras, é absolutamente central para o documentário e está estreitamente ligada à aparente "autonomia" deste discurso. As palavras de Padre Cícero simplesmente ecoam, permanecendo diluídas na atmosfera de Cariri, sem que seja necessária sua presença. Explicitase então, logo de saída, o mistério que vai ser trabalhado ao longo de todo o filme.

Esse mesmo efeito volta a ser criado mais adiante - desta vez num contexto econômico e não religioso - na vigésima quarta seqüência do documentário. Trata-se do depoimento de um representante da Cimasa, uma indústria de processamento de mandioca em plena crise. Há mais uma vez uma propositada falta de clareza a respeito da identidade do enunciador. Nesta seqüência, a dúvida liga-se a uma identificação entre o discurso do entrevistado e a visão defendida pelo narrador, através da montagem, sobre as causas do fracasso industrial da região.

A seqüência tem início com imagens da fachada da Cimasa, indústria desativada, sobre a qual entra uma voz em off. Pelo timbre e pela maneira formal de falar desta voz, a primeira impressão é de que se trata do locutor do documentário. Esta impressão se mantém até que o personagem que fala entra em quadro. Percebemos então que o depoente é um representante da Cimasa filmado num plano americano bem centralizado - que olha para a câmera e fala sobre o surgimento da fábrica.

Segundo seu depoimento, a indústria foi resultado do projeto Boris Assimov (projeto de desenvolvimento industrial para a região do Cariri sobre o qual o espectador já foi informado em uma seqüência anterior). Tendo recebido a aprovação da Sudene e recursos do Banco do Brasil, a Cimasa nasceu com a finalidade de solucionar os problemas agrícolas da região. Entretanto, afirma o entrevistado, com a crise na comercialização da mandioca - causada por 
um decreto extinguiu a obrigatoriedade de $10 \%$ de mistura da raspa da mandioca ao trigo - a empresa se viu obrigada a fechar as portas e aguardar novas medidas das "autoridades responsáveis". Enquanto o empresário fala sobre a crise da indústria, a câmera faz um movimento circular partindo dele e descrevendo o ambiente em que ele está. São mostrados caminhões parados e o depósito vazio, até que a câmera retorna ao empresário ao final de sua fala.

Durante toda a seqüência, de pouco mais de dois minutos, o empresário discursa sem pausas e sem interferências, responsabilizando as "autoridades competentes" pelo fracasso do projeto industrial da região. Desta forma, atua como um "locutor auxiliar" na construção de uma visão crítica endossada fortemente pela montagem. Tanto em termos de conteúdo como em termos de estilo, o depoimento do representante poderia ser atribuído ao locutor principal, que empresta, por alguns segundos, sua autoridade a este discurso e permite que se crie uma confusão sobre sua origem. A fala do empresário não é questionada, nem enfraquecida, por nenhum tipo de corte ou interferência e se dirige quase que diretamente ao espectador. Ao mesmo tempo, o fracasso ao qual o empresário se refere está claramente demonstrado visualmente: ele está de pé em meio a um lugar enorme e sem vida, onde a morte do projeto de desenvolvimento local é nítida.

Um pouco diferente é o tratamento dado ao fazendeiro, presente em três seqüências: a dez, a doze e a trinta e três - sendo as duas primeiras separadas por apenas um plano de dez segundos em que vemos ex-votos depositados na base de uma cruz. O fazendeiro representa diversos aspectos centrais da organização político-econômica da região e personifica o coronelismo. Apesar disso, o documentário desenvolve uma relação ambígua com o personagem. Se por um lado sua imagem está associada a abominável oligarquia rural, que domina e manipula de forma violenta a população rural, por outro ele se aproxima do ponto de vista do narrador quando defende o desenvolvimento econômico local - do qual ele seria motor - e critica o abandono governamental. É ele, por exemplo, que recebe do narrador o privilégio de fechar o 
documentário. Na última fala do filme, este fazendeiro retoma a frase da cartela de abertura, e fala sobre "os mistérios que porventura tem no nordeste".

O aparente apoio da narração ao personagem é mais nítido em sua primeira entrada, na qual o fazendeiro busca demonstrar seu poderio econômico, apesar da falta de estímulo do governo ao desenvolvimento local. Um plano próximo e bem centralizado apresenta o fazendeiro sentado, com uma mesa à sua frente, olhando para o entrevistador, que está à esquerda da câmera. Apesar da mise-en-scène sugerir que o entrevistador está presente, sua pergunta é omitida pela montagem e o fazendeiro fala longamente e sem interrupções sobre as dimensões e os recursos de sua fazenda. Num tom bastante formal, ele enumera suas posses: 40 mil covas de banana, 350 tarefas de sisal e assim por diante. Embora os números impressionem, seu depoimento conclui que as máquinas que possui para processar esta matéria-prima - 16 para o barbante e 09 para beneficiar e polir - são insuficientes: “(...) eu só podia continuar com este trabalho com umas 40 máquinas ou 50 máquinas a mais. Mas se não há auxílio do governo eu vou rodando com as minhas mesmo e ele que seja bem-vindo, que seja bem aparecido, que seja bom governo". De uma maneira enviesada, a fala do fazendeiro aponta para o abandono do governo, que seria "bem-vindo" caso resolvesse ajudar e estimular o crescimento da região.

Neste caso, a não-interferência não implica um questionamento de origem do enunciador, mas apresenta um padrão de ambigüidade que se repete no filme e que, aqui, diz respeito ao endosso do ponto de vista do fazendeiro pelo narrador. Um eventual espectador intelectualizado de esquerda - que presumo ser o público ao qual o filme se dirige - não se identificaria de imediato com a figura do fazendeiro e nem traçaria uma correspondência óbvia entre seu discurso e o ponto de vista do autor. Apesar disso, o fazendeiro efetivamente corrobora a linha de raciocínio conduzida através da montagem, que parece bastante crítica a falta de iniciativa e a ineficiência do governo em relação à crise econômica da região. 
A identificação entre narrador e fazendeiro é, entretanto, frágil e se dissolve na segunda aparição da personagem, na qual há uma outra mise-en-scène e uma nova relação entre filme e entrevistado. Se a cena anterior poderia estimular uma certa simpatia em relação ao drama do fazendeiro, o que se vê em seguida é a revelação da dimensão autoritária e reacionária da mesma figura. Através do deslocamento de som e imagem, Sarno desmente a fala do entrevistado. Assim a seqüência adquire um sentido radicalmente diferente do anterior, eliminando qualquer possibilidade de solidariedade em relação ao personagem.

O fazendeiro está à esquerda do quadro, num plano que revela uma garrafa de pinga na mesa à sua frente e o microfone. A situação parece mais descontraída do que a do primeiro depoimento, sugerindo que o que vemos é uma conversa entre equipe e entrevistado após a filmagem. No plano imagético o fazendeiro continua falando e olhando para o entrevistador, mas o som direto está em BG. O que se ouve é um outro trecho de seu depoimento, sobreposto à imagem, no qual, num tom político e exaltado, ele discorre sobre os sacrifícios que precisou fazer - abrir mão da casa, do armazém, do gado e de outras fazendas - para manter a Fazenda Coipé. Ele diz: "trabalhando com boa vontade, pelo Nordeste, pelo Brasil, pela minha boa vontade, pela qualidade de nordestino verdadeiro típico cearense forte...". Neste ponto do discurso, o fazendeiro olha para o lado direito e dá três tiros - que ouvimos, num sobe-som rápido - para o alto. Não fica claro em que momento da conversa entre equipe e fazendeiro que vemos, mas não ouvimos - os três tiros acontecem, mas esta a descontextualização é proposital.

A utilização de duas pistas diferentes de áudio, complementadas no final pela entrada da música da próxima seqüência, reforça a multiplicidade de vozes. Por um lado, temos o discurso político, de fomentador do desenvolvimento nordestino. Mas por outro lado, o coronel é desmascarado. Ele não é um desenvolvimentista, mas sim um reacionário, que representa o que há de mais detestável e permanente na cultura agrária nordestina. Se sua fala serve à construção de um 
olhar crítico em relação ao governo, as imagens revelam seu autoritarismo e, ao serem utilizadas sem áudio e por isso mesmo fora se seu contexto, acentuam o absurdo da situação.

Dessa forma, a entrevista do fazendeiro - assim como os dois outros depoimentos explorados acima - funciona como ferramenta para o estabelecimento de um ponto de vista externo a ele, pertencente ao autor. Embora o locutor não se faça presente de maneira literal, a voz do texto se coloca de forma nítida em relação a estes depoentes - ora endossando, ora desqualificando para construir argumentos centrais para o desenvolvimento do filme: a presença impalpável de Padre Cícero confirmando o poder alienante da religião; a omissão governamental como fator chave para a falência do projeto de desenvolvimento local; e a sobrevivência do coronelismo que representa um dos modos básicos de dominação e de perpetuação das desigualdades da região.

\section{DISCURSOS DIRIGIDOS}

Ao lado destes três depoimentos, classificados como discursos autônomos, o documentário conta com outros dois entrevistados que recebem um tratamento diferente daquele descrito até agora. São eles: o produtor de mandioca e a beata guardiã da sala de milagres. Nestas entrevistas, o discurso se constrói a partir da interação assumida entre equipe e personagem.

Por um lado este procedimento aproxima o documentário de trabalhos que começavam a ser feitos na década de 70 e buscavam quebrar o distanciamento da voz em off onisciente e autoritária, substituindo o papel de "objeto" do entrevistado popular pelo de "sujeito" capaz de refletir sobre sua própria experiência. Apesar disso, na prática, em "Viva Cariri!", a interação assumida funciona como mais uma ferramenta de reforço à tese construída pelo autor, que assume sua presença, mas usa o papel de condutor para comprovar seu argumento. A "voz do outro", ainda que presente, termina atuando como um mecanismo para a construção do discurso do realizador. 
A sétima seqüência pode ser tomada como exemplo. Inicia-se com um plano fechado de um pequeno produtor de mandioca que está de pé, em frente à sua oficina de produção de farinha, e olha para esquerda, na direção de um suposto entrevistador. Ele não está em quadro, mas sua pergunta parece ter sido gravada com som direto. Ao fundo, acontece a produção de farinha de mandioca e várias pessoas trabalham. O entrevistador pergunta quanto tempo demora o plantio da mandioca. O produtor responde que são dois anos, mas que se houver doença metade da plantação pode se perder, como aconteceu no último ano. O entrevistador insiste: "E que resultado o senhor teve?". O produtor explica que não conseguiu ganhar nada. Seu depoimento vai para off, vê-se planos de cobertura de homens girando manivela, homens e mulheres trabalhando na produção da mandioca. A banda sonora começa a ser invadida então pelo áudio da próxima seqüência: “meu padrinho Cícero, lá em seu trono de glória...”.

É interessante notar como o entrevistador conduz de maneira clara a seqüência, usando as perguntas para construir um significado a partir da fala do pequeno produtor, que - pelo menos do ponto de vista do diretor - não seria auto-explicativa. A primeira pergunta, aparentemente ingênua e técnica, oferece ao produtor a oportunidade de se queixar das dificuldades do último ano. A segunda pergunta é de certa forma redundante, uma vez que insiste para que o produtor fale sobre os resultados do último plantio, o que já havia sido respondido. Assim reforça-se a função deste personagem - o primeiro exemplo concreto dentro do tema da economia do Cariri - na comprovação do argumento de que a economia da região encontra-se em franca decadência.

Em termos da montagem, esta seqüência se situa após a apresentação inicial da economia do Vale pelo locutor, na seqüência cinco. Sobre imagens do plantio de cana-de-açúcar, a locução em off nos explicara que o Vale do Cariri, localizado entre cinco diferentes estados, atraiu romeiros e migrantes acossados pela seca e tem suas baixadas férteis disputadas por minifúndios de agriculturas primitivas. Logo após esse panorama inicial surge a entrevista do pequeno produtor de mandioca, funcionando à primeira vista como exemplo do minifúndio no Vale e 
das dificuldades enfrentadas pelo agricultor local. Entretanto, o agricultor, além de ilustrar o que a locução da seqüência anterior sugerira, tem também uma função de ligação, ao apresentar uma informação nova e complementar à locução, que será desenvolvida duas seqüências à frente, na entrevista com o fazendeiro. A idéia central de sua fala é a de que, apesar das terras férteis do Vale, o plantio de mandioca por pequenos proprietários enfrenta muitas dificuldades e que, em suas próprias palavras, "ninguém pode ganhar". Mais à frente o fazendeiro, irá retomar a idéia de que "ninguém pode ganhar", acrescentando a ela uma explicação: nem o pequeno produtor nem o grande proprietário podem, sem a intervenção do poder público, solucionar os problemas econômicos da região e, sem que a situação mude, todos vão fracassar.

Ainda do ponto de vista do estabelecimento de relações a partir da entrevista do pequeno produtor pela montagem, vale notar que, entre a introdução do tema econômico pelo locutor e o depoimento do agricultor, há uma seqüência muito curta - sem som ambiente, música ou locução - em que homens carregam um corpo enrolado em lençol branco, acompanhados por outros homens e mulheres, numa estrada de terra. Esta inserção, incluída no grupo que denominei de "seqüências narrativas autônomas", apesar de sua total independência formal e discursiva em relação à cena do produtor não deixa de funcionar também como um comentário do narrador. Trata-se de um corpo morto, contrastando às baixadas férteis mencionadas pelo locutor na seqüência anterior, cercado por trabalhadores, que em nada diferem - ao menos aparentemente - do pequeno produtor.

Da mesma maneira, a seqüência seguinte - anunciada ao final da entrevista do produtor pela entrada de um canto religioso, que nada mais é do que uma prece a Padre Cícero - reforça a dimensão de desesperança da entrevista. Trata-se de um plano curto de um senhor de idade, ajoelhado em frente a uma cruz, rezando de olhos fechados e - pelo que a música nos induz a pensar - pedindo a ajuda do padre milagreiro. ${ }^{58}$ "É Padre Cícero mesmo a única esperança do

\footnotetext{
${ }^{58}$ Essa seqüência é apontada por Cláudia Mesquita como um dos indícios da insipiente presença da "religião subjetiva" no documentário, por ter um caráter íntimo e subjetivo, do ponto de visão retratar esta experiência solitária do fiel. Concordo com essa percepção, embora, como colocado, dentro da montagem, a cena funcione
} 
Cariri?", nos parece perguntar o narrador. Colocando a oração como resposta às agruras do agricultor, mais uma vez, o filme reforça a dimensão paralisante da religião que, apesar de gerar conforto, estimula o conformismo ao sublimar a insatisfação e o desejo de mudança.

O caráter alienante da religião, que na seqüência que sucede a entrevista do agricultor é periférica, surge de maneira mais explícita na única entrevista propriamente dita do eixo religioso do documentário, com a velha beata que é guardiã de uma sala de ex-votos em Juazeiro. Neste depoimento, que se divide em três entradas relativamente longas (seqüências 15, 17 e 19, com respectivamente 02'25”, 02'25” e 01'27”), a interação entre realizador e entrevistado também acontece, embora as cenas caminhem em direção a uma abordagem mais e mais observacional. O espaço e o tratamento dados a esta senhora são absolutamente fundamentais para a articulação do documentário e levantam diversas questões de estilo decisivas para o filme.

Em sua primeira aparição esta senhora está, vestida de preto, em uma sala de ex-votos e, em perspectiva, a câmera revela que o espaço está atulhado de objetos. A câmera se movimente para esquerda e vê-se uma segunda senhora vestida de branco saindo de uma porta no fundo desta sala e andando lentamente em direção à câmera. Em primeiro plano, a beata vestida de preto fala sobre Padre Cícero e os conselhos que ele dava: "Seja bom para seu pai e sua mãe”. O entrevistador pergunta o que mais ele dizia, mas não é possível entender a resposta. "Vê aqui tudo", ela diz apontando para as diversas peças - retratos, bonecas, esculturas - da sala. “Tirou?", ela pergunta ao realizador, se relacionando com a câmera como se esta fosse uma máquina fotográfica. “Tudo isto é o que?”, pergunta o entrevistador. Ela responde apontando, mas novamente é difícil entender sua fala. Ela anda para a esquerda - a câmera acompanha - e começa a pegar ex-votos, explicando porque cada um está lá. Neste momento, a segunda senhora já está próxima, entra em quadro, e observa a situação num certo estado de ausência.

como comentário bastante crítico da religião, apontando para as implicações políticas da fé religiosa. A mesma ambigüidade, está presente na entrevista da beata. Embora o documentário explore uma experiência individual de fé, na construção do argumento do filme, o sentido da seqüência se constrói à total revelia da subjetividade do personagem. 
O entrevistador prossegue fazendo perguntas, que são claramente ouvidas: "Por que trouxeram essa?"; "Como curou esta chaga?". Diante desta última pergunta a beata fica extremamente brava, quer saber se o entrevistador não está vendo que foi Padre Cícero quem curou a chaga, e diz que não vai mais contar nada. A outra senhora se aproxima e intervem pedindo, que tenha paciência com os novatos, com "os que não sabem". A beata continua resmungando, nervosa.

No artigo em que define o conceito de "dramaturgia natural" ${ }^{59}$ Sérgio Santeiro aponta justamente esta seqüência de entrevista com a beata como exemplo do que ele chama de "crise da representação". Para Santeiro, com o som direto, o documentário adota também a encenação do drama ficcional. Mas, na encenação documentária, ao invés de representar uma personagem fictícia, o depoente lança mão de recursos expressivos para representar o seu próprio papel, funcionando assim como "ator natural".

$\mathrm{Na}$ realidade, segundo Santeiro, o entrevistado encarna uma tripla personalidade: ele é o sujeito real, determinado socialmente e que fala de uma posição social concreta; ele é o personagem dramático que idealiza o sujeito real, selecionando suas características a partir de seus valores reais; e ele é o ator natural, que atualiza o personagem dramático criado por ele mesmo em um novo confronto com a realidade, no qual a espontaneidade dá lugar a encenação. Em outras palavras, o sujeito real seria aquele que pode ser definido, de um ponto de vista externo, por um

\footnotetext{
59 No artigo "Conceito de Dramaturgia Natural”, publicado em 1978, na revista Filme Cultura, Sérgio Santeiro define o conceito de dramaturgia natural e defende a idéia de que as imagens sonoras teriam o potencial de revelar coisas não necessariamente previstas ou percebidas pelo cineasta. Isto porque, para Santeiro, apesar das imagens sonoras também estarem submetidas à instância ordenadora da montagem, controlada pelo cineasta, no seu momento de gravação elas são anti-seletivas, isso é, o próprio depoente define uma postura que marca sua relação com a cena. As expressões faciais, a relação com o local, o contraponto entre entrevistador e entrevistados são todos elementos dotados de significado e que compõe um quadro de organização do registro, que, do ponto de vista de Santeiro, antecede e sobrevive às escolhas do cineasta, permanecendo visível mesmo dentro do fluxo da montagem. Este conjunto de recursos expressivos seria utilizado pelo depoente para representar seu próprio papel. Assim, este modo de organização da cena - a maneira de enunciar, as entonações, a comportamento cênico, etc - é definido por Santeiro como dramaturgia natural. Ainda que a percepção do caráter de atuação que se impõe na situação da entrevista seja acurada, Santeiro talvez seja muito otimista no que diz respeito à crença numa autonomia do depoente para definir um modo de organização de sua atuação, capaz de sobreviver às escolhas do cineasta.
} 
posicionamento social concreto, ou seja, pelo lugar que ocupa objetivamente na estrutura social. Já o personagem dramático é criado pela subjetividade do próprio entrevistado. Trata-se da maneira como, idealmente, o sujeito real gostaria de ser reconhecido e reúne aspectos e características que o sujeito real considera preferenciais. Esse personagem ideal, entretanto, apesar de perfeito e coeso na imaginação do sujeito real, precisa ser colocado em prática, concretizado, através da performance do sujeito e de seu confronto com o entrevistador. Ao tentar atuar o personagem que idealizou, o sujeito real assume o papel de ator natural. Dessa forma, a fiel representação do personagem dramático depende do bom desempenho do ator natural. Assim como na ficção, muitas vezes, o mau desempenho do ator acarreta no fracasso da encenação, na dramaturgia natural os riscos são os mesmos. O que Santeiro chama de "crise da representação" são justamente os momentos em que o despreparo cênico do ator natural ou a interferência da realidade na cena colocam em risco toda a encenação. ${ }^{60}$

Santeiro defende a idéia de que a beata, quando mostra ao entrevistador peças da sala de milagres e explica seus significados, não está trabalhando dentro da relação entrevistada/entrevistador. Do seu ponto de vista, a relação que se estabelece é a de sacerdote/fiel. Ela representa a voz da tradição e não pode ser contestada. Ao pedir que ela explique o significados das peças e possivelmente repita o que já disse - ou porque ela já dissera

\footnotetext{
${ }^{60}$ Ismail Xavier, em seu artigo "Indagações em torno de Eduardo Coutinho" (XAVIER, 2003) também se debruça sobre a questão da performance do depoente, analisada a partir da obra de Eduardo Coutinho. Xavier aponta para direções próximas de Santeiro, como o desejo do entrevistado compor a melhor representação possível de si próprio, já que tudo que revela vem de sua ação diante da câmera, e o desejo do entrevistado de se apropriar da cena, compondo um estilo e um modo de se comunicar. Levanta também outras questões de interesse, dentro da esfera do personagem no documentário: a tendência do entrevistado de compor sua fala segundo o que julga ser a opinião dos interlocutores (o cineasta e a câmera, representando a opinião pública); o poder catalisador da câmera como possível compensação da assimetria de poderes entre entrevistado e entrevistador; a dualidade entre espontaneidade e teatro, fazer-se imagem e ser verdadeiro, presente na situação de entrevista; o desejo do entrevistado de ser personagem clássico que se revela, por exemplo, no respeito à regra teatral clássica da quarta parede. Ainda que seja claro em afirmar a assimetria de poderes entre o entrevistador e o entrevistado, Xavier se aproxima da idéia de que a cena pode revelar algo inesperado, como sugerido por Santeiro, e que esta revelação sobrevive à montagem. Ao comentar o documentário baseado na entrevista, nos moldes de Coutinho, ele afirma: "Neste caso, a composição da cena e sua duração buscam potencializar a força do instante; produzir, no encontro, a irrupção de uma experiência não domesticada pelo discurso, algo que, apesar da montagem e seus fluxos de sentido, retém um quê de irredutível na atuação do sujeito, mais ou menos revelador, sempre conforme uma combinação peculiar de método e acidente permita". (XAVIER, 2003, p.227).
} 
antes dele começar a gravar ou para garantir que o som seja registrado - o realizador faz com que uma necessidade técnica e profana interfira num universo supostamente sagrado, o que deixa a beata profundamente irritada, por talvez suspeitar que o pedido de repetição encubra a incredulidade do entrevistador. Na situação sacerdote/fiel o primeiro oferece a revelação e o segundo a recebe, sem interrupções e, conseqüentemente, sem contestações.

Ainda dentro da leitura proposta por Santeiro, é por sua insegurança como protagonista que a beata se irrita e para de falar gerando uma ruptura na comunicação. A situação de entrevista é retomada quando a beata é socorrida pela segunda senhora que diz que ela precisa continuar, para explicar aos "que não sabem". A coadjuvante afasta dessa forma o fantasma da contestação, afirmando que a repetição não é causada pela impertinência dos que sabem demais e sim pela ignorância dos que sabem de menos, assumindo o papel principal. A beata protagonista, em contrapartida, ao estragar a cena põe em dúvida a própria encenação, uma vez que admite a hipótese de contestação. Assim, é registrado, nos termos de Santeiro, "o aleatório significativo" de um momento privilegiado em que a crise da representação emerge, superando a representação consciente.

A interpretação de Santeiro é precisa no que diz respeito à estrutura interna da seqüência. Mas cabe investigar com maior profundidade porque a crise é desejada pelo autor, já que ele a preserva integralmente na montagem. Enquanto a fala do entrevistador é muito clara, o discurso da velha senhora é, na maior parte do tempo, caótico e incompreensível. De nenhuma maneira o narrador tenta maquiar esta confusão, editando o discurso. Ao contrário, a seqüência não tem qualquer corte, causando uma sensação de desconforto em relação à protagonista. De certa maneira, o tropeço da protagonista desmonta a relação sacerdote/fiel, que não é endossada pelo realizador, e revela a dimensão contestável e falível da fé religiosa.

Neste sentido, em relação à montagem, a beata funciona como um "não-locutor auxiliar". Isto é, apesar de não articular um discurso, a fala desorganizada desta senhora ajuda a construir uma 
visão crítica da mitificação de Padre Cícero. A desarticulação funciona então como articulação de um discurso sobre alienação.

Na segunda entrada da beata, o momento de ruptura já foi superado e está recolocada a situação em que a beata se relaciona com o entrevistador, mostrando a ele uma série de objetos e explicando o significado de cada um deles. Ela não olha para a câmera e parece fazer isso não por respeitar a quarta parede teatral, mas sim por simplesmente desconsiderar a câmera como elemento que faz parte da cena; o que corrobora a visão de Santeiro de que ela não atuaria na relação entrevistador/entrevistado. Há um certo automatismo em suas ações repetitivas e notase o descolamento dela em relação ao mundo que a cerca, sensação que se torna ainda mais nítida em sua terceira e última entrada.

A seqüência começa num plano da segunda senhora, que olha para a câmera com uma expressão de completa ausência. Ouve-se alta a voz da protagonista, fora de quadro. A câmera se movimenta até ela que está na porta da sala de milagres, falando para a rua. Sua fala tem caráter religioso, mas é difícil de entender; a sensação produzida é a de que fala para o nada. Vira-se para dentro da sala e começa a andar. Passa por alguém da equipe e continua falando. "Deus te acompanhe, Deus te acompanhe". A princípio não se sabe se ela está falando para a equipe ou para alguém na rua, mas, eventualmente, percebe-se que seu discurso não é dirigido a alguém específico. Passa pela segunda senhora, que continua imóvel; anda até o fundo da sala, de costas para a câmera, falando sozinha. A segunda beata a segue e a câmera parada acompanha as duas senhoras indo embora.

A progressiva sensação de descolamento da realidade, que se construiu desde sua primeira aparição, completa-se nesta seqüência. O entrevistador e a equipe parecem ter desistido da interação com a beata e a câmera é absolutamente não interferente, criando-se assim uma situação narrativa, onde passamos a acompanhar o desenrolar de uma ação. A encenação está arruinada, mas o registro é significativo. Trata-se do retrato de uma espécie de transe, e - sem 
que nenhuma palavra seja dita pelo locutor principal - cria-se uma associação imediata entre o descolamento da realidade e a fé religiosa.

De formas bastante distintas, as duas entrevistas onde a presença do entrevistador é assumida são importantes para a consolidação de questões básicas para o filme. O produtor de mandioca, além ser a personificação do que seria o pequeno agricultor médio do Vale do Cariri, faz a transição entre a constatação de que a economia do Vale passa por dificuldades e a sugestão de que o poder público é culpado por isso. Além disso, dentro da montagem, a entrevista do produtor se localiza entre dois comentários visuais do narrador que sugerem que a resposta para esta crise não está na religião.

No caso da beata, não apenas seu depoimento é fundamental dentro do discurso altamente crítico desenvolvido pelo filme em relação à religião e ao mito de Padre Cícero, como também é importante dentro da dualidade estilística do documentário. A gradual desistência do entrevistador em interagir com a beata, optando, a cada uma das entradas, mais e mais por uma postura observacional, define uma das chaves de estilo do filme. O documentário opera entre um distanciamento do observador que, como acontece gradualmente na entrevista da beata, cria um efeito narrativo ao mesmo tempo em que paradoxalmente afasta as imagens de um registro naturalista; e uma abordagem mais no estilo de reportagem cinematográfica.

Finalmente, como tem sido observado em relação ao modo de funcionamento dos diferentes tipos de enunciação do documentário, nestas entrevistas dirigidas o narrador se afirma fortemente, assumindo inteiramente o papel de organizador e modulador do material fílmico através da voz do entrevistador; dos comentários que surgem através da montagem; e até mesmo do estabelecimento contínuo de relações entre estas vozes e as diversas outras que se manifestam no filme. 


\section{DISCURSOS NÃO-PERSONALIZADOS}

Nas entrevistas analisadas até este ponto, independentemente do nível de interação assumido frente às câmeras entre entrevistador e entrevistado, as presenças da equipe e da câmera são elementos determinantes da mise-en-scène. O entrevistado fala com o realizador ou responde a estímulos propostos por ele - ainda que, no caso da beata, a relação que se estabelece entre entrevistada e entrevistador seja de outra ordem, como já vimos. Mesmo no caso do senhor que reproduz o sermão de Padre Cícero, no qual as perguntas não são escutadas e a sensação é de autonomia, percebemos que ele fala para a câmera e porque a câmera está presente. Ou seja, a equipe é a motivação do discurso.

Observaremos agora um outro grupo de seqüências em que a postura não interferente da equipe é radicalizada e o realizador assume uma posição bem mais observacional e fora da cena. Não pretendo de qualquer forma defender a crença na objetividade do registro observacional, e nem afirmar que a câmera que filma, estando fora da cena, tenha menos influência na ação dos personagens observados. O que interessa, neste momento, é refletir sobre como a postura observacional da câmera aumenta o caráter narrativo destas seqüências, permitindo que se acompanhe o desenrolar de ações que acontecem aparentemente de modo espontâneo. São cenas em que os fatos parecem não se reportar a um "enunciador real" ${ }^{61}$, possibilitando uma leitura ficcionalizante por parte do espectador.

\footnotetext{
${ }^{61}$ Retomo o termo "ficcionalizante" criado por Roger Odin, um neologismo que adoto com o apoio da tradução de Eric Roland René Heneault do artigo "A questão do público: uma abordagem semiopragmática” do autor, publicado na coletânea Teoria Contemporânea de Cinema, volume II, pela Editora Senac em 2005. Justificado o uso do termo do ponto de vista da correção da redação, passemos ao conceito em questão. Odin, de maneira muito interessante, distende as fronteiras entre documentário e ficção ao propor a existência de diferentes modos de leitura e de significação - entre eles o documentarizante e o ficcionalizante - que se estabelecem, de maneira dinâmica, na relação entre filme e espectador. Cada um desses modos se caracteriza de um lado por diferentes posturas do espectador e de outro por uma série de indicações fornecidas pelo filme do modo que desejaria ver utilizado para sua leitura. Uma das que questões centrais para a caracterização dos diferentes modos é a maneira como a figura do enunciador é construída, como colocado por Odin: "Parece-nos, com efeito, que o que constitui a leitura ficcionalizante não é tanto a construção de um 'eu-origem fictivo' mas, mais radicalmente, a recusa pelo leitor de construir um 'eu-origem"'. (ODIN, 1984, p. 263-277.). Num outro texto, ele retoma a questão: "Se o modo documentarizante pede a construção de um enunciador real, mas deixa quase livre a escolha dos outros processos (podemos construir ou não um mundo, construir ou não uma narrativa, produzir ou não um efeito de colocação em fases, etc), ao contrário, o modo ficcionalizante responde a uma organização fixa, muito estrita, que coloca no
} 
Estas situações apresentam vozes não-personalizadas. Elas não fazem parte do comentário, não pertencem aos próprios personagens e nem reproduzem o ponto de vista do narrador. São discursos que se identificam com instâncias mais gerais como o governo, a igreja e o imaginário da população do Cariri. Dessa forma, fazem parte deste terceiro núcleo as seqüências do cantador, do penitente e das autoridades competentes.

Logo após os créditos iniciais (duas cartelas - "Viva Cariri!" e "onde se revelam alguns mistérios que porventura têm no Nordeste" - seguidas pelos créditos da equipe), na abertura do documentário, surge a voz do cantador. Sobre imagens aéreas do Vale do Cariri - vales, árvores, áreas cultivadas - começamos a ouvir "Viagem a São Saruê", um poema de cordel musicado, que descreve um lugar idílico, onde a prosperidade impera. Ele canta: "Doutor, mestre pensamento/ me disse um dia: você/ Camilo vá visitar/ o Pais São Saruê/ é o melhor do lugar/ que nesse mundo se vê...”

Num primeiro momento, sobre as imagens aéreas, a música parece corresponder a uma descrição adequada do que vemos. Mas conforme nos aproximamos da cidade de Juazeiro e, em seguida, dos trabalhadores rurais amontoados num caminhão, cria-se uma sensação de estranhamento. Na voz do cantador, o sonho continua: "mais adiante uma cidade/ como nunca não vi igual/ toda coberta de ouro/ e forrada de cristal/ lá não existe pobre/ é tudo rico afinal...”. Neste ponto as imagens de Juazeiro e da população funcionam como contra-exemplo do que a banda sonora sugere. "Não", pensa o espectador, "não é deste lugar que esta música está falando".

A escolha de abrir o filme com um poema de cordel - que de forma fantasiosa aponta para uma redenção possível - sugere também uma pergunta: qual o status atribuído à cultura popular por

comando dois processos dos quais tudo provem: a narração (...) e um processo enunciativo: a fictivização (construir uma ficção supõe, em primeiro lugar, que o narrador seja instituído como enunciador fictício)”. ODIN, 2005 , p.34. 
Sarno? Ou de maneira mais específica: a utilização deste material revela uma atribuição positiva de valor deste poema pelo filme ou, ao contrário, pode ser entendido dentro de uma chave irônica e de sutil desqualificação?

Para responder estas questões, é interessante um olhar mais amplo sobre a Caravana, na qual a incorporação de elementos da cultura popular nordestina, como a literatura de cordel, está presente de maneira extensiva. Em primeiro lugar, essa presença recorrente precisa ser analisada dentro do contexto da discussão sobre o nacional-popular no cinema, na década de 60. A idéia de se fazer um cinema popular (que se dirija ao povo) com matéria prima popular (que vem do povo), por exemplo, é marcante no primeiro Cinema Novo. Assim, neste momento histórico, o uso de elementos da cultura popular no cinema é observado de forma constante e se relaciona estreitamente com o desejo de fazer um cinema popular. No entanto, invariavelmente, essa matéria prima precisaria ser re-elaborada criticamente, uma vez que o conteúdo da produção popular é entendido como alienado ou alienante. ${ }^{62}$

Este processo de transposição crítica pode ser observado inúmeras vezes nos filmes da Caravana e, no caso específico de "Viva Cariri!", se coloca de maneira ambígua. Em resposta à pergunta inicial é possível dizer que, por um lado, o aspecto ingênuo e alienado da cultura popular é ressaltado a partir do contraste radical entre banda sonora e imagem. Por outro lado, o efeito produzido é de ironia. Obviamente, o comentário irônico construído na montagem é do narrador. No entanto, num momento do documentário em que o enunciador parece apagado como é o caso aqui - e a cena adquire certa autonomia, o cantador parece também se impregnar de um olhar irônico em relação ao mundo que o cerca. ${ }^{63}$

\footnotetext{
${ }^{62}$ Ver BERNARDET, GALVÃO, 1983.

${ }^{63} \mathrm{O}$ contraste entre o Pais de São Saruê e a bem menos próspera realidade nordestina é também utilizado por Vladimir de Carvalho no documentário de mesmo nome, produzido entre 1966 e 1970, finalizado em 1971, mas lançado apenas em 1979 devido à censura. Vladimir filma a região de Rio do Peixe, no sertão paraibano, e enfoca a relação do homem com o sertão através dos três reinos da natureza - vegetal, animal e mineral. O contraste entre as potencialidades do sertão e a miséria que concretamente o assola é sintetizado no título do filme, que se refere ao mesmo cordel utilizado por Sarno, de autoria de Manoel Camilo dos Santos.
} 
Quando o documentário se encaminha para o final, aos 32 minutos, a música retorna. Inicialmente, a voz do cantador está em off e vemos novas imagens aéreas do Vale do Cariri; suas áreas verdes e seus morros. Em seguida, o cantador é apresentado. Ele toca sua viola e canta na calçada de uma rua de Juazeiro, cercado por pessoas. A riqueza de São Saruê, continua sendo descrita: "O povo de São Saruê/ todos têm felicidade/ passa bem anda decente/ lá não há contrariedade/ vivem sem trabalhar, pois têm dinheiro à vontade/ Lá os tijolos das casas são de cristal e marfim/ as portas barras de prata / fechaduras de rubim / as telhas folhas de ouro/ e o piso de cetim".

Nesta segunda entrada, a origem do discurso se revela. Trata-se de um cantador e seu discurso é aquele do imaginário popular. Explicita-se o contraponto entre a realidade do Vale do Cariri, com a qual nos confrontamos ao longo do documentário - marcada pela pobreza e pela decadência econômica -, e a realidade idílica deste país imaginário. A situação de pobreza não se reverte em termos de mobilização no plano concreto, em participação política, mas é sublimada através da esperança numa realidade utópica, neste lugar que não é o Cariri.

Este efeito crítico em relação à sublimação da pobreza através da esperança é ainda mais acentuado no término da seqüência, quando o final do áudio do cantador é coberto por uma imagem reversa em que Cícero - o penitente que carregou uma cruz de madeira de 70 quilos de Caruaru até Juazeiro do Norte - é acompanhado, ao chegar em Juazeiro, por uma multidão. Com a reversão da imagem vemos a massa andando para trás, as idéias de atraso e de estagnação surgem com força.

A situação do penitente, que tem neste momento seu clímax, é desenvolvida ao longo de outras cinco seqüências que antecedem esse ponto máximo de tensão. Nessas cenas anteriores, o que está sendo classificado de discurso não personalizado é construído a partir de dois elementos. $\mathrm{O}$ primeiro é a mediação do cordel que funciona como comentário informativo e dispensa a 
interferência do locutor. O segundo é que, em todas as seqüências envolvendo Cícero, a câmera está afastada da ação, fora da cena, numa posição de observação distanciada de um evento que reúne centenas de pessoas. Trata-se de uma situação pela qual nem a câmera, nem a equipe, são responsáveis. Novamente, os "fatos parecem se reportar a eles mesmos", e neste sentido o discurso produzido estaria sendo simplesmente revelado.

Em sua primeira aparição, Cícero está dentro de uma igreja lotada, ao lado do padre. Em off, a voz do padre apresenta Cícero e pede a ele que diga algo. Cícero responde: "O que eu quero dizer a todos que me prestigiaram, me faltaram com o respeito, que me contribuíram, aqueles que me chamaram de ladrão, Deus o proteja a todos, dê saúde e felicidade (...)”. O padre complementa: "Estamos vendo que o senhor Cícero Marques é um homem que nos dá o exemplo da penitência". Neste ponto, entra o áudio de um cantador que vai, em forma de cordel, contar a história de Cícero, enquanto vemos imagens da multidão reunida em frente à igreja e do penitente andando até a cruz, colocando-a nas costas e sendo cercado por muitas pessoas.

Nesta seqüência, estão presentes elementos que vão caracterizar todas as entradas de Cícero. Além da já citada mediação do cordel, nota-se que em todas as cenas que o envolvem, som e imagem nunca estão em sincronia e as imagens nunca têm som ambiente. Este deslocamento entre som e imagem gera um efeito não naturalista, bem como uma certa desarticulação aparente do sentido.

Este efeito é acentuado pelo uso de algumas superposições sonoras. A terceira aparição de Cícero, por exemplo, acontece logo após uma seqüência em que se escuta o áudio de um discurso político cuja origem não é identificada. Vemos um plano geral do padre falando em frente ao altar, numa imagem sem som ambiente. Ele tem o penitente à sua frente, está cercado por uma multidão de fiéis e gesticula. Por alguns segundos temos uma superposição do áudio do 
padre e do político da seqüência anterior. Criando uma certa confusão de vozes, a montagem acaba aproximando o discurso do padre ao discurso político.

Penitência e a obediência são ressaltadas no sermão: "Sr. Cícero Marques agradecemos ter recebido esta visita tão importante, este exemplo de penitência que o senhor nos dá. E aqui o senhor vem terminar sua penitência no túmulo daquele que também nos dava o exemplo da mortificação. Aquele que sofria e entregava seu sofrimento ao senhor pelo bem da humanidade (...)". O exemplo de mortificação ao qual o padre se refere é o de Padre Cícero, que novamente manifesta sua onipresença difusa na forma de uma imagem de arquivo. Além de ilustrar o discurso do padre, essa inserção surge justamente quando o duplo papel da igreja - de liderança política e religiosa - está sendo sugerido pela montagem. Como visto anteriormente, Padre Cícero é neste sentido reiteradamente apresentado - seja pelo comentário, pelos depoimentos ou pela montagem - como uma figura emblemática deste múltiplo poder do líder religioso.

Como em todas as outras aparições de Cícero, as falas do padre não se dirigem diretamente à equipe ou ao espectador; são falas dirigidas à multidão que acompanha a trajetória do penitente. É o discurso religioso- aparentemente sem filtros - agindo sobre a massa alienada. Como no caso da beata, as seqüências de Cícero caminham para um afastamento cada vez maior do naturalismo e na direção de uma representação alegórica da alienação. Isto chega ao ápice nas duas últimas seqüências nas quais Cícero é acompanhado por uma multidão e, quando o movimento da cena é invertido ${ }^{64}$, vemos todos caminharem para trás. O antinaturalismo é reforçado pela banda sonora. Mais uma vez, o som ambiente não é utilizado, e ouvimos gritos e tiros. "A religião impede o processo de conscientização desta massa" é o que parece nos dizer o narrador, através destas intervenções decisivas no som e na imagem.

\footnotetext{
${ }^{64}$ Num debate reproduzido pela Cinemais, Sarno falou sobre a seqüência em que as pessoas andam para trás em "Viva Cariri!". No dia da filmagem ele havia consultado Affonso Beato sobre a possibilidade de segurar a câmera de cabeça para baixo, pois lhe era mais confortável. Affonso disse que não haveria problema, mas, na copiagem, viu-se que a imagem não ficara normal. Tentaram várias vezes devolver o copião ao laboratório, mas acabaram por incorporar as imagens ao documentário. Sarno diz: "No andamento da montagem, quando a ruptura com o realismo e o naturalismo no documentário passa a ser central no filme, recuperamos as cenas, inclusive com um tratamento sonoro que acentua em extremo o anti-realismo desejado: tiroteio, gritos, etc." CINEMAIS, n. 28.
} 
Vale aqui abrir um pequeno parêntese para uma análise mais aprofundada da seqüência de fechamento do documentário que começa com a voz do cantador do sonho de São Saruê, passa pela marcha invertida de Cícero (citada acima) e continua na fala do fazendeiro, retomando a frase da abertura do filme - "os mistérios que porventura existem no nordeste". Após esta fala, vemos uma multidão cercando uma estátua de Padre Cícero, numa longa cena de enterro, sem som ambiente. A câmera mostra o caixão aberto visto de cima; o caixão fechado sendo enterrado; as pessoas cobrindo o caixão com terra e fincando uma cruz de madeira; mulheres enfeitando o túmulo com plantas e, finalmente, uma menina fincando uma vela.

A partir da marcha invertida de Cícero, passando pela cena do enterro, a promessa de prosperidade e felicidade anunciada pelo cantador começa a ser desconstruída. Esse processo de negação do sonho se completa na cena final. Nela, uma velha senhora come farinha de mandioca vagarosamente, olhando para o nada. Em termos objetivos ele parece não se importar em absoluto com a presença da câmera, mas levando-se em conta o percurso do filme até esse ponto, a cena sugere também um descolamento mais abrangente desta senhora em relação, não apenas a esta equipe específica, mas ao mundo em que vive.

Assim como o imaginário popular surge na voz do cantador e o discurso da penitência surge através de Cícero, o documentário dá voz também ao discurso político oficial, na vigésima quinta seqüência. Através de alguns dos procedimentos já identificados; a seqüência em questão debocha do discurso político. Inicialmente se vê a imagem de placas que já apareceram anteriormente: "Sudene colabora com este empreendimento", "Cimasa". Esta repetição de imagens reforça o peso destes textos e é, neste momento, bastante irônica, uma vez que a seqüência está colocada logo após o depoimento do representante da Cimasa. Neste ponto do documentário, já sabemos que a Sudene não está colaborando com os empreendimentos do Cariri e que a fábrica faliu. 
Na banda sonora permanece uma música de bandinha militar ao longo de toda a seqüência. Sobre imagens de autoridades desembarcando num aeroporto da Região do Cariri, sem nenhum som ambiente, entra em off o áudio de um discurso político. O discurso não é identificado e não é nítido, mas é possível perceber que se trata de uma autoridade local recebendo um representante do Banco do Brasil e exaltando o desenvolvimento da região. Entre outras coisas, ele diz que "o nordeste brasileiro, até dez anos atrás uma das regiões mais paupérrimas do mundo" conseguiu resolver seus problemas em relação a investimentos, proporcionando uma vida melhor para sua população. Agradece ao Banco pelo incentivo à fundação de empresas como a Cimasa. O discurso, que está em off, vai sendo coberto por imagens sem som ambiente de pequenos desfiles de autoridades: homens de terno se cumprimentam; eles andam na pista do aeroporto; autoridades cortam uma faixa e um dos homens discursa. O último plano mostra um padre ao lado das autoridades e antecipa o áudio da próxima seqüência, que é justamente o sermão do padre analisado acima.

Toda a seqüência parece ironizar o discurso oficial em relação à região. As autoridades desfilam numa analogia à procissão de Cícero. Em termos da banda sonora, tanto a música quanto o discurso tem um tom oficial. Ao mesmo tempo, o filme questiona a autoridade desses dois elementos, ao tirar a sincronia entre som e imagem. Com isso, o discurso do político perde parte de sua objetividade e a cena como um todo ganha nuances pouco naturalistas. Além disso, a origem do discurso não é identificada, assim como nenhuma das autoridades retratadas, criando uma impressão de anonimato muito favorável a generalizações. Vemos um "doutor" qualquer e uma "ilustre comitiva" qualquer. Ou seja, são muitas vozes e muitas autoridades, mas ao mesmo tempo poderiam ser qualquer voz e qualquer autoridade.

Colocando os discursos não personalizados ao lado dos discursos autônomos, dos dirigidos e da locução, completa-se a caracterização dos principais modos de enunciação do documentário. A descrição dos múltiplos procedimentos, através dos quais as diferentes vozes presentes em "Viva Cariri!" se relacionam gerando significados, procura desconstruir a sensação que o espectador 
tem ao assistir o documentário: a de que - tanto pela composição das cenas, quanto pela montagem - estaria diante de um discurso fragmentário. Parece importante discutir se estes momentos de distensão da presença do locutor ou de um maior afrouxamento do encadeamento discursivo, não têm justamente o efeito contrário, isto é, o de contribuírem fortemente para a afirmação clara da voz do texto. Em suma, tratar-se-ia de um relaxamento calculado.

Na montagem, além da alternância entre os pólos religioso e econômico - com a inserção de seqüências autônomas que se colocam de forma híbrida entre estes dois eixos - existe também uma alternância de estilos. De um lado estão as seqüências em que a locução funciona como elemento estruturante e a imagem ilustra os conteúdos apresentados por ela. De outro, estão as seqüências sem locutor, nas quais a câmera trabalha de um modo mais observacional e pouco interferente. São seqüências longas e cujo sentido - dentro da linha de raciocínio desenvolvida pelo filme - é construído na montagem.

Documentário de transição, "Viva Cariri!" escapa da rigidez do "modelo sociológico" de "Viramundo", sem entretanto abrir mão de um olhar externo autorizado e de uma análise crítica da realidade observada. A crescente "falta de coesão" do documentário - que caminha em sentido mais e mais antinaturalista, culminando na inversão da imagem do penitente que caminha - é ilusória. Nos contrastes e nas relações que se estabelecem entre seqüências teoricamente desconexas e independentes constrói-se a tese apresentada pelo filme. $\mathrm{Na}$ decadência do Vale do Cariri, a modernização bate de frente com os resíduos - mistérios - da cultura popular e de um modelo de organização social e econômica, onde religião e política revelam-se como duas faces de um mesmo modo de dominação. Nesse contexto infinitamente distante do sonho popular cantado pelo violeiro, alguns têm muito pouco e depositam todas as suas esperanças na redenção através da fé, que, o narrador nos afirma de maneira indireta, não virá. 


\section{CAPÍTULO 3 | "FREI DAMIÃO" E O LOCUTOR INVISÍVEL}

Enquanto "Viva Cariri!" aborda a religiosidade do Vale do Cariri de um ponto de vista generalizante, como elemento fundamental para uma análise global da cultura popular nordestina e das questões sócio-econômicas da região no final da década de 60, "Frei Damião: Trombeta dos Aflitos, Martelo dos Hereges" (cor, 19 minutos, 16mm, 1970) trata da religiosidade nordestina a partir de um recorte bem específico: o fanatismo religioso.

O curta-metragem é um dos seis documentários dirigidos por Paulo Gil Soares na Caravana Farkas, filmados na Paraíba e no Recôncavo Baiano: “A Mão do Homem” (1969/1970), “A Morte do Boi” (1970), “A Vaquejada” (1970), “Frei Damião: Trombeta dos Aflitos, Martelo dos Hereges" (1970), “Jaramataia” (1970) “O Homem de Couro" (1970). Entre os três diretores, Paulo Gil talvez tenha sido o que melhor delimitou tematicamente sua leva de produção. Com exceção do próprio "Frei Damião", todos os filmes abordam diferentes aspectos do ciclo do gado: a economia da carne, a economia do couro, a figura do vaqueiro e a vaquejada.

“A Mão do Homem”, por exemplo - filmado no interior da Paraíba e dedicado a Lina Bo Bardi fala sobre o artesanato de couro, a partir de exemplos da produção de selas e chapéus, articulando uma locução em off e entrevistas com produtores que afirmam serem os negociantes os únicos a levarem vantagem nesse processo produtivo. Diferentemente das monografias de Sarno, o documentário não se atém ao registro de um caso particular que poderia ser generalizado, mas procura uma visão mais ampla do processo de produção. A análise apresentada pelo filme é resumida na seguinte locução, bastante representativa do olhar da Caravana sobre o tema: "Um artesanato ditado pelo útil e pelo necessário, constituído pelo valor de produção (...) uma produção para a qual o próprio artesão não está preparado, não tem condições de consumi-la”. 
"A Morte do Boi”, foca um outro aspecto da mesma cadeia: o abate do boi no interior da Bahia e os diferentes aproveitamentos de sua carne e seus derivados. Assim como os dois outros diretores da Caravana, Paulo Gil busca incorporar ao filme elementos da cultura popular nordestina como a xilogravura - usada mais de uma vez nos créditos iniciais destes documentários -, as cantorias, os pífanos - usados na trilha sonora de diversos filmes -, e a poesia de cordel, muitas vezes utilizada na narração em off.

"Jaramataia" - nome dado ao gado adaptado ao sertão - tem por sua vez como foco uma fazenda homônima, no interior da Paraíba. Através de entrevistas com o proprietário e com trabalhadores do local, o filme apresenta diversas atividades relacionadas ao gado que acontecem ali: a produção de queijo coalho, de manteiga, e o trabalho de vaqueiros. A figura do vaqueiro é retomada em dois outros filmes: "O Homem de Couro", que acompanha um vaqueiro chamado Zé Galego, e "A Vaquejada", no qual a vida do vaqueiro é abordada a partir de um de seus "poucos momentos lúdicos", como afirma o narrador, logo no início do filme. $\mathrm{Na}$ vaquejada, os vaqueiros competem tentando derrubar um boi pela cauda, enquanto cavalgam. A necessidade, que pauta a relação cotidiana do vaqueiro com o gado, é momentaneamente substituída pelo desejo, pelo desafio e pela vivência de uma posição de poder.

"Frei Damião" diferencia-se destes documentários não somente pelo tema, mas também por questões formais que o tornam mais relevante para esta análise. Enquanto nesses cinco primeiros documentários a voz do narrador tem um caráter estruturante, e o ponto de vista do diretor se constrói de maneira bastante explícita - seja através na narração, seja através da combinação de narração e depoimentos -, em "Frei Damião" a presença do locutor é sensivelmente reduzida e não tem a função de expor a tese de fundo do documentário.

O filme acompanha uma visita de Frei Damião - beato tido por muitos como um santo - a Taperoá, Paraíba em 1969. A narração em off é usada no começo do filme, para informar o espectador da visita de Frei Damião à cidade e introduzir a figura do religioso como um 
fenômeno do "beatismo", termo que em si carrega uma conotação pejorativa ligada, segundo definição do Dicionário Houaiss ${ }^{65}$ a uma "devoção exagerada, fingida ou afetada, freqüentemente perdendo-se em excessivas manifestações formais e/ou supersticiosas”.

A partir deste ponto, o filme procura responder quem é Frei Damião, através da articulação de depoimentos de fiéis e do próprio Frei, além de imagens do religioso em ação. Enquanto nos depoimentos de fiéis a voz do realizador não está presente, na entrevista do Frei ela se afirma, gerando um embate ideológico explícito com o religioso, que evolui de um duplo movimento de sedução para o confronto aberto e que pretende desmascarar a persona pública do frei. O resultado é uma forte crítica ao fanatismo criado em torno da figura do beato, construída pela montagem.

O que nos interessa em especial no filme é seu afastamento dos parâmetros de um certo documentário expositivo de vocação sociológica - organizado a partir da voz em off autoritária, e popular na primeira metade da década de sessenta no Brasil - não observado nos outros cinco filmes de Paulo Gil. Ao tirar do comentário a função de organizar o material fílmico e ao aumentar a presença da entrevista, entre outras coisas, o documentário se aproxima de algumas tendências de transição, esboçadas na análise de "Viva Cariri!", operando entre as fronteiras da "voz do dono" e da "voz do outro".

Há, de um lado, a tese de fundo, altamente crítica à religião e coerente com uma posição que prevalece unânime nos documentários da Caravana. No entanto, o documentário não se resume ao que poderia ser classificado como filme de tese. "Frei Damião" traz algumas novidades em relação ao dito "modelo sociológico", como a presença da "religião subjetiva" através de vivências religiosas pessoais - embora o registro do rito coletivo ainda exista, e a associação entre religião e forças socioeconômicas dominantes seja constantemente sugerida-, a retração

\footnotetext{
${ }^{65}$ Segundo o Houaiss o significado de "beatismo" corresponde ao de "beatice", cujo verbete encontra-se acima transcrito. Ver página 21 do Dicionário Houaiss da Língua Portuguesa / Antônio Houaiss e Mauro de Salles Villar. Rio de Janeiro. Objetiva. 2001.
} 
do comentário e a forte participação de entrevistas, que na década de 70 se tornariam mais populares. $^{66}$

Para aprofundar essa análise retomo aqui a definição do conceito de "voz do texto" elaborado por Nichols ${ }^{67}$. Como já discutido, para ele, a voz do texto - que não corresponde à voz literal do autor $^{68}$-, é um padrão intangível formado pela interação de todos os códigos de um filme, ou seja, a maneira como o filme organiza aquilo que apresenta. De seu ponto de vista, esta questão é central para a disputa de formas na evolução do documentário: do estilo de discurso direto de Grierson (em que a exposição da tese se organiza a partir de uma narração em off supostamente autorizada e quase sempre arrogante); passando pelo cinema direto norte-americano, que suprime completamente comentário e entrevistas despertando dúvidas sobre o ponto de vista do autor; às novas formas que estas questões tomam na década de 70. Para Nichols, as diferentes tradições do documentário buscam constantemente novas estratégias ligadas à voz textual para representar "as coisas como elas são".

Ainda que a sistematização histórica de Nichols deva ser aplicada com reservas ao contexto brasileiro, onde esta periodização é certamente menos nítida, suas sugestões jogam luzes interessantes ao debate sobre o status da voz do texto em "Frei Damião". Partindo-se de uma possível relação de identidade entre a tradição griersoniana e os documentários que se enquadram no dito "modelo sociológico", é possível propor uma aproximação entre as vozes de autoridade que se fazem presentes nestas duas tendências. De qualquer forma independentemente de qual o documentário expositivo a ser usado como parâmetro - parece correto dizer que a locução em off de "Frei Damião" se liberta do paradigma sociológico,

\footnotetext{
${ }^{66}$ Ver MESQUITA, 2006.

${ }^{67}$ Ver NICHOLS, 2005.

${ }^{68}$ Nichols usa a expressão "voz literal” para se referir à presença concreta da voz do próprio autor no filme, seja no comentário ou numa situação de entrevista, em que a presença do realizador é assumida e suas perguntas são ouvidas pelo espectador. O uso do termo "literal" tem a função de diferenciar a voz física do autor e a "voz do texto", que representaria a maneira através da qual o autor expressa seu ponto de vista. Ou seja, mais do que como um conceito, a expressão pode ser entendida ao pé da letra.
} 
abrindo mão da dominação total da voz textual, e incorporando técnicas observacionais do cinema direto, especialmente no registro das manifestações religiosas.

Abre-se espaço, então, para investigar uma segunda questão: como se dá este momentâneo apagamento da voz do texto, correlato à oposição enunciador fictício/ enunciador real proposta por Odin? Qual sua relação com o aumento da sensação de acompanharmos a realidade como ela é? Finalmente, devem ser exploradas as considerações de Nichols sobre a relação que se estabelece na década de 70 entre a voz do texto e os testemunhos pessoais; quando os cineastas restituem a enunciação direta através de entrevistas que, apesar de serem ainda cúmplices da voz do texto, têm sobre o espectador um efeito distinto daquele do comentário autoritário. Ao contrário do risco apontado por Nichols de que a hierarquia entre as vozes seja perdida e a voz do texto endosse de maneira acrítica os personagens, um questionamento sobre como se dá a hierarquização de vozes em "Frei Damião" aponta para uma dominação nítida da voz do texto em relação às vozes dos depoentes.

De antemão, este simples levantamento de questões parece apontar, de maneira clara, que o filme navega entre tendências diversas, num movimento transicional em relação a dois pólos já mencionados, a "voz do dono" e a "voz do outro". De qualquer forma, para responder às questões propostas acima, faz-se necessária uma análise mais cuidadosa do encadeamento discursivo da montagem, para construção do argumento central do filme. De maneira geral, a estrutura do filme, que tem 28 seqüências temáticas, pode ser dividida em três grandes blocos abertura, desenvolvimento e conclusão -, apesar dessa nomenclatura não ter qualquer conexão com o formato do cinema narrativo dramático.

A abertura tem pouco mais de dois minutos de duração e começa com a apresentação da personagem que denominaremos como "devota fanática" (conforme justificativa apresentada no próximo item) e que irá ressurgir diversas vezes ao longo do documentário, atuando como uma espécie de fio condutor. Em seguida, entram os créditos iniciais e, depois, há uma seqüência em 
que o comentário apresenta Taperoá, a figura de Frei Damião e coloca a pergunta que o desenvolvimento buscará responder: “Mas quem é Frei Damião?”.

O desenvolvimento do documentário, com aproximadamente dez minutos e meio de duração, pode ser subdividido em dois grandes momentos. As primeiras nove seqüências, das vinte que constituem o bloco, têm depoimentos de populares, respondendo à pergunta formulada na abertura e apresentando histórias de milagres realizados pelo Frei. Deste ponto em diante, os depoimentos são substituídos por um olhar mais direto em relação a ele: seqüências que o mostram em ação (pregações, procissões e interações com os fiéis), e outras, de entrevista com ele próprio, o personagem principal.

O fechamento do documentário acontece nas três últimas seqüências dos filmes nas quais se apresenta o que seria a resposta do documentário à sua pergunta inicial: o fenômeno de Frei Damião é mais um exemplo do fanatismo religioso e, apesar da resistência do Frei em admiti-lo, o fanatismo é interessante para a Igreja enquanto instituição.

\section{ENCADEAMENTO DISCURSIVO}

\section{QUEM É FREI DAMIÃO?}

Enquanto em "Viva Cariri!" Padre Cícero é uma memória e um mistério tangenciado por Geraldo Sarno, Frei Damião é vivo e está em plena atividade, quando este documentário foi realizado em 1969. Desta forma os questionamentos e o argumento de Paulo Gil se constroem a partir de um confronto direto com esse novo fenômeno do beatismo. Esta aproximação ao fenômeno, entretanto, não se dá de maneira direta e imediata no documentário. O primeiro contato é feito através de uma locução em off, que apresenta, de maneira distanciada e irônica, a figura de Frei Damião. 
O documentário tem início com a apresentação inicial da devota fanática, personagem que retornará muitas vezes ao longo do filme. Vestida de preto com óculos de armação grossa - a imagem típica da beata - ela aparece pela primeira vez sentada em uma calçada cantando: "Senhor Deus, pela vossa sagrada paixão e morte, misericórdia...”. Este pedido de clemência divina voltará na cena final do documentário, onde a devota está presente novamente.

A opção por identificar essa personagem como fanática não tem a intenção de estabelecer um juízo negativo de valor em relação a ela. Ao contrário, o uso desta nomenclatura busca explicitar o mecanismo de tipificação utilizado pelo autor. A personagem é reduzida pelo filme a seu aspecto de fé exacerbada, funcionando como uma personagem típica e corporificando o fenômeno do fanatismo que é discutido ao longo do documentário. Essa operação é feita, entretanto, de modo bastante engenhoso e ambíguo, uma vez que esta personagem-exemplo assume por vezes o papel de fio condutor da narração. Ou seja, apesar de possuir um status organizador, a devota está - ainda que não saiba disso - completamente submetida à autoridade da voz textual, que a classifica através da montagem. Vale acrescentar que o efeito de tipificação é acentuado pelo fato do documentário não creditar essa mulher com letreiros (nem qualquer um dos entrevistados populares). Ao desenvolvimento do filme, não importa qual seu nome, sua profissão ou sua idade, uma vez que a função narrativa desta personagem está ligada a somente um dos aspectos de sua personalidade: a devoção exagerada. Isto é claramente colocado em foco pelo filme, de forma a apresentá-la unicamente como um exemplo do fanatismo em relação ao Frei.

Logo após a primeira aparição da beata, entram os créditos iniciais, que assim como em outros documentários da série, incorporam elementos da cultura popular nordestina - neste caso as ilustrações de cordel e a trilha sonora de Banda de Pífanos de Caruaru como fundo musical. $\mathrm{Na}$ seqüência, tem início a abertura propriamente dita do filme. É o único momento, no documentário todo, em que existe a presença da locução em off, situando aqui os limites do 
filme e apresentando sua situação chave: uma visita de Frei Damião à cidade de Taperoá, na Paraíba, em 1969.

Uma voz em off anuncia, inicialmente sobre imagens gerais de Taperoá e, depois, sobre imagens da visita do Frei à cidade: “Taperoá, Paraíba, 1969, um aviso mágico corre pelas estradas e ruas e atinge cada casa: Frei Damião chegará trazendo a paz para os bons e o fogo eterno para os impuros". O comentário inicial aparentemente endossa o fenômeno do Frei, apresentado como um novo messias e uma atualização histórica de Antônio Conselheiro e Padre Cícero: "Nordeste, 1969, a memória de velhos beatos e taumaturgos revive nas ruas de uma cidade paraibana; revive-se o clima de misticismo que antes gerou Conselheiro e Padre Cícero. Vive-se o beatismo. Frei Damião de Bozano da ordem dos frades menores de São Francisco Capuchinho, chegado ao Brasil em 1931, época em que iniciou seu apostolado pelos sertões nordestinos, um novo messias para o povo. A trombeta dos aflitos, o martelo dos hereges. (...) Mas quem é Frei Damião?”.

As imagens da visita do Frei à Taperoá, que ilustram o comentário, ressaltam ainda a enorme mobilização popular em torno da figura do beato. Vários planos mostram o Frei sendo acompanhado por uma multidão: o empurra-empurra para entrar na igreja, a chegada de fiéis de ônibus, etc. Desta forma, a locução não questiona diretamente, num primeiro momento, a sua posição de messias. “Sim”, afirma, Frei Damião está chegando trazendo a paz para os bons e o fogo eterno para os impuros.

No entanto, é justamente na excessiva reiteração do poder místico de Frei Damião, que se esconde a ironia. Expressões como "um aviso mágico", "um novo messias", ou até mesmo "a trombeta dos aflitos, o martelo dos hereges", associadas à conotação pejorativa do termo "beatismo", deixam transparecer uma crítica sutil, que será construída no desenvolvimento do documentário. Esta ironia se torna ainda mais clara quando considerada a pergunta final da locução: “mas quem é Frei Damião?”. Apesar de não desqualificar as afirmações anteriores, a 
pergunta sugere que, para além do rótulo de messias associado ao Frei, existe uma figura real que talvez não corresponda ao rótulo e que será investigada.

Desta forma, reforça-se a alteração no perfil da locução do documentário em relação à voz em off autorizada, uma vez que aqui o locutor se abstém de apresentar a tese. O comentário inicial e único em off de todo o filme - apresenta o contexto geral com ironia sem, no entanto, propor com clareza qualquer premissa crítica. A abertura coloca, ao invés de uma hipótese a ser confirmada, uma pergunta a ser respondida no desenvolvimento, pela afirmação da voz textual na condenação ao fanatismo.

\section{FREI DAMIÃO TEM PODERES DE SANTO: ELE PREMIA E PUNE}

O desenvolvimento começa com o retorno da personagem fanática, que parece responder diretamente à pergunta formulada pela seqüência anterior. Na mesma locação de sua primeira fala, ela afirma que "Frei Damião só tem dois cantos para olhar, o chão e o céu", no primeiro de uma série de testemunhos populares que - também se relacionando com a pergunta inicial do locutor - justificam a condição de messias do Frei, através de pequenas narrações dos milagres atribuídos a ele.

É neste ponto que a devota fanática assume seu papel de organizadora das diversas vozes dos entrevistados. Apesar do controle da voz do texto estar claramente na montagem, é ela quem aparentemente conduz o fluxo discursivo desse bloco. A beata anuncia o que se verá na seqüência, atuando como entrevistadora e mediadora da realidade num momento em que a voz literal do autor está absolutamente ausente. Bastante confortável no papel de condutora, assume esse personagem de forma convicta, sem imaginar que a montagem não lhe será solidária. Parece se relacionar com o filme como um projeto que, de fato, busca demonstrar a santidade e o poder de Frei Damião, e não desmascará-lo, colocando-se assim de maneira participativa 
nessa missão. Em suma, a voz do texto apropria-se da voz da fanática, para afirmar-se à sua total revelia.

Não é possível saber até que ponto o autor é responsável por essa má-interpretação por parte da devota de qual é a real natureza do documentário, já que esta é uma questão de contexto e não imanente ao texto. As diversas participações da fanática no filme parecem, ao mesmo tempo, sugerir uma outra leitura possível da relação personagem-filme: a fanática vive em seu próprio universo simbólico, falando quase sempre para uma platéia imaginária, ao invés de dialogar com o entrevistador real que está a sua frente, como quem transmite aos ouvintes um conhecimento sagrado. Esta caracterização aproxima fanatismo e loucura, num procedimento comum também aos documentários de Sérgio Muniz e Geraldo Sarno. O documentário apresenta o fanatismo como - mais do que ignorância - um autismo em relação ao mundo, capaz de gerar uma tendência do beato a operar permanentemente na chave sacerdote/fiel, sem ao menos supor, que esta visão de mundo possa ser contestada.

Dessa forma, independente de sua motivação pessoal, seja dentro ou fora da cena, é a fanática que conduz todos os outros depoimentos do bloco, que repetem na verdade uma mesma afirmação: Frei Damião tem poderes de santo, ele pode premiar e punir. Sua primeira colocação, de que o Frei só olha para o céu e para o chão, é seguida pela fala de um senhor bem vestido, com a aparência de fazendeiro, contando que há mais de 30 anos ouve-se falar em Frei Damião, que, pelo que dizem suas palavras, "já foi um homem que veio com aquele destino para se santificar".

E assim como durante todo o bloco, os depoimentos de populares são intercalados por intervenções da fanática. Desta forma, logo após o fazendeiro, ela surge novamente - numa outra locação, que parece ser um centro religioso - e fala olhando diretamente para a câmera, num enquadramento centralizado, reiterando sua função de apresentadora: "Eu acredito nos milagres de Frei Damião porque conheço várias pessoas que foram beneficiados (sic)”. A função 
deste texto é justamente enunciar e apresentar os próximos conteúdos, ou seja, anunciar que, a partir desse ponto, os tais beneficiados serão apresentados.

Na seqüência seguinte, o primeiro milagre é narrado. A mediação que a fanática realiza entre filme e realidade observada se acentua, quando ela conduz uma entrevista com uma popular. As duas mulheres estão em pé, encostadas num batente de porta, e a fanática pede à outra que conte a graça que obteve de Frei Damião. A entrevistada conta que sua filha nasceu com uma doença, mas foi curada depois de ela ter pedido um milagre ao Frei.

Em todas as seqüências de narrações de milagres observam-se alguns procedimentos similares. A câmera está sempre posicionada de forma distante dos depoentes e estes, por sua vez, parecem em geral constrangidos e dizem textos pouco espontâneos, visivelmente decorados. A sensação que se cria é a de que os entrevistados foram completamente abandonados, em cena aberta, pelo autor, e têm que criar sozinhos, a partir de códigos audiovisuais que eles desconhecem, a melhor encenação possível para que suas histórias se tornem críveis. A voz literal do autor nunca está presente e a condução das entrevistas parece não passar por ele. Ajudados e orientados pela fanática, os depoentes contam suas histórias diretamente para a câmera, nunca para a equipe. Esta omissão e transferência de poder para a fanática têm a implicação ideológica clara de desresponsabilizar o diretor pela cena e, ao se omitir, ele lava suas mãos em relação ao que é apresentado.

Não se trata então, daquilo que Nichols classifica como endosso dos testemunhos apresentados sem contraponto crítico e com o apoio da montagem - pela voz textual do filme de entrevista. Aqui, os entrevistados, embora não sejam questionados pela voz literal do autor, não despertam qualquer solidariedade por parte da voz textual. O olhar da câmera não apóia os entrevistados. A chave, então, é a não identificação entre narrador e entrevistados. Ao contrário, estes são filmados de maneira a deslegitimar o conteúdo de suas falas; as imagens desconstroem os discursos. Evidencia-se o despreparo em relação à cena, e o mau-desempenho destes 
depoentes, enquanto atores naturais de seus próprios personagens. O que se observa é uma não coincidência de propósitos entre a aparente organizadora do discurso - a fanática, que também hierarquiza as vozes com o objetivo de comprovar sua própria tese de que Frei Damião é um santo - e o narrador efetivo do filme, que usa os depoimentos de populares como o pano de fundo que ilustra o fenômeno do fanatismo, preparando o verdadeiro embate que terá lugar no momento que Frei Damião entra em cena.

Deste ponto de vista, embora a "religião subjetiva" esteja presente no documentário através dos depoimentos populares, ela não aparece ainda na forma de um diálogo entre filme e entrevistados. Os depoimentos são ouvidos, mas não têm nenhuma influência sobre o resultado discursivo do filme. Trata-se de uma relação completamente diferente da que, por exemplo, Eduardo Coutinho estabelece com seus entrevistados em "Santo Forte", onde existe uma aceitação, sem julgamentos, do discurso por eles produzidos e onde a presença e o diálogo com o cineasta aparecem de maneira inteiramente assumida ${ }^{69}$. Além disso, desde as imagens iniciais de "Frei Damião", a "religião objetiva" também é retratada, ao registrar o comportamento das massas em relação ao frei, com a câmera fora da cena e, de fato, pretendendo revelar "as coisas como elas são".

A seqüência de depoimentos continua com uma devota que relata o milagre do rádio. Está dentro de uma casa de paredes brancas, atrás de uma meia-porta verde que deixa seu tronco visível. O plano é bem aberto e a câmera, que está posicionada longe da entrevistada, se aproxima, enquanto a mulher fala dirigindo-se a ela: "Certa vez, em minha casa, estava com meu rádio quebrado. Todos os vizinhos estavam ouvindo o sermão de Frei Damião. Eu não estava, fiquei com inveja. Aí fiz uma prece para Frei Damião. No mesmo rádio quebrado, depois, consegui ouvir o sermão de Frei Damião".

\footnotetext{
${ }^{69}$ Ver nota n. 13 do Capítulo 02 que remete a artigo onde Ismail Xavier discute a relação entre entrevistador e entrevistado, a partir da obra de Eduardo Coutinho. (XAVIER, 2003)
} 
Novamente, nota-se o artificialismo já comentado: seu tom é formal, o texto foi ensaiado e decorado e, ao invés de dialogar com o entrevistador, a personagem, num enquadramento centralizado, anuncia o milagre diretamente à câmera. Além disso, outro detalhe importante fica evidente nesta seqüência: a maior parte dos milagres relatados tem um caráter bastante prosaico. Não se tratam de grandes feitos, mas de coisas cotidianas, tais como verrugas que desaparecem, rádios que são consertados. Há algo de ridículo no que é mostrado, no sentido de se apresentar uma desproporção entre os poderes de santo atribuídos ao frei e os feitos supostamente realizados por ele. Alguém precisa de um santo para consertar um rádio?

Se do ponto de vista do texto como um todo, o sentido criado é o de ironia ou mesmo de ridicularização face à santidade do frei, a fanática, contudo, não desiste de comprovar a tese contrária. Logo após o depoimento do rádio ela ressurge, em sua primeira locação. Parecendo ignorar o desenvolvimento do discurso até este ponto - ao colocá-la na posição de mediadora, o documentário cria a sensação de que ela é onisciente e, acompanhando a montagem, sabe de tudo o que já foi dito pelas diversas vozes -, a fanática insiste: “A força de Frei Damião, o poder sobrenatural que ele tem, nós não sabemos explicar. Sentimos a força...”.

A esta intervenção seguem-se mais dois relatos de milagres. O primeiro é o de um senhor que, sentado atrás de uma mesa de cozinha, relata de maneira monocórdica e sem expressão uma outra graça prosaica do Frei: sua filha havia perdido uma aliança num poço próximo à sua casa, mas, após beijar a mão de Frei Damião, tomou um novo banho no poço e encontrou a jóia perdida. O segundo é relatado pela própria fanática. Ela olha para esquerda, como se falasse com alguém, talvez o entrevistador. Conta que seu sobrinho tinha um sério problema de verrugas, até que sua irmã conseguiu uma garrafinha com a água que Frei Damião havia usado para lavar o rosto; o menino se banhou com essa água; e então todas as suas verrugas desapareceram. O final de seu depoimento é coberto por um plano de Frei Damião sorrindo, olhando para câmera. Mais uma vez, indiretamente, é ela quem “antecipa” o que virá a seguir, já que este é o mesmo plano da entrevista do Frei, que surgirá algumas poucas seqüências adiante. 
Finalmente, fechando este primeiro bloco do desenvolvimento, surge o relato não de uma graça, mas de uma punição. O mesmo fazendeiro que atribuíra, algumas seqüências antes, a Frei Damião a missão de santificação, agora, num plano mais aberto, conta que um candidato a prefeito usou uma relíquia de Frei Damião sem o seu consentimento, e acabou perdendo as eleições.

É neste ponto, depois do longo pano de fundo em que o documentário apresenta a visão que o povo tem de Frei Damião - a de santificação -, que a montagem fornece a primeira indicação de um argumento central para o filme. A devoção a Frei Damião não está ligada apenas à atribuição de graças - prosaicas, ridículas, como sugeriu a montagem - realizadas por ele, mas também ao medo da punição. Para os populares, segundo o discurso articulado pelo documentário, Frei Damião é mesmo a "trombeta dos aflitos" e o "martelo dos hereges". Ele é mais que um beato; é quase um santo; e tem o poder de premiar ou punir qualquer um. Desta forma, subordinando os depoimentos à sua tese de fundo e relegando a argumentação ordenada pela fanática à ilustração do fenômeno, o narrador prepara o terreno para a hipótese levantada a seguir: o fanatismo é fruto da ignorância do povo e de seu medo do inferno. Analogamente, a devoção a Frei Damião é fruto do medo da punição, da mesma forma que o elogio da penitência surge, em "Viva Cariri!", como a redenção dos pecadores.

\section{FREI DAMIÃO EM AÇÃO}

Até este momento, o documentário teve dois estágios de aproximação ao fenômeno: a locução inicial, que ironicamente reproduz a visão popular à distância; e os testemunhos de populares, que apresentam, em discurso direto, a figura do Frei como um homem de poderes sobrenaturais. No segundo bloco do desenvolvimento, que tem início por volta dos oito minutos do filme, o documentário chega a seu núcleo central, que é o contato direto com o beato, sem a intermediação dos relatos. Frei Damião é confrontado diretamente, em uma situação de 
entrevista intercalada por imagens dele em ação. Em outros termos, o filme contrapõe uma discussão abstrata sobre o fanatismo - que é o tema da entrevista - e a observação direta do "fenômeno".

Se no bloco anterior o autor omite-se e a montagem não revela o contato direto entre realizador e entrevistados - transferindo para a personagem da fanática o ônus da mediação -, na entrevista com Frei Damião o autor entra em cena. Enquanto os testemunhos de populares não são diretamente questionados - ainda que a montagem seja atuante, no sentido de não apoiar a caracterização do Frei como milagreiro -, no contato com Frei Damião o questionamento existe e é central para o desenvolvimento do argumento.

Entre outras leituras possíveis dessa diferença de abordagens, é plausível afirmar que o realizador tira o povo da arena de debate. Em outras palavras, a fé do povo não precisa ser questionada diretamente. Os depoentes não são vistos pelo autor como adversários ideológicos que mereçam ser confrontados, já que seriam vítimas da sua própria ignorância. Trata-se de um olhar paternalista em relação a estes entrevistados. Isto não significa, contudo, que a "religião subjetiva" - ou seja, a subjetividade religiosa destes personagens - seja vista de maneira positiva, nem apresentada como um olhar aceitável em relação ao tema. Apesar disso, a falta de questionamento direto dos depoimentos populares aponta para uma legitimação da fé - fundada na falta de conhecimento e no medo da punição - como substrato da cultura popular.

Outro ponto significativo neste momento do filme é a diferenciação de duas posturas da câmera: dentro e fora da cena religiosa. O uso do termo "cena" ganha aqui a conotação de "encenação", de "dramaturgia teatral". No momento da entrevista, é o realizador que estabelece a mise-enscène: sua voz literal e a figura de Frei Damião assumem papéis antagônicos. Frei Damião, por sua vez, atualiza no momento da filmagem o personagem dramático criado por ele mesmo para representar a idealização de seu sujeito social - conforme conceito de "representação natural" definido por Santeiro - assumindo o papel de ator natural dentro do documentário. É 
fundamental apontar que, no momento da entrevista, Frei Damião sabe que se comunica com o universo externo à Igreja; sabe que não está dialogando com um fiel; e expõe sua visão de mundo católica para o autor, com quem não compartilha de um universo ideológico.

Ao mesmo tempo, a dinâmica da representação altera-se nas seqüências mais observacionais. Nestas situações, câmera e autor colocam-se de fora da cena religiosa - que tem sua própria dramaturgia - e observam o desenvolvimento de um outro teatro. Na cena religiosa as regras são outras. Quem estabelece a mise-en-scène é Frei Damião, na tripla função de dramaturgo, diretor e ator principal. Ele representa a si mesmo, mas sua persona religiosa é bem diversa daquela que ele assume na entrevista. Frei Damião fala com uma multidão de fiéis, com quem compartilha um mesmo universo ideológico, sobre os quais tem grande ascendência - e sabe disso-, e dos quais recebe toda sorte de manifestações de exaltação de sua figura. Da mesma forma, seus atores coadjuvantes e sua platéia, diferentemente da voz literal do autor, colocam-se na posição de ouvintes que não teriam o direito de questioná-lo.

As cenas observacionais de Frei Damião interagindo com a multidão - e a forma como são inseridas na montagem - estão diretamente relacionadas às seqüências do penitente Cícero, em "Viva Cariri!", nas quais a ação é observada de fora, existe um forte senso de narrativa e "os fatos parecem se reportar a eles mesmos". Assim como Odin observa que o modo ficcionalizante está ligado à ausência de um "eu de origem" ou ao apagamento do enunciador real, como é freqüente nas abordagens documentárias observacionais, também Nichols relaciona algumas técnicas observacionais diretamente a procedimentos da narrativa clássica.

Segundo ele, as sutis estratégias organizacionais do documentário de observação "tendem a atribuir ao material histórico significados que na verdade são resultado do estilo ou da 'voz' do filme, da mesma forma que as estratégias da ficção nos convidam a acreditar que a 'vida' é como o mundo imaginário habitado por seus personagens" ${ }^{70}$ Este tipo de documentário nos dá a

${ }^{70}$ Ver NICHOLS, 2005. P. 51 
impressão de revelar um mundo intocado pelo olhar da câmera. E mesmo o fato da câmera ser eventualmente percebida personagem retratado funciona como uma certificação de que em todos os outros momentos, "puramente observacionais", ela nos mostrou o que teríamos visto com nossos próprios olhos. Ele destaca também a forma como estrutura observacional apóia-se em alguns procedimentos da narrativa clássica, tais como a cronologia de causalidade evidente, os planos organizados em cenas dramaticamente reveladoras, e a busca de um bom desempenho de personagens que "representam a si mesmos".

Apesar de "Frei Damião" não poder ser considerado um documentário de observação, as estratégias observacionais estão bastante presentes nas imagens de Frei Damião em ação, o que, conforme sugerido por Nichols, tem relação estreita com a busca de um maior efeito de veracidade e com a diferenciação entre evidência e argumento. Dessa forma, estão contrapostas a máscara do beato - usada na relação com o realizador durante a entrevista em que nega sistematicamente o fanatismo - e a revelação, através das imagens observacionais, do fanatismo “como ele verdadeiramente é”. Em relação à voz textual, os dois momentos opõem uma situação na qual a voz literal do autor é marcadamente presente e um argumento parece estar sendo desenvolvido; e outra em que a voz do texto parece se apagar completamente, sugerindo que é própria realidade que fala ao espectador através do filme.

Entretanto, as estratégias organizacionais do documentário como um todo são bem mais visíveis e, assim como já vinha acontecendo até este ponto, a montagem tem absoluto controle da significação que o filme constrói. Neste bloco, as seqüências estão estreitamente ligadas umas às outras, num forte encadeamento discursivo. Muito freqüentemente, uma seqüência irá propor uma questão que será respondida, ou contraposta, pela seqüência seguinte.

O bloco tem início na décima terceira seqüência, em que vemos pela primeira vez um sermão de Frei Damião, numa igreja repleta de homens. Enquanto a câmera passeia pelos rostos atentos da platéia que lota a igreja - numa série de planos bem fechados que vão dos semblantes sérios dos 
fiéis até Frei Damião, num ponto mais alto - ouve-se ouve em off o sermão do Frei. Apesar de ser difícil entender tudo o que é dito é possível identificar o núcleo central das palavras do beato: o pecado relacionado a pensamentos libidinosos. Ele condena o consumo de revistas, livros e músicas pecaminosas. Até no casamento, o pecado deveria ser evitado. Se um casal não deseja ter filhos, deveria viver na castidade. Para o Frei, qualquer anticoncepcional é condenável, sendo contrário à lei divina.

O primeiro contato do filme com o Frei, portanto, enquadra-se na chave observacional e revela uma primeira visão do personagem, que certamente não é positiva ${ }^{71}$. Na relação com os fiéis que assistem seu sermão, Frei Damião se mostra absolutamente seguro dos seus preceitos e de sua orientação. Não há qualquer tipo de hesitação; sua voz é firme e seu discurso é ultraconservador. A devoção popular e a fé em seus milagres são deslegitimadas pelo contraste com a postura do próprio Frei: mesquinha e conscientemente dominadora nas pregações; e esquiva - ou até mesmo cínica - durante o diálogo com o realizador.

Esta atitude revela-se na seqüência seguinte, que é primeira situação de entrevista. Frei Damião está sentado em uma cadeira, numa varanda. Com o quadro centralizado, ele olha para câmera sorrindo, num plano fechado na altura dos ombros. O entrevistador não aparece em quadro, mas sua voz é ouvida com total nitidez - gerando, inclusive, dúvidas sobre se ela foi captada mesmo em som direto, ou se foi inserida na pós-produção. O entrevistador pergunta: “O povo de Taperoá diz que você é santo. O senhor aceita isso Frei Damião?”. Após alguns segundos de silêncio, sem tirar o sorriso do rosto, Frei Damião dá uma risada e fala: “É bondade do povo... é

\footnotetext{
${ }^{71}$ Como apresentado no Capítulo 1, os filmes da Caravana não foram realizados tendo em vista um público definido. Dessa forma, para sugerir formas de relacionamento entre espectador e texto, assumo como espectador possível o intelectual de esquerda do final da década de 60. Como apontado por Nichols, uma vez que, nos documentários observacionais, a voz do texto está aparentemente enfraquecida, criam-se leituras possíveis e não definitivas. Evidentemente, um devoto fervoroso ao assistir a cena do sermão, não classificará o Frei de mesquinho ou conservador. Ao mesmo tempo, como insiste Odin em sua abordagem semio-pragmática, o significado do filme não se depreende unicamente do texto, mas guarda fortes relações com o contexto de exibição. Sem pretender discutir o processo de significação no cinema documentário, tomo a liberdade de imaginar - tendo em vista um conhecimento de senso comum do contexto de recepção da obra - reações possíveis desse espectador imaginado, que certamente é representativo da média de espectadores obtida pelo documentário.
} 
bondade". Parecendo ignorar a negativa, o entrevistador insiste e pergunta qual é o caminho para se alcançar a santidade. O Frei, demora para responder; ri e, com cara de bobo, faz um aceno, como quem diz "deixa isso para lá"; mas não responde.

Nesta primeira seqüência já se caracteriza um contraste muito nítido entre as várias personas do frei. Na situação de entrevista, ele mantém um olhar distanciado, esquiva-se das perguntas e fazse de desentendido. Esta postura é bastante diferente da maneira assertiva, e por vezes autoritária, com que ele se coloca publicamente, como visto na seqüência anterior. Num primeiro momento, o que se observa em relação à dinâmica entrevistador/entrevistado é um jogo duplo de sedução. A voz do realizador parece provocá-lo, sugerindo que ele possa ser colocado na posição de milagreiro, e tenta fisgá-lo pela vaidade. O Frei não se trai. Ele demora a responder, sorri de maneira simpática, e descarta essa hipótese ("é bondade do povo, é bondade...”), embora se note alguma satisfação vaidosa em sua postura.

O entrevistador insiste: “O povo diz que o senhor realizou vários milagres. O senhor fez alguma coisa que possa ser considerada um milagre?". Sempre com um sorriso, o Frei mais uma vez não se deixa levar pelo convite de sedução e responde: "Não conheço não... Contam muitas coisas, mas é exagero do povo". Apesar da negativa a sensação criada é a de que, no fundo, ele próprio acredita que se tratem de milagres.

Esta também parece ser a posição do fiel que, na seqüência seguinte, "desmente” o Frei, dizendo que foi curado por ele. A seqüência relativamente longa, de quase um minuto, começa com um plano fechado no rosto do fiel que afirma: "Fui curado por Frei Damião". Num plano mais aberto, o homem, sentado numa rede, conta que estava desenganado e os próprios médicos achavam que ele não tinha mais jeito; mas foi curado pelo Frei. O final de seu depoimento é: "Ele disse que não era doutor, que era doutor das almas (...) que não dava remédio, que quem curava era a fé, que quem tivesse fé que tomasse um copo de água fria. Fui dormir aleijado e amanheci bom”. Após este testemunho, que reitera o ponto de vista da religiosidade popular e 
reafirma a posição santificada do Frei, o documentário volta a ele, na mesma locação, num plano mais fechado. O entrevistador pergunta: "O senhor concorda com isso?". O religioso, com seu sorriso constante e num estado meio ausente, responde que não concorda.

O diálogo entre Frei, fiéis e entrevistador é mediado e organizado pelo narrador, através de procedimentos explícitos: a seleção de cenas e imagens; os cortes bruscos; a divisão da entrevista do Frei em partes; e o estabelecimento de sentidos e de um discurso que não pertencem nem ao Frei, nem aos fiéis, mas sim ao autor. Nas seqüências descritas acima, por exemplo, a pergunta “o senhor concorda com isso?" revela uma instância de seleção altamente participativa. A frase é tirada de seu contexto inicial - não sabemos a que o entrevistador, de fato, referia-se no momento da filmagem - de modo a criar um efeito de diálogo aparente entre as seqüências, e questionar o Frei a respeito do testemunho que acabou de ser ouvido. Desta forma, a relação de sentido que se estabelece é entre a questão e o fiel que foi curado. É como se o entrevistador repetisse uma pergunta que já foi feita: "O senhor concorda com os fiéis que atribuem milagres a você?”. E, assim como o fiel “desmentiu” o Frei, este, por sua vez, reafirma sua negativa.

A articulação de sentido continua na próxima seqüência, que mostra uma situação de interação entre o Frei e fiéis. Ele está diante de uma fila de fiéis, que querem cumprimentá-lo. A mulher que está no primeiro lugar da fila, bem em frente ao Frei, diz para ele: "Tanto faz ser Frei Damião como Padre Cícero". Esta inserção, ao mesmo tempo em que volta a questionar a negativa do padre, antecipa o tema do próximo trecho da entrevista com o Frei, que é o de Padre Cícero, a figura símbolo do beatismo nordestino. Após esta rápida intervenção da montagem, a narração volta à entrevista. E aproveitando a deixa de sentido aberta pela fiel, o entrevistador pergunta ao Frei qual sua opinião a respeito de Padre Cícero. O Frei não encara diretamente à câmera. Olha para o lado sem se fixar num ponto determinado e a câmera fecha mais no seu rosto: "Era um padre... O povo fica um pouco fanatizado, mas não foi ele o autor do fanatismo não...”. 
Neste ponto, a entrevista evolui para um embate cada vez mais nítido e o diálogo começa a ficar desconfortável, provocando uma visível curva descendente no humor do Frei. Até este momento, não apenas o diálogo não havia mencionado diretamente o termo fanatismo, como não estava em jogo a responsabilidade por ele. O Frei atribuíra certas manifestações de devoção excessiva à bondade e ao exagero do povo. Agora, o entrevistador parece sugerir que Padre Cícero possa ser culpabilizado pelo misticismo que gerou, abrindo espaço para a responsabilização do próprio Frei pelo beatismo que o cerca. O entrevistador pergunta, então, a que ele atribui o fanatismo do povo; e ele afirma que o fanatismo é a religião mal-entendida. $\mathrm{O}$ entrevistador insiste no tema e pergunta quem é culpado por esta religião mal-entendida. O quadro abre um pouco e Frei Damião responde, ainda sorrindo e sem fixar o olhar, que a culpada “é a ignorância do povo, o povo em matéria de religião é um pouco ignorante".

A dinâmica de disputa continua e o entrevistador faz outra pergunta: "Mas não seria o medo do inferno que faz o povo se fanatizar e seguir atrás dos padres em quem ele acredita?”. Frei Damião está mais sério, abre um sorriso, olha para baixo e não responde. Diante desta pergunta central para o argumento do filme, Frei Damião não busca mais a sedução. Seu interlocutor já foi identificado como um adversário ideológico. A disputa é injusta, porque o entrevistador tem a seu lado a montagem, que intervém na cena e não permite que Frei Damião responda à acusação velada de que a igreja indiretamente incentiva o fanatismo. Do ponto de vista do espectador, Frei Damião ficou sem palavras. Mas não é possível determinar se o Frei de fato não respondeu à questão, ou se a intervenção da montagem o deixou mudo.

Isto remete novamente a nítida diferenciação nos procedimentos do autor em relação aos dois tipos de entrevista presentes no documentário - as do Frei e aquelas dos fiéis. Nos depoimentos populares, a situação de entrevista está descaracterizada. Toda a construção da situação vai no sentido de afastar o enunciador daqueles depoimentos, colocando os entrevistados numa situação de desconforto e ridicularizando sutilmente suas falas. Os testemunhos são posicionados pela lógica da montagem, mas, dentro de cada seqüência, as histórias são 
integralmente preservadas, com começo, meio e fim. Em relação ao Frei, a voz literal do autor é presente e inquiridora e a situação de entrevista é recortada na montagem de modo a reforçar pelos sentidos que se estabelecem entre as seqüências - o argumento construído pela voz textual.

Mais uma vez, interagindo diretamente com a instância de enunciação, a devota fanática reaparece e responde à pergunta que ficou no ar, ligando o medo do inferno ao fanatismo. Ela está na mesma locação de suas falas anteriores e faz a defesa da entrega total ao Frei. Ela diz, sorrindo e olhando para o lado: "Porque nossos olhos quando bota para Frei Damião, não temos força para dizer nada. A não ser se curvar e se entregar para ele fazer da gente o que quiser. Se ele disser: eu vou lhe matar agora, eu acredito que nenhum cristão se revolte, se entrega assim como nós nos entregamos a Deus Nosso Senhor". A resposta à pergunta do entrevistador, apesar de não se dar no sentido literal do texto, funciona como mais uma demonstração do fanatismo sistematicamente negado pelo Frei, que, na seqüência seguinte, dará sua própria resposta à questão.

Pressionado pelo entrevistador e assumindo uma postura mais defendida, Frei Damião explica, olhando para baixo, que "o fanatismo é..., o fanatismo é... quando o povo entende mal a religião, atribui a um padre coisas que somente Deus pode realizar". Uma vez identificado o confronto ideológico, Frei Damião opta por entrar no diálogo de forma mais séria, apresentando-se como um religioso com conhecimento sobre o assunto. Deixa de lado seu personagem sorridente, bonachão e que não entende exatamente o que o entrevistador quer dizer com fanatismo, para se apresentar como atento e consciente. Esta mudança de postura pode ser considerada um exemplo de "crise da representação", por revelar um despreparo cênico do ator natural. Em sua primeira personagem dramática, Frei Damião se apresentou de forma ingênua, buscando no entrevistador um aliado. Ao longo da entrevista, contudo, ele se dá conta de que esse personagem não foi bem sucedido e que, para enfrentar um adversário carregado de argumentos racionais e organizados, é preciso rever sua atuação, assumir uma postura mais assertiva e mostrar que tem o controle da situação. Neste sentido, a crise tem um potencial revelador, por 
desmascarar uma persona do Frei sob a qual estavam escondidos alguns detalhes fundamentais na construção de um juízo, por parte do espectador. A crise interessa obviamente à montagem, que a incorpora e continua tentando ativamente articular seu argumento.

O processo de "desmascaramento" de Frei Damião se desenvolve numa série de intercalações, entre seqüências com trechos da entrevista e cenas que retomam a situação de interação entre o religioso e a fila de fiéis, contrastando de maneira acentuada o discurso do religioso e suas ações. Nas seqüências de caráter mais observacional em que a câmera registra o contato entre o Frei e os fiéis - que aqui tem um caráter mais privado e personalizado, mas que logo adiante assumirá uma dimensão coletiva, com a interação do Frei com a multidão -, o fanatismo é pretensamente revelado. A postura do Frei em relação à massa de fiéis é a de um estímulo vaidoso à devoção. Ao mesmo tempo, o tema do diálogo que se desenvolve é a obediência, uma questão central na leitura proposta pelo documentário de que o fanatismo interessa aos dominantes.

O Frei está diante da mesma senhora que o comparou a Padre Cícero. Ela lhe diz: "Eu busco o que eu quero, que é obedecer à voz de frei Damião e peça a Deus por mim Frei Damião, tenha compaixão dessa alma pecadora, penitente, desobediente”. Dirigindo-se agora à câmera ela prossegue - enquanto Frei Damião permanece impassível - dizendo ser muito desobediente, por não seguir os conselhos que recebe dele. Neste ponto, o Frei ri e busca a câmera com o olhar. A fiel também olha em direção à equipe e arranca novas risadas do religioso quando afirma que se "ouvisse os conselhos de Frei Damião já seria uma religiosa". No momento em que se vê pego em flagrante, Frei Damião parece buscar a cumplicidade da câmera. Isto é, quando a câmera revela sua silenciosa aceitação da devoção exagerada e seu consentimento em ser colocado numa posição de guia, de líder - embora já tenha afirmado, no contexto da entrevista, que este tipo de relação é condenável.

Evidencia-se também, nessa seqüência, a sobreposição dos dois níveis de encenação nos quais o filme opera: a mise-en-scène do próprio documentário - que se explicita no diálogo com a 
câmera -, e o teatro religioso, que determina o posicionamento dos fiéis, a relação entre eles e o Frei, etc. Mais uma vez, percebe-se uma ruptura no sistema de significação, e isso permite que um novo sentido surja a partir de um elemento da cena, que foge do controle. Quando Frei Damião rompe o código da encenação religiosa - pedindo a aprovação da equipe, que trabalha no plano da encenação fílmica - ele mais uma vez se fragiliza como protagonista e confunde suas duas personas.

Voltando à entrevista e seguindo a lógica da montagem, a próxima seqüência é quase um comentário sobre o que acabamos de ver e, mais especificamente, sobre a revelação documentada. O entrevistador insiste: "Mas o comportamento do povo em vários momentos é de fanatismo...”. Frei Damião coloca a mão na testa e sorri: "Não, não é fanatismo não". A montagem reitera a criação de contrastes entre o discurso do Frei e a maneira como ele realmente age, no sentido de deslegitimar sua posição. Após este rápido retorno à entrevista, a situação da fila de fiéis é retomada, e Frei Damião conversa com a fiel sobre um feito que ela lhe atribui. Ela afirma: "e quem retirou o mal? Frei Damião com a prece que fez a nosso senhor, o pai eterno...”. O microfone aparece no canto do quadro e a senhora relaciona-se com ele, apropriando-se da encenação documentária, para tornar público seu conhecimento sobre o poder do Frei. A fiel, alheia àquilo que sua postura representa, não se sente constrangida pela situação. Ele, por sua vez, ri encabulado, enquanto ela pede que ele aceite sua fé.

Depois de mais uma revelação sobre a conivência do Frei com o beatismo que se criou em torno dele, há um novo corte para a entrevista. A série de contrastes entre discurso e ação, do ponto de vista da voz textual, atuou na comprovação de que, apesar de textualmente a Igreja rechaçar sua existência, o fanatismo existe e tem efetivamente o estímulo de seus representantes. Neste momento, a voz literal do autor faz sua provocação final, perguntando: "Isso é bom ou mal para a igreja Frei Damião?”. A pergunta revela que a voz do entrevistador não está participando de um dialogo interno à cena, mas de um diálogo maior, entre cenas, articulado pela montagem. Do ponto de vista da entrevista, a pergunta é curiosa, tendo em vista que, em sua última 
resposta, Frei Damião havia negado que o comportamento do povo fosse de fanatismo. O entrevistador desconsidera completamente a resposta do Frei e parte do pressuposto que o fanatismo é de fato uma realidade. O beato, por sua vez, fechando o bloco, responde com um sorriso amarelo que o fanatismo "não é coisa boa não".

No contato direto do filme com Frei Damião, revelam-se alternadamente diversas dinâmicas das quais o religioso é parte: santo/fiel, santo/multidão e entrevistado/entrevistador. Este último binômio pode ser recolocado de várias maneiras. A oposição entre essas duas visões de mundo poderia ser traduzida como catolicismo/marxismo; religiosidade/racionalidade; reação/revolução, e assim por diante. Enquanto a primeira metade do desenvolvimento apresenta a visão da religiosidade popular em torno da figura do Frei, no segundo bloco, a voz textual reafirma seu poder de articulação para desconstruir essa mesma visão; seja através da situação de entrevista, seja através da busca de epifanias observacionais, que revelem seu estímulo ao fanatismo. Os fiéis ainda estão presentes, mas, desta vez, como ilustrações da discussão teórica desenvolvida entre o entrevistador e o entrevistado, e como contra-exemplos do discurso ingênuo do religioso. Ainda que a voz do texto não seja explicitada por uma narração em off, ela atua claramente de maneira a conduzir uma "leitura preferencial" ${ }^{72}$ do significado do material apresentado, sem se submeter às outras vozes presentes.

\section{FECHAMENTO}

A pergunta que fica no ar, ao final do bloco do desenvolvimento é: o fanatismo é bom para a igreja? A resposta que o documentário oferece é a de que sim. E isto fica claro na primeira seqüência do último bloco que revela, a partir da observação de uma procissão em Taperoá

\footnotetext{
${ }^{72}$ Nichols sugere que, ao enfraquecer a voz do texto, em geral, filmes observacionais se abstêm de explicitar de forma nítida o ponto de vista do autor. Assim, o espectador se vê livre para significar o material que o filme apresenta. Ao mesmo tempo, através da montagem e da articulação das diversas vozes do texto, a filme sugere o que ele chama de "leitura preferencial". Odin, embora atribua muito mais importância do que Nichols ao contexto de exibição do filme para o processo de construção de significados, sugere que um filme dá ao espectador indicações de modos de leitura. Ver NICHOLS, 2005 e ODIN, 2005.
} 
comandada pelo Frei, seu poder de mobilização popular. Entre fileiras de beatos, Frei Damião, paramentado, anda sob um pano sustentado por quatro pessoas. Uma multidão acompanha a procissão e canta uma música religiosa, que se mantém na banda sonora, durante toda a seqüência. Diversos planos mostram beatas, crianças e senhoras que fazem parte dessa massa, até revelar Frei Damião dentro de uma igreja, conduzindo uma cerimônia ao lado de um outro padre. De maneira geral, a seqüência trabalha dentro de um estilo observacional que, como discutido anteriormente, aumenta a impressão de veracidade, através da suposta revelação da realidade como ela é e de recursos da narrativa clássica. Depois de explorar o corpo a corpo individual do Frei com seus fiéis, o documentário parte para o clímax, que é o retrato do potencial dominador de Frei Damião em relação à massa popular.

A situação entrevistador/entrevistado foi completamente desconstruída e, ao voltar à locação da entrevista, a câmera mostra Frei Damião dirigindo-se diretamente a ela, em tom de sermão. Ele defende a importância de receber os sacramentos e, em especial, de receber a comunhão. Diz que “a oração é para nossa alma o que a respiração é para o corpo". Frei Damião é agora, completamente desmascarado. A persona fílmica que ele havia assumido na relação com o entrevistado - primeiro ingênua, boa e sedutora, depois séria e intelectual - está definitivamente arruinada. Ele se comporta em relação à câmera, da mesma forma que em relação à massa dominada. Suas palavras começam a ser, apropriadamente, cobertas por imagens da multidão em procissão por uma rua de Taperoá. Frei Damião está paramentado como na cena anterior e é segurado nos braços por algumas pessoas, que o protegem da multidão, enquanto ele caminha. Depois, o vemos caminhando sozinho à frente da multidão, num plano levemente acelerado. Em off, ele continua defendendo que os fiéis rezem "todo o tempo, em todo o lugar e toda a circunstância" e, em especial, "na hora da tentação". O Frei volta a estar em quadro e prossegue, dizendo que o demônio é muito mais inteligente do que nós; que sozinhos sempre seremos vencidos na luta contra ele; e que só Deus pode nos salvar, nos tornando vitoriosos neste embate. Ao final de sua fala já se escuta o som da banda de pífanos da próxima seqüência. 
$\mathrm{Na}$ conclusão, o narrador abre mão do jogo de recortes de depoimentos que estava sendo realizado, optando por uma atitude mais descritiva em relação ao fenômeno e abrindo um espaço, cada vez maior, para a persona religiosa de Frei Damião. Nas imagens de procissão, é notável o nível de mobilização e sujeição da multidão. $\mathrm{O}$ caos revela-se e a montagem não favorece a localização do espectador em relação ao que vê. É difícil entender para onde as pessoas estão indo, quem são elas, e quais são os espaços pelos quais elas circulam. Ao mesmo tempo, a voz de Frei Damião exige uma dedicação constante à religião, fala de demônios assustadores contra os quais precisamos lutar, remetendo o espectador à pergunta do entrevistador: "Mas não seria o medo do inferno que faz o povo se fanatizar e seguir atrás dos padres em quem ele acredita?".

A articulação discursiva teve seu ápice no final do desenvolvimento, com a contraposição de discurso e imagem, comprovando, nesse recorte de entrevistas e imagens, que o fanatismo interessa à Igreja. O fechamento do documentário reitera, num nível mais visual e por estratégias observacionais, aquilo que o embate verbal entre entrevistador e entrevistado já colocara no segmento anterior. A montagem trabalha agora no sentido de criar uma cronologia de causalidade entre as seqüências. Depois da procissão e da celebração da missa, Frei Damião, já em seu hábito comum, prega ao ar livre, numa revelação máxima da natureza de sua relação com os fiéis.

Um plano de câmera alta revela Frei Damião entrando numa casa e sendo cercado por pessoas. Há um corte para a imagem do religioso sendo levantado e colocado em pé sobre um pequeno muro que dá para a rua, de onde ele irá fazer uma pregação. Quando o Frei - com as palmas unidas em frente ao rosto - começa o sermão, o som da Banda de Pífanos, que seguia forte desde a seqüência anterior, vai para fundo. Ele berra energicamente; retomando a atitude vista em sua primeira pregação, no desenvolvimento do filme. Faz a defesa da utilidade da religião para a sociedade: “(...) Nosso senhor nos conserve sempre nosso espírito religioso que nos anima, para 
vosso bem, para o bem de vossas famílias e para a prosperidade de pátria. Por que a religião não somente é útil para os indivíduos e para as famílias, mas também para a sociedade (...)”.

Neste trecho, surge uma proposição recorrente no olhar dos membros da Caravana sobre a religião: a aproximação entre Igreja e Estado, entre religião e poder. Como diz Frei Damião, a religião é útil para a sociedade. A pregação continua, com o áudio permanecendo sem cortes aparentes, enquanto as imagens revelam rostos emocionados de fiéis na platéia; até que, ao final do sermão, vê-se um plano da multidão batendo palmas, acompanhado de um sobe som. Este plano é repetido, mas nesta segunda inserção a imagem da multidão aplaudindo é seguida de um movimento de câmera, que revela a extensão desta platéia. O plano seguinte mostra Frei Damião já de saída, sempre cercado por centenas de pessoas, caminhando em direção à câmera. O clima é de histeria completa. As pessoas tentam encostar-se a ele, e o seguem até uma caminhonete que já estava a sua espera. O beato então entra no carro e parte, deixando a multidão para trás.

Neste ponto começa-se a ouvir um áudio baixo de uma oração coletiva. Vê-se a imagem, sem som ambiente, de uma mulher ajoelhada no chão, que cobre o rosto com as mãos, faz cara de desespero e berra. Finalmente, um plano geral da praça onde a multidão se dispersa; ponto onde termina o áudio de oração. Se a presença do Frei Damião gera uma histeria coletiva, sua ausência provoca desespero nos fiéis. A imagens denotam que relação com o beato acontece num nível de profunda dependência psíquica. O Frei é a salvação diante de todos os males da vida cotidiana, de toda a doença e de toda a pobreza.

O documentário, que se iniciou com a fanática cantando "Senhor Deus, pela vossa sagrada paixão e morte, misericórdia...”, termina também com ela, que está na mesma locação de sua primeira aparição, dizendo "senhor Deus, misericórdia...”. Agora o som da entrevista é cortado, mas a imagem da devota falando - com a mesma veemência de seus outros depoimentos - se mantém, sendo coberta pelo som da banda de pífanos e seguida pela cartela de fim. A personagem reitera, neste final, sua entrega total à religião, concretizada na devoção a Frei 
Damião. Seu depoimento continua sem som porque, de certa forma, não precisa mais ser ouvido. Trata-se da reprodução de um discurso já conhecido. Evidentemente, não é ela quem escolhe continuar falando sem áudio, mas a sensação que se cria é, mais uma vez, a de alheamento fanático. Ela pode falar sem parar; não importa se continuamos ou não ouvindo; não importa a quem se dirige este discurso.

Para sintetizar os pontos levantados ao longo deste capítulo, pode-se dizer que, em "Frei Damião", a voz textual afirma-se completamente. Paradoxalmente, esta voz afirmativa escondese na ausência da locução, que tem, neste momento histórico, o início de seu declínio. A voz em off autorizada e de cunho sociológico começa a ser rejeitada pelos cineastas brasileiros na segunda metade da década de 60, e é definitivamente condenada nos anos 70 e 80 . Em relação à "Viva Cariri!", a presença do comentário é ainda menor; muito embora a articulação discursiva realizada pela montagem seja mais atuante do que no filme de Sarno, e exista uma maior hierarquização entre a voz textual e as outras diversas vozes presentes no filme.

A narração em off aparece apenas no início, tendo um caráter irônico e informativo, retornando no desenvolvimento na forma da voz literal do autor, completamente identificada com o enunciador. Ao seu lado, temos a presença da fanática que - apesar de estar motivada a provar a santidade do Frei e de aparentemente atuar como ordenadora de significados - subordina-se ao enunciador e é utilizada pela montagem como a personagem-tipo do fanatismo. Em seguida, estão os entrevistados populares, que narram suas experiências de devoção. Com estes testemunhos, Paulo Gil antecipa um olhar sobre a "religião subjetiva", que se torna mais comum ao longo da década de 70. Por outro lado, sua filiação ao documentário de tese, ou ao dito "modelo sociológico", ainda é nítida: o filme reduz as experiências dos entrevistados populares a mero pano de fundo ilustrativo para a tese do filme.

Finalmente, temos as múltiplas vozes de Frei Damião, verdadeiro protagonista do documentário, dividindo seus esforços de atuação entre duas categorias de mise-en-scène: a 
religiosa e a fílmica. No momento do embate ideológico com o entrevistador, ele se coloca, por assim dizer, numa posição horizontal em termos de conhecimento e experiência, mostrando-se passivo e hesitante. Em contraponto, na interação com a massa de fiéis - registrada através de estratégias observacionais nas quais se radicaliza o apagamento do enunciador - sua posição é de dominação enérgica e seu poder de manipulação é revelado pela imagem. Nesta oposição entre o argumento religioso e a evidência de fanatismo, o filme pretende desmascarar Frei Damião.

Rejeitar a "voz do saber" como uma instância de enunciação ordenadora, e optar por dar voz aos entrevistados, sem comentários, tornaram-se procedimentos bastante comuns nas décadas seguintes. É importante destacar, contudo, que a ausência da narração em off não altera o fato de que não é a realidade que nos fala através do filme, mas sim a voz do texto. Da mesma maneira, o fato da tese do documentário estar mascarada atrás da pergunta - "mas quem é Frei Damião?" - apresentada no segmento de abertura, também não altera o fato de que há a construção de uma "resposta", e que esta é de responsabilidade e se identifica ideologicamente com o autor. A maior evidência disto é que, apesar de todas as vozes do filme endossarem a santificação de Frei Damião, o documentário conclui que ele é atualização do fanatismo - nocivo à população e interessante à Igreja e ao Estado - que envolve a beatice.

A construção desta resposta é engenhosa e parte de um aparente apoio do documentário à suposição de que Frei Damião seja um santo; tanto na apresentação do documentário, quanto na primeira parte do desenvolvimento. Até este momento, os fiéis entrevistados apóiam esta tese, apesar de serem intencionalmente observados com distanciamento e desconfiança pelo enunciador. Em seguida, na acareação com o Frei, esta imagem começa a ser desconstruída. Para tanto, não é necessária a presença de um locutor que afirme diretamente suas posições, já que o recorte de falas e sua articulação criam uma falsa sensação de que o discurso se auto-organiza. 
Assim, o espectador é levado a concluir - ainda que esta não seja uma leitura obrigatória - que o fanatismo é favorável à igreja, e que esta o estimula através do medo do inferno e da punição. Percebemos que a figura do beato cria um apoio ilusório para o que há de mais prosaico e carente na vida destes fiéis: o rádio quebrado, a aliança perdida, as verrugas eliminadas. A Igreja e o Estado sabem disso e são coniventes no objetivo de controlar e mobilizar as massas. Em "Frei Damião", um "locutor invisível" - que nada mais é do que a "voz textual" - organiza os materiais apresentados e os vários olhares em relação ao tema, para refletir seu próprio olhar, que talvez seja também o nosso. 


\section{CAPÍTULO 4 | "DE RAÍZES E REZAS, ENTRE OUTROS": UM CALEIDOSCÓPIO SERTANEJO}

Nos capítulos anteriores foram analisados dois documentários que, de diferentes maneiras, retrabalham questões ligadas a um certo documentário expositivo, de caráter sociológico, comum na primeira metade da década de 60. Tanto "Viva Cariri!", quanto "Frei Damião" apontam para alguns procedimentos que vão se colocar de forma mais nítida no documentário brasileiro da década seguinte.

"De Raízes e Rezas, entre outros" (cor, 38 minutos, 16mm, 1972), o terceiro filme a ser discutido por esse trabalho, acentua algumas das tendências de transição esboçadas nos dois primeiros documentários, num movimento que tem, em primeiro lugar, um componente histórico. Filme de montagem, "De Raízes e Rezas” é uma compilação, realizada em 1972 por Sérgio Muniz, de materiais captados três anos antes, durante a Caravana Farkas e pretende estabelecer um painel sobre o sertão, com um certo distanciamento do momento político e histórico da captação.

Logo após as filmagens da Caravana, Sérgio Muniz já havia editado três outros documentários, mas sua participação no projeto não se resume a estes trabalhos. Além de dirigir, Muniz esteve presente desde a fase de pesquisa para a série, atuando como produtor na maior parte dos 19 filmes de "A Condição Brasileira". Os documentários dirigidos por Muniz têm em comum o fato de enfocarem personagens particulares da cultura nordestina; quase sempre ligados a atividades arcaicas, em vias de desaparecimento. Em “A Erva Bruxa” (1969-70), por exemplo, a decadência tem uma conotação sócio-econômica. O curta-metragem apresenta um panorama da cultura do tabaco e da produção de charutos no Recôncavo Baiano, em franco declínio. Já em “Rastejador, s.m.” (1970), o declínio está ligado a um passado mais remoto da história do sertão: o cangaço. João Batista, personagem principal era, segundo a narração do filme, um "auxiliar das volantes num passado mistificado", ou seja, aquele que seguia, no meio da caatinga, os rastros de um cangaceiro, graças a um conhecimento muito profundo do ambiente local. 
Muniz conhecera João Batista em 1967, em Santa Brígida, e o retrata novamente em "Beste" (1970), um filme sobre uma espécie de arco e flecha medieval ainda utilizado para caça na região. Mais uma vez, o tema é a permanência cultural. Batista era um dos poucos homens da região que ainda sabia construir o instrumento. Acentuando o contraste entre o arcaico e o moderno, Muniz sonoriza o filme com a narração da transmissão de rádio da chegada do homem à lua (o homem pisou na lua na semana que Muniz filmava em Santa Brígida), sobre as imagens da construção da beste.

Em "De Raízes e Rezas, entre outros" a permanência ou a sobrevivência de aspectos arcaicos da cultura nordestina são retomadas. O filme, que é uma co-produção entre Thomaz Farkas, Cinema de Cordel $^{73}$ e Cinemateca do Museu de Arte Moderna do Rio de Janeiro, tem origem quando Farkas chama Sérgio Muniz para revisar as sobras do material captado em 1969. Muniz encontra, em meio a este material, registros de dois personagens que não haviam sido usados nos outros filmes da série. O primeiro era uma rezadeira de mais de cem anos, do interior da Bahia; e o segundo um raizeiro do Ceará, que também detinha um saber popular em vias de desaparecimento.

A rezadeira havia sido descoberta na Bahia pelo próprio Muniz, durante a viagem de preparação da Caravana. Ele decidiu que quando voltasse ao Nordeste iria filmá-la, apesar de não saber o que faria com aquele material. O raizeiro também foi encontrado por ele, durante as filmagens de Geraldo Sarno no Ceará: "um dia eu saí com o Farkas e descobrimos um raizeiro na feira, o cara vendia raiz. Vamos documentar o trabalho dele na feira e na casa dele, onde ele fazia

\footnotetext{
${ }^{73}$ O primeiro curta-metragem de Sério Muniz é "Roda", de 1965; também produzido por Thomaz Farkas. Caetano, Gil e Capinam, amigos de Geraldo Sarno, vêm para São Paulo no início de 1965 para escrever a letra e a canção tema de "Viramundo" (1965). Sérgio Muniz ouve Gil cantando algumas canções e pede autorização para fazer um filme a partir delas. Ele grava então cinco canções e reúne, com o apoio de amigos, material de arquivo: gravuras e desenhos de cordel, sobras de "Vidas Secas", material filmado por Paulo Gil na pré-produção de "Deus e o Diabo", entre outras coisas. A partir desta experiência, Sérgio Muniz funda uma empresa chamada Cinema de Cordel. Sua idéia era produzir um cinema análogo a este tipo de literatura: popular, anônimo e que pudesse ser consumido como um livro de cordel.
} 
operação em boca de cavalo, tratava uma infecção, enfim, era um raizeiro meio curandeiro, também documentei e disse: 'não sei o que vai acontecer, estava lá guardado, arquive"'. ${ }^{74}$

Os dois personagens são o núcleo central do filme, ao redor dos quais Sérgio Muniz constrói uma iconografia do sertão, re-aproveitando materiais filmados na Bahia, no Ceará, em Pernambuco e na Paraíba. Situações presentes em diversos outros filmes da série estão ali: imaginários, procissões, migrantes, as feiras, os pequenos produtores, os artesões, os beatos, etc. Estruturalmente, os dois personagens principais não têm importância maior do que outros temas, até porque o documentário é - antes que biográfico - um painel que busca articular um discurso genérico sobre o sertão. Por outro lado, as seqüências que retratam estes dois personagens se destacam das demais, por receberem um tratamento diferenciado em termos de estilo. A ausência de música e os planos longos, por exemplo, são encontrados apenas nestes dois momentos.

Para evitar problemas com a censura, Muniz preferiu não utilizar a narração off, substituindo-a por fragmentos de canções brasileiras ou latino-americanas. ${ }^{75}$ Apesar da intenção declarada do autor ter sido política, o uso da música como comentário é uma das características do filme que melhor sinalizam o afastamento do dito documentário de tese. Assim, o comentário, que já havia sido questionado por "Viva Cariri!" e "Frei Damião", é agora definitivamente suprimido. Com exceção das seqüências relacionadas ao raizeiro e a rezadeira, nas quais os depoimentos são destacados e não há música de fundo, o documentário é construído a partir de relações que se criam entre imagens dos mais variados aspectos da cultura nordestina e as letras das músicas usadas como trilha.

\footnotetext{
${ }^{74}$ Depoimento de Sérgio Muniz ao site Mnemocine.

${ }^{75}$ No entanto, isso não foi o suficiente para livrar o filme de cortes. Muniz conta: "Estava filmando no interior da Bahia um enterro de uma criancinha, um bebê, que é levado por um grupo de crianças para o cemitério e atrás tem uma zabumba tocando. Quando entrou no cemitério e a criança começou a ser enterrada, a zabumba começou a tocar o hino nacional e deixei. A censura mandou tirar e disse: 'não pode tocar o hino nacional, no enterro de uma criança' e peguei uma cópia, cortamos e mandamos para a censura e mantive uma versão integral com a zabumba tocando o hino nacional" (site Mnemocine)
} 
Isto significa que, apesar da voz do texto ser afirmada fortemente durante todo o filme, através de uma montagem rápida e descontinua, ela não trabalha na construção de uma tese unívoca, mas sim na sugestão e na articulação de vários argumentos. De um lado, surge com força a referência tropicalista, que traz consigo a ironia, o humor e o procedimento de colagem, recorrentes no plano visual e também plano sonoro. Na voz de Gilberto Gil, surge a frase que fecha o filme e que reflete o momento político pós 68: o sonho acabou. No outro extremo ainda está o horizonte da revolução, para qual a recuperação da tradição de violência que marca a historia do sertão - seja no cangaço, seja no messianismo - é fundamental. Além de canções cubanas de cunho político e alguns exemplares da canção de protesto brasileira, estão presentes no filme várias referências à teleologia profética de "Deus e o Diabo na Terra do Sol” ${ }^{76}$, através de diálogos e canções tiradas do filme. Ao lado das músicas e de alguns textos poéticos de autoria do próprio diretor, o filme utiliza ainda trechos lidos por Othon Bastos de "Morte e Vida Severina", de João Cabral de Melo Neto, onde a morte se inscreve no corpo da cultura sertaneja. No caleidoscópio, ao mesmo tempo debochado e esperançoso de Muniz, o tempo presente é apresentado com pessimismo. A revolução pode estar no futuro e o arcaico sertanejo pode ser revisto com a ironia tropicalista; mas no aqui e agora do filme o retrato é de decadência, descontinuidade e miséria.

$\mathrm{O}$ aspecto de mosaico da montagem faz com que o filme não se enquadre definitivamente nem numa estrutura narrativa, nem numa estrutura argumentativa. "De Raízes e Rezas" traz em si três grandes movimentos, que podem ser entendidos como abertura, desenvolvimento e conclusão, sem que isso signifique que ele se construa de maneira linear e continua. De qualquer forma, é possível segmentar o filme em trinta e duas seqüências, ou pequenos núcleos de sentido criados entre sons e imagem, que formalmente tem grandes diferenças entre si.

O que será considerado como abertura é um primeiro conjunto de três seqüências em que os diversos temas trabalhados no documentário são apresentados e questões fundamentais de estilo

\footnotetext{
76 "Deus e o Diabo na Terra do Sol”, direção de Glauber Rocha, 1963/1964.
} 
são estabelecidas. Em relação à escolha de imagens, são apresentados planos de quase todos os temas desenvolvidos ao longo do documentário: a rezadeira, o raizeiro, a morte, a feira, o folclore, a pobreza, os vaqueiros e a produção de tecido. O último plano é de uma espécie de praia que se cria no meio de um rio que está muito baixo. Na banda sonora o mesmo acontece; e todos os recursos utilizados ao longo do documentário estão indicados de alguma maneira: uma canção cubana, um trecho de "Triste Bahia" de Caetano Veloso e uma ladainha popular. Nesta seqüência, assim como ao longo do filme, a edição é marcada pela música, que determina o ritmo do documentário.

A partir deste ponto, os diversos temas mencionados são desenvolvidos de maneira alternada, criando ciclos autônomos em que se pode identificar também um começo, um meio e um fim. Cada um dos temas levanta algumas questões, exploradas de forma autônoma, ainda que a montagem sugira um certo encadeamento de idéias. A conclusão do filme é marcada, não pelo fechamento de um argumento, mas por uma ruptura em relação aos temas até então trabalhados e ao ritmo de montagem. A religiosidade surge com mais força e o filme se encerra num movimento referencial a seu início - em que um rio seco é mostrado -, agora na forma de um rio cheio e cercado por um vale verde.

Para entender melhor a multiplicidade de referências e de argumentos com os quais o filme trabalha, é necessário olhar separadamente para cada uma das vozes atuantes, para as referências às quais estas vozes remetem e para a construção de uma hierarquização de vozes a partir da voz do texto. No momento em que a tese, sustentada até "Frei Damião", é definitivamente pulverizada - num um olhar em relação à realidade que apesar de sugerir interpretações conforma-se melhor com a idéia de que não há uma representação única e objetiva das "coisas como ela são" -, como se coloca então a voz do texto? 


\section{VOZ DO TEXTO}

"De raízes e rezas" não trabalha com a narração em off, característica de grande parte dos documentários da "Condição Brasileira". Apesar disso, a voz do texto se ouve com nitidez. Ela é construída através de uma grande variedade de recursos: cartelas, textos poéticos e músicas - que têm explicitamente a função de comentário - e uma montagem afirmativa, que recorta e cola com rapidez imagens e sons, propondo um diálogo entre o material do próprio filme e referências externas, tais como "Morte e Vida Severina" e "Deus e o Diabo na Terra do Sol".

Nesta manipulação explícita de referências, a voz do texto parece andar em duas direções. De um lado, um registro em que múltiplas relações podem ser estabelecidas. Trabalho, religiosidade, folclore e violência, entre outros temas, são colocados lado a lado, desenvolvendo argumentos autônomos e afastando o filme definitivamente da categoria do filme de tese. De outro lado, a vocação crítica e propositiva do dito documentário sociológico não foi de todo abandonada. Entre diversas leituras possíveis dos núcleos autônomos que o documentário articula, algumas são reiteradas pela repetição, como por exemplo, a sugestão de que a violência é o único motor possível de mudança.

Alguns dos princípios básicos de estilo e abordagem estão expressos nas cartelas que abrem o filme e que podem ser reportadas imediatamente ao narrador. O documentário se inicia com uma seqüência de cartelas simples, com letras brancas (do tipo de máquina escrever) sobre um fundo preto; e com uma música em castelhano que retornará outras vezes. A primeira cartela diz: "Este filme vai prá Amazonas, Gilberto Gil, Caetano Veloso, Silvio Rodriguez e Pablo Milanés". A segunda: "Este filme utiliza realidade como se fosse ficção", e a terceira: "Qualquer semelhança dos textos ou frases musicais que usamos com os filmes, musicais ou canções das quais foram retiradas é mera coincidência". 
É interessante que a questão da utilização da realidade como ficção seja colocada de saída, uma vez que o tratamento dado ao material fílmico é realmente no sentido de desnaturalizá-lo ao máximo e de manipulá-lo de forma deliberada. Todos os recursos visuais e sonoros parecem estar servindo, de maneira clara, ao propósito de uma narração que se assume como tal. Não se trata de revelar as coisas como elas são, mas de revelar a visão do autor sobre estas mesmas coisas. Se no cinema observacional os procedimentos da narrativa clássica são utilizados no sentido de apagar o enunciador, neste caso a idéia é oposta.

Odin define o modo ficcionalizante, de maneira resumida, como aquele em que se vê um filme vibrando ao ritmo dos acontecimentos fictícios narrados, em oposição ao modo documentarizante, definido como o de ver um filme para obter informações sobre a realidade das coisas do mundo. ${ }^{77}$ Não pretendo afirmar que a relação afetiva básica do espectador com "De Raízes e Rezas" seja ficcionalizante, mas sim apontar os recursos usados por Muniz no sentido de sugerir emoções, através da dramatização de situações, e deste modo levar o espectador a estabelecer uma relação de vibração emocional com o que vê. Isto se dá principalmente pela combinação de imagens captadas por meio de estratégias observacionais de alto potencial ficcionalizante - que registram um acúmulo de cenas cotidianas da vida nordestina - e do uso da música, que, sem nenhum pudor, cria climas a partir de imagens incapazes de despertar, sozinhas, as mesmas emoções. Drama, suspense e tensão são extraídos das imagens pela montagem através da banda sonora.

Um exemplo claro disso é a longa seqüência, que antecede a entrevista do raizeiro. Nela vemos Sebastião em ação, tratando de um cavalo e sangrando-lhe a gengiva; enquanto o animal, que está amarrado, tenta resistir. Se contasse com uma narração em off expositiva, a cena seria simplesmente a ilustração de um texto sobre Sebastião; oferecendo um exemplo de tratamento feito por ele. No entanto Muniz sobrepõe a estas imagens falas de Sebastião a voz de Caetano

\footnotetext{
${ }^{77}$ ODIN, 2006, pg 33-37.
} 
Veloso cantando uma versão de "Asa Branca" ${ }^{78}$ A música, muito triste, é o olhar melancólico de um sertanejo que abandonou o sertão por causa da seca e tem a expectativa de voltar. O eu lírico fala sobre seus animais que morreram de sede: "Que braseiro, que fornaial Nem um pé de prantação/ Por farta d'água perdi meu gado/Morreu de sede meu alazão" (sic). A relação que se estabelece a partir desta superposição, transforma a cena do tratamento do cavalo em uma situação épica - o sertanejo tem que sacrificar seu burro para salvá-lo da adversidade - que amplifica, aos olhos do espectador, o sofrimento do animal.

Finalmente, usar a realidade como ficção é, de certa forma, questionar os limites da representação fílmica do real. É assumir que a revelação objetiva da realidade é impossível, e que o documentário e a ficção são formas de representação mediadas por um enunciador; e não transposições objetivas dos fatos. Quando o narrador, num procedimento similar ao que se observa em momentos de "Viva Cariri!", incorpora à banda sonora uma série de falas em off curtas não identificadas, sua intenção não é criar a sensação de procedência real, ou qualificar o relato como a captura de uma realidade objetiva. Se fosse este o intuito, seriam necessárias a indicação de origem e a aproximação entre o que é dito e quem o diz. No momento em que o diretor opta por gerar dúvidas sobre quem está enunciando, ele dispõe da realidade e incorpora claramente este enunciado à própria instância da narração. Da mesma forma, a predominância de imagens sem som ambiente revela um descolamento da idéia de aumentar a fidelidade da representação; acentuando o aspecto da manipulação explícita e gerando uma sensação de estranhamento.

A última cartela da abertura - "Qualquer semelhança dos textos ou frases musicais que usamos com os filmes, musicais ou canções das quais foram retiradas é mera coincidência" - reivindica uma autonomia da representação fílmica face aos elementos reais que a originam. Assim como um filme ficcional se protege de uma possível cobrança de verossimilhança ao colocar que

\footnotetext{
78 "Asa Branca" é uma canção de Luiz Gonzaga, de 1947, re-gravada por Caetano Veloso no disco Caetano Veloso, lançado em 1970 na Inglaterra e 1971 no Brasil.
} 
"qualquer semelhança com fatos reais é mera coincidência", também aqui o autor solicita uma liberdade do texto em relação a suas fontes. Na proposta, há um quê de ironia, uma vez que a identificação entre a voz do texto e as vozes que ela articula existe e é intencional, ainda que os significados que surgem através de sua recontextualização possam ser inesperados. Não acredito, no entanto, que o deboche se deva unicamente a preocupações com a realização fílmica. Muniz manifesta claramente o cuidado de se proteger da censura, propondo uma total autonomia do filme em relação à realidade, ao mesmo tempo em que o inscreve no momento histórico e procura discutir esse momento.

Da mesma forma, o uso de músicas no lugar do comentário traz em si essas duas informações: uma opção de estilo e uma necessidade política. Muniz justifica sua opção pelas canções, com uma questão de contexto de produção: isso protegeria o filme de uma chave de leitura óbvia que poderia incomodar a censura. Por outro lado, inevitavelmente, do ponto de vista formal, a escolha insere o filme numa discussão sobre o modo de fazer documentário.

Em primeiro lugar, é preciso destacar que o filme é dedicado aos quatro compositores que dominam a maior parte de trilha sonora, conforme colocado na primeira cartela: Gilberto Gil, Caetano Veloso, Silvio Rodriguez e Pablo Milanés. A dedicatória é inteiramente justificada, porque o texto, empresta desses autores diversos elementos fundamentais para sua construção. Além da sonoridade, das letras tornadas significativas na montagem e do fato de determinarem inteiramente o ritmo do filme, as músicas agregam ao texto também suas informações de origem. Não é apenas a música tropicalista que está presente, mas também um estilo, uma visão de mundo, com os quais o filme dialoga intensamente. Não é apenas a voz de Silvio Rodriguez que se ouve, mas também suas determinações históricas e sociais, que ainda trazem em si o horizonte da revolução.

O documentário trabalha basicamente com três tipos de linguagem musical. A música cubana aparece na voz de Pablo Milanés e Sílvio Rodriguez. As letras, de caráter mais dramático, trazem 
em alguns momentos um convite à conscientização política. A mesma vocação de mobilização política está representada por Edu Lobo e Milton Nascimento. No pólo oposto, o tropicalismo surge nas vozes de Caetano, Gil e Gal, que cantam músicas dos discos Tropicália (1968) e Transa (1971), e oferecem uma releitura da canção popular nordestina através da versão de Caetano para "Asa Branca". O tropicalismo deixa, além disso, sua marca em aspectos do estilo do filme: a colagem, a descontinuidade narrativa, e a ironia são características deste movimento musical que parecem ter influenciado Muniz. Ao lado da canção popular contemporânea ao filme, são incorporados a ele - assim como em absolutamente todos os documentários da Caravana extratos sonoros da religiosidade nordestina; através de orações, ladainhas e de manifestações musicais tradicionais, como as bandas de pífanos.

Estas categorias, no entanto, não são utilizadas de forma estanque e são constantemente interrelacionadas pela montagem. A predominância é de músicas com letras, que não apenas comentam, mas criam uma interdependência em relação às imagens. Existem, por exemplo, cortes bruscos entre músicas, que podem mudar mais de uma vez numa mesma seqüência; ou o uso de uma única frase musical de uma canção, sendo imediatamente seguida por outra frase, de outra canção. Nessa colagem de trechos, surgem novos significados, que devem ser atribuídos ao narrador.

A idéia é que a música comente a imagem e isso não é disfarçado, pelo contrário: se uma imagem pede um comentário, a música entra imediatamente, respondendo a esta solicitação.

Em alguns momentos, o comentário musical é bastante óbvio, como, por exemplo, no início de uma seqüência que aborda a questão da migração. Sobre imagens de um grupo de pessoas reunidas em uma rua estreita - onde se vêem um caminhão ao fundo e, em seguida, closes de homens e mulheres do grupo - ouve-se o som instrumental da banda de pífanos. Há um corte para a imagem de um homem experimentando um par de óculos numa feira nordestina. A 
banda sonora acompanha então o corte, inserindo uma única frase musical na voz de Caetano, que comenta o significado literal da imagem: "tá na cara, eu...". ${ }^{79}$

Em seguida o plano de um caminhão, com migrantes na caçamba, que se movimenta em direção à câmera; enquanto do lado de fora muitas mulheres de chapéu atravessam uma ponte a pé, sob o áudio de uma ladainha religiosa em BG. Outras imagens de migrantes se seguem: caminhões parados com trabalhadores dentro, caminhões andando, closes de migrantes. Comentando-as, entra a voz de Caetano: "It's a long road, it's a long road, it's a long and winding road..." ${ }^{80}$, numa referência bem explícita à longa e tortuosa estrada que aguarda estes "paus de arara" no caminho para o sudeste, garantindo ao mesmo tempo o espectador que as imagens se referem mesmo à migração. Eliminando definitivamente qualquer dúvida sobre a visão pessimista do narrador em relação ao fenômeno, entra a voz de Othon Bastos lendo um texto que se supõe ser do próprio autor: “Ó Maria, ó migração; a miséria de caminhão”.

O tema se alonga ainda por duas seqüências, constituindo um núcleo temático de relativa autonomia, em que a voz do texto parece indicar que a migração é a simples transferência geográfica da miséria. Na cena seguinte, a câmera se aproxima do caminhão parado da seqüência anterior, revelando suas malas e reiterando a condição de viajantes, enquanto uma voz de nordestino não identificada fala em entonação de repente: "mas não dá para eu pagar o pato (sic) do caminhão". Duas seqüências adiante, o caminhão de migrantes parte por uma rua movimentada e a voz de Caetano comenta, em mais uma superposição óbvia: "ê galo cantou, ê galo cantou camará, ê cocorocó, ê cocorocó camará, ê vamo-nos embora, ê vamo-nos embora, ê vamo-nos embora camará, ê pelo mundo afora, ê pelo mundo afora, camará" ${ }^{11}$

\footnotetext{
79 Trecho de "Mora na Filosofia" (Monsueto Menezes - Arnaldo Passos), gravada por Caetano Veloso no disco Transa. O disco foi lançado na Inglaterra em 1971 e no Brasil em 1972.

${ }^{80}$ Trecho de "It's a Long Way" (Caetano Veloso), gravada por Caetano também em Transa. O verso em questão é uma referência a canção "Long and Winding Road", dos Beatles, lançada no álbum Let it Be, de 1970.

${ }^{81}$ Trecho de "Triste Bahia” composta por Caetano a partir de um soneto de Gregório de Mattos e que integra também o disco Transa.
} 
Neste trecho da música "Triste Bahia" Caetano faz uso de uma tradicional ladainha de capoeira. Vale comentar aqui que, embora este procedimento tenha semelhança com a incorporação da tradição popular que vemos em diversos outros filmes da Caravana, da perspectiva tropicalista, tal re-processamento da matéria bruta popular guarda diferenças sensíveis com uma postura de preservação ingênua. Diferencia-se também da tentativa de criar uma arte popular que funcione como porta de comunicação entre a arte não alienada e o povo alienado; muito comum nas discussões da década de 60 sobre a produção cultural. A conjugação constante que o tropicalismo propõe entre moderno e arcaico, cultura popular e cultura de massa, diz respeito a redescobrir e criticar a tradição a partir de uma nova sensibilidade, assumindo as contradições da modernização do país. O filme, por sua vez, dialoga com a proposta tropicalista, aceitando e destacando as contradições da região.

Isso fica bastante claro no uso que a narração faz de um trecho da música "Geléia Geral". Enquanto uma câmera fixa observa a chegada de três vaqueiros tocando bezerrinhos, que surgem na curva de uma estrada de terra, Gil canta: "Ê bumba-iê-iê-boi/ ano que vem mês que foi/ ê bumba-iê-iê-iê/ é a mesma dança meu boi”. Há um corte para uma cena sem som ambiente de uma manifestação tradicional - chamada de maneiro-pau - na qual dois homens fantasiados, cercados por uma roda, encenam uma luta de espadas. Sobre esta, entra a voz de Othon Bastos: "Estão querendo calar até meu boi mandingueiro, mas ele, vivo, matreiro, me fez um refrão para cantar”. Voltamos para os três vaqueiros, ao som da música de Gil. Os vaqueiros seguem pela estrada lentamente, tocando os bezerros e passando pela câmera que segue imóvel.

Aqui, múltiplas referências estão sendo trabalhadas. De um lado, o bumba-iê-iê-iê é a alegoria do Brasil, no sentido de traduzir figurativamente a contradição entre arcaico e moderno inerente ao país. ${ }^{82} \mathrm{O}$ discurso sobre o Brasil dialoga com a imagem do vaqueiro, que é a personificação da

\footnotetext{
${ }^{82}$ A música faz parte do disco Tropicália. Trata-se de uma colcha de retalhos de clichês ufanistas e uma justaposição de moderno e arcaico, desmascarando com ironia a confusão cultura-natureza e apontando para as disparidades da "geléia geral” brasileira. Para uma análise aprofundada ver FAVARETTO, 2000. p 107 a 111.
} 
permanência da cultura do gado, do sertanejo resignado com seu destino, sobrepondo a ele um componente lúdico e carnavalesco, e criando assim um contraste. Em seguida, a encenação da luta folclórica é acompanhada por uma reivindicação - de responsabilidade do narrador - de alegria e potência. O boi mandingueiro é aquele difícil de ser capturado e que, portanto, não é facilmente dominado. Ele é a antítese do oprimido e responde à tentativa de lhe calarem com a música e a alegria. A cultura popular é reabilitada e, momentaneamente, distanciada da posição condenável de arte alienada, para ressurgir como mecanismo de resistência. "A alegria é a prova dos nove", conforme a citação que a própria música faz de Oswald Andrade, e pode ser um modo crítico de prazer.

Algumas seqüências adiante, o boi mandingueiro retorna, desta vez no plano visual. Uma imagem sem som ambiente de dois vaqueiros a cavalo, tentando domar um boi em meio a um campo verde, é coberta por uma música instrumental dramática e grandiosa, que cria um clima de suspense e emoção. Segue-se uma série de faux raccords de planos curtos que mostram os vaqueiros cercando o boi. A combinação da potência sonora com a descontinuidade das imagens produz um registro épico. O espectador tem à sua frente não mais uma atividade cotidiana e massacrante, mas uma grande batalha entre o boi e o vaqueiro. A música segue num crescendo até atingir seu máximo de tensão. Há então um corte na imagem para uma cena em que dois homens colocam peles de boi para secar numa estrutura de madeira. O modo de produzir sentido, aqui, pode ser o ficcionalizante, quando deduzimos que o couro estendido é o boi mandingueiro vencido.

A cronologia causal continua na cena seguinte, em que o couro do boi derrotado passa a ser costurado por um artesão. O artesão está de perfil, trabalhando sobre uma mesa numa sucessão de planos: ele corta o couro, costura; detalhe da máquina de costura; detalhe de mão costurando. O plano seguinte nos leva de volta aos vaqueiros, agora sem o boi mandingueiro. Bethânia canta 
“é borandá que a terra já secou, borandá/ é borandá que a chuva não chegou..." ${ }^{\text {, }}$, enquanto a câmera se movimenta mostrando detalhes dos vaqueiros: o pé no estribo, os rostos, as roupas de couro. O boi mandingueiro vencido foi transformado nas roupas de vaqueiro, fechando a cronologia. Há então um corte para dois vaqueiros cavalgando em campo verde, no sentido oposto à câmera, até se distanciarem.

Se, na primeira seqüência, o sofrimento do vaqueiro é redimido pela carnavalização e pela alegria tropicalista, neste segundo núcleo o didatismo da canção de protesto e a energia imposta pela montagem são os elementos que inserem drama no retrato do vaqueiro, que passa da condição de oprimido para a de herói ficcional. O narrador passeia por estes dois pólos, sem se definir por um deles; circulando por entre diversas referências contemporâneas ao filme. Neste composto de dois movimentos opostos, a voz do texto injeta nos personagens potência e vitalidade, tirando-os - à sua própria revelia - de uma posição resignada. Os gestos dos vaqueiros são rápidos, fortes e vencem o boi, que por sua vez os libertam na canção.

\section{ENTREVISTAS}

A voz do autor, que está implicitamente presente através dos recursos vistos acima, torna-se literal durante as duas únicas entrevistas do documentário: a do raizeiro Sebastião e a da rezadeira Maria. Como já comentado acima, os dois depoimentos não são organizadores da narração, nem são os fios condutores do discurso. Eles poderiam ser vistos como o núcleo central do filme, ao redor do qual é disposta uma iconografia nordestina. O tema da permanência, constante no trabalho de Muniz na Caravana e que percorre todo o filme, é nessas duas situações desenvolvido com mais verticalidade. Ao mesmo tempo, a dimensão ensaística

\footnotetext{
${ }^{83}$ Trecho de "Borandá", canção de Edu Lobo, interpretada por Bethânia no disco Edu e Bethânia, de 1967. O disco, de forte cunho político social, se filia ao movimento da canção de protesto e a música fala sobre a miséria do sertanejo nordestino que, tendo a oração com único recurso, se vê obrigado a mudar.
} 
que se observa em boa parte do documentário é aqui substituída pelo registro e pelo princípio de preservação de manifestações em vias de desaparecimento. ${ }^{84}$

Nas entrevistas, a voz literal do autor está presente. Nelas observa-se uma horizontalidade na relação entrevistador/entrevistado maior do que nas entrevistas com personagens populares dos outros dois documentários. Os personagens, em "De Raízes e Rezas”, dizem seus nomes, num procedimento raríssimo entre os filmes da Caravana, nos quais, via de regra, os entrevistados populares não são identificados, já que suas experiências são típicas. Aqui, há a personalização da experiência do entrevistado, o que por si só contribui para uma maior atribuição de valor à sua subjetividade. Suas experiências são ouvidas, consideradas e respeitadas pelo autor no momento do diálogo, bem como apoiadas pela montagem. O ranço paternalista do intelectual em relação aos oprimidos ainda se faz presente, mas, de alguma forma, percebe-se uma admiração genuína do autor pelos dois personagens, vistos como dois focos ameaçados de resistência cultural.

O diálogo com populares - que é muito diretivo no caso de "Viva Cariri!", e inexistente em “Frei Damião", devido à omissão do autor - ganha aqui contornos mais livres. A conversa não tem a finalidade de extrair conteúdos pré-determinados do entrevistado para confirmar uma tese. No momento da filmagem, revela-se o caráter aleatório daquele registro. Isto é, a entrevista não tinha um objetivo para além da documentação daquelas experiências, segundo o relato de Muniz. A liberdade da filmagem ganha espaço na montagem, uma vez que o filme não articula

\footnotetext{
${ }^{84}$ Ao comentar o filme "Congo" (1972; direção de Artur Omar), que tematiza a congada sem apresentar uma única imagem da festa, Bernardet afirma que o filme se diferencia da maior parte da produção da época: "Filme de sonegação ("filme em branco") em oposição aos outros que oferecem abundantes imagens destas festas populares em vias de desaparecimento. Em ruptura com essas imagens. A ruptura (...) consiste na afirmação radical da impossibilidade de representar, de reproduzir na tela o fenômeno "congada" ou uma congada em particular. Problema esse que outros filmes da época não tematizam, fornecendo ao espectador uma última olhadela ingênua sobre esses espetáculos antes que a cortina se feche definitivamente.” (BERNARDET, 1980, p.07). Do ponto de vista desta afirmação de Bernardet, Muniz opta, nessas entrevistas, pela olhadela ingênua, já que tem a ilusão de revelar "verdadeiramente" estas formas de saber popular em extinção e de protegê-las do desaparecimento. Apesar disso, em diversos outros pontos do filme, um questionamento sobre a representação fílmica esta presente. Essa tensão entre o registro e a discussão sobre os limites deste registro aparece também de forma incipiente em "Viva Cariri!”, embora no caso do filme de Sarno a dimensão descritiva prevaleça.
} 
uma tese. As entrevistas são nucleares, ao levantarem questões de forma autônoma; principalmente sobre o conflito entre modernização e preservação. Estas questões por sua vez são irradiadas e penetram em outros núcleos temáticos, nos quais serão circularmente desenvolvidas.

A entrevista de Sebastião surge um pouco antes dos 15 minutos do filme. No entanto, uma leitura que poderíamos denominar de retroativa do documentário revela alguns indícios de sua presença, anteriores a esta entrada. Logo após as seqüências de abertura, por exemplo, um plano geral de uma cidadezinha nordestina é seguido por um travelling sobre bonequinhos de Padre Cícero e de outras personalidades dispostos numa calçada. E, sobre as imagens, ouve-se em off a voz de Sebastião, que até o momento o espectador não sabe quem é: "Porque às vezes a gente não quer dizer as coisas. Então o povo insiste e é o jeito". Neste ponto do documentário, a fala de Sebastião é puramente indicial. Ao mesmo tempo, assim como outras falas curtas em off sem identificação, ela também acaba servindo à narração de maneira bem humorada. É como se o próprio narrador anunciasse que vai dizer coisas que não gostaria, mas que o faz por insistência do povo.

Outras duas falas do raizeiro antecedem ainda sua primeira aparição. A seqüência nove começa com a cena de uma banda de pífanos tocando numa praça, com som ambiente. Em seguida, vêse um plano de vários cavalos parados, numa praça de terra, e, no fundo, um caminhão. A música dos pífanos continua em BG, enquanto surge sobre a imagem a voz em off do raizeiro, dizendo: "Eu trato, mas está devagar agora, está aparecendo pouco, o comércio está ruim, está fraco. Os que têm animal não pode nem tratar (sic)". O filme retorna para a banda tocando na praça, com som direto, e corta, em seguida, para uma imagem de muitas pessoas aglomeradas de costas, ao redor de alguém que fala. Sobre a imagem, uma voz em off, que poderia ser atribuída a essa pessoa em torno da qual a multidão está, anuncia: "Porque diz a medicina moderna que $70 \%$ da nossa população brasileira é atacada de verme porque vive em terra funda, toma água sem ser coada, sem ser filtrada, apanha no chiqueiro de porco, numa privada sanitária e apanha 
estas parasitas estas paranta (sic) e que vem atacando e que mata sem doer $70 \%$ da população brasileira...”.

A fala de Sebastião, nessa segunda vez, dá ao espectador um pouco mais de elementos sobre sua origem, informando que seu trabalho relaciona-se com o tratar de animais e que o mercado está difícil. Como contraponto, segue-se a imagem da feira com um áudio que, da perspectiva da "medicina moderna", apresenta dados científicos e aterrorizantes sobre pobreza. A ciência garante através de números o que o raizeiro formula de maneira intuitiva: o sertão vai mal. Anunciam-se então binômios ligados ao eixo central da entrevista: saber popular/saber cientifico; moderno/arcaico; continuidade/desaparecimento. Na seqüência seguinte, continua o diálogo entre o raizeiro e a "medicina moderna". Ele responde à pretensa eficácia da medicina com descrédito e com a simplicidade de seu conhecimento. Vemos uma imagem, sem som ambiente, de um homem dançando e pulando na frente de cinco músicos de uma banda, como se estivesse se coçando. Ouve-se em off uma continuação da fala do anunciante da feira, listando rapidamente vários tipos de vermes. A voz do raizeiro surge em BG e gradualmente se torna mais audível: "tem mais, eles com coceira toma injeção e daí que aumenta, daí vem compra a raiz e fica bom (sic)".

Sua próxima entrada já é na situação de entrevista. Num primeiro momento, ouve-se o diálogo em off sobre imagens de Sebastião tratando de um cavalo, no quintal de uma casa. Suas falas são intercaladas com trechos de "Asa Branca” cantada por Caetano Veloso; o que, como já discutido em maior profundidade, cria um clima dramático para a situação do animal. Na banda sonora, desenvolve-se o diálogo entra a voz literal do autor e a voz de Sebastião. Ele conta que o conhecimento recebido de seu pai foi somente o de tratar animais e de trabalhar na roça. No trecho seguinte do diálogo, ainda sobre imagens da tentativa dos homens de acalmar o cavalo, a questão medicina/saber popular retorna. O entrevistador pergunta: "Os médicos sabem que o senhor existe?”. Ele responde: “Por ora não sabem porque eu não me estabeleci e nem quero me estabelecer". Depois de mais um trecho em que o tratamento do burro é coberto por "Asa 
Branca", o diálogo é retomado, mais uma vez em off. O raizeiro explica que nenhum de seus filhos quer seguir com a raizada, nem com o tratar de animais, pois "eles só aceita para um velho que não precisa mais trabalhar (sic)".

As questões centrais do diálogo com o raizeiro estão colocadas já neste primeiro momento da entrevista: o conflito entre moderno e arcaico e a preservação da cultura popular. Ao lado disso, a intercalação de diálogos e música - sobrepostos às imagens observacionais do tratamento do cavalo - cria uma dramaticidade que funciona em vários sentidos: dignifica o trabalho do raizeiro, que ganha ares de grande sacrifício; potencializa a precariedade de recursos, e reforça o aspecto negativo da ameaça à continuidade de seu saber.

Em sua segunda parte, a entrevista acontece com sincronia de som e imagem. Sebastião e o dono do cavalo estão em quadro e falam sobre o animal, e sobre o que ele pode ou não fazer. Num segundo momento, na mesma locação, Sebastião está sozinho e explica ao diretor o que o espectador acabou de ver: "Dou uma sangria na boca por modo dela limpar o intestino do bicho, corto a travagem, sangro, desgoverno os quatro pés (sic)". Justificada na primeira parte da entrevista a importância do saber do raizeiro e definida a sua situação ameaçada, nesta segunda etapa, o filme se permite apenas registrar sua experiência e seu saber. Isto fica bem claro algumas seqüências adiante, quando Sebastião retorna e faz uma longa apresentação sobre os tipos de raízes e seus efeitos. Agora a encenação tem outros contornos. Sebastião está posicionado atrás de uma mesa, bem no centro do quadro, onde estão diversas raízes. Olhando para entrevistador, e também para a câmera, ele apresenta cada uma das ervas explicando qual o uso que elas têm, de onde elas vêm, etc. O personagem posiciona-se de uma outra forma, mais expansiva. Ele fala para o público através da câmera, promovendo o seu saber e comandando o ritmo da cena. A narração, por outro lado, endossa essa valorização do personagem, e os planos curtos que predominam no filme são substituídos por longos planos, com poucos cortes e sem música de fundo. 
O mesmo respeito revelado pelo filme, em relação a Sebastião, aparece no registro da rezadeira. Assim como na entrevista do raizeiro, o depoimento de D. Maria também recebe menos intervenções do narrador: não há comentário através da música, colagem com outras cenas, nem qualquer sucessão de planos curtos. A entrevista é longa - tem quase cinco minutos - e constituída basicamente por um único primeiro plano da personagem. Sua entrada principal no documentário é tardia e acontece só aos 28 minutos. Entretanto, assim como no caso de Sebastião, sua presença é anunciada muito antes disso, no início do desenvolvimento, numa seqüência em que um trecho da entrevista cobre a imagem de um artesão trabalhando em uma estatueta de madeira. O entrevistador pergunta: "A senhora conhece alguma destas rezas boas para fechar o corpo?”. No momento, a voz da entrevistada não é identificada, mas numa leitura retroativa entende-se que quem fala é a rezadeira: "Deve ter, mas eu não aprendi não. Memória eu tenho, mas não achei quem me ensinasse". Um plano próximo revela que a estatueta sobre a qual o artesão trabalhava é de Padre Cícero; e é seguido por detalhes da obra já pronta. ${ }^{85}$

A rezadeira só retorna então em sua entrevista. Ela está em primeiro plano, sentada em posição centralizada em relação à câmera, em frente a uma parede de tábuas de madeira envelhecidas. A entrevista toda parece estar levemente fora de sincronia. Ela conta sua idade - mais de cem anos - e diz que aprende suas rezas "com o mundo, o mundo é que me ensina", num exemplo típico de saber popular que não pode ser transmitido através de um ensino institucionalizado. A equipe pede que ela diga uma reza boa e ela começa a falar de uma reza para Santa "Catirina". Numa fala aparentemente automatizada, ela emenda esta oração com mais duas outras, sem interrupções. Há um corte para um enquadramento levemente mais aberto; ela faz mais uma oração e, depois, responde a mais perguntas sobre sua vida. Conta que foi para Santa Brígida ainda criança; que o marido morreu há 30 anos; que ela foi abandonada pelo filho quando ele decidiu ser vaqueiro, e que trabalhou sozinha na roça. A conversa termina quando o entrevistador a pede que diga uma oração para ajudar a plantação. Ela pensa, como quem diz "a

\footnotetext{
${ }^{85}$ Ao lado de todas as referências assumidas a "Deus e o Diabo", me pergunto se não existiria aqui uma leve referência subliminar a Corisco, que, como o filme repete diversas vezes, teve o corpo fechado por Padre Cícero.
} 
seca não se resolve com reza"; e depois de um breve silêncio, começa uma oração para espantar lagartas da plantação.

A ausência de comentários - musicais ou textuais - do narrador indica uma valorização do saber tradicional e posturas nitidamente diferentes do texto em relação à religiosidade popular e em relação à igreja como instituição. A rezadeira recebe um tratamento bastante distinto daqueles das beatas dos dois filmes anteriormente analisados. A câmera é próxima, ao contrário do que ocorre nos depoimentos de devotos em "Frei Damião". A voz literal do autor está interagindo com a rezadeira, sem questioná-la, sem ridicularizá-la e abrindo espaço para que ela manifeste seu saber e suas crenças religiosas. É perceptível um tom levemente paternalista, quando o entrevistador busca uma identificação - que o espectador sabe não ser genuína - com a entrevistada. Quando ele pergunta "a senhora conhece alguma destas rezas boas para fechar o corpo?", seu tom sugere que ele próprio, realmente, acredita no poder da reza; o que, a princípio, soa como pouco verdadeiro. De qualquer forma, o interesse simulado não está ligado a uma crítica subliminar, mas à manutenção de uma dinâmica de encenação, proposta pela própria entrevistada. Diferentemente de Sebastião, ela não está atuando nos moldes de uma relação entrevistador/entrevistado, e sim numa dinâmica entre detentora de saber/aprendiz. Ela parte do princípio de que o entrevistador - com quem se relaciona de forma pessoal e sem a mediação da câmera - está ali buscando aprender com ela; e o entrevistador, por sua vez, respeita esse código da encenação.

Ao mesmo tempo, a voz do texto é crítica em relação à religião como instituição e, numa associação comum a todos os documentários da Caravana, aproxima o poder político e o poder religioso. A sugestão é percebida claramente numa das últimas seqüências do filme, que começa com a imagem de fogos estourando - com som direto -, em frente à fachada de uma igreja à noite. Segue-se um plano de velas acesas no chão, sob sons de fogos e de uma voz em off que pede ajuda a Nossa Senhora das Dores. Há um corte para a entrevista de um político, cercado por vários microfones, à noite. Sua voz não é audível embora haja som ambiente no fundo. Há 
mais um corte para um plano no qual vários rostos populares enfileirados - homens com chapéus de palha, entre os quais um tem na cabeça um papagaio - parecem assistir a um desfile. Sobre a imagem, uma frase musical de Caetano - "mora na filosofia..." - marca a entrada de um policial em quadro, reforçando a idéia de que se trata de um acontecimento oficial. A montagem aproxima a devoção religiosa - na forma das velas e da oração - ao oficialismo do político ou ao possível desfile militar.

No plano seguinte, essa associação é interna à cena. Uma multidão está em frente à igreja de noite. Um grupo de homens engravatados - políticos? - está no fundo e, em primeiro plano, um político cumprimenta autoridades, padres e militares. As forças reacionárias e repressoras aparecem juntas, por assim dizer, confraternizando em cena, numa imagem que é similar a outras vistas nos documentários da Caravana. Na banda sonora, sobre essas imagens, ouve-se Silvio Rodriguez: "viven muy felices -no digo yo/ los que repiten la lección como aprendices/ los que no buscan mas allá de sus narices/ viven muy felices -no digo yo/ los que repiten un camino sin razones/ y ven la audacia como historia de canciones..." ${ }^{\prime 6}$. A música debocha justamente das pessoas que vivem felizes e conformadas com um mundo desigual; das pessoas que não acreditam na audácia e assim por diante. A relação de som e imagem é direta: o comentário musical zomba sutilmente dos representantes do poder que ali estão, em espírito de confraternização. Contudo, em relação à velha rezadeira, a narração é absolutamente respeitosa e a montagem serve ao propósito de transmitir, com a maior fidelidade possível, seu discurso, sem fazer uso de sua fala como mais um elemento orquestrado pela voz do texto; um procedimento padrão em relação a maior parte do material recrutado.

\footnotetext{
${ }^{86}$ Trecho da canção "Viven Muy Felices", de Silvio Rodriguez, músico popular cubano que inicia sua carreira nos anos 60 e é um dos pilares do Grupo de Experimentação Sonora do ICAIC (Instituto Cubano de Arte e Indústria Cinematográficos), onde no início da década de 70 nasceu o movimento da Nova Trova cubana, ao qual se ligavam também Pablo Milanés e Leo Brouwer.
} 


\section{"DEUS E O DIABO" E A DEFESA DA VIOLÊNCIA}

Até este ponto tem sido destacado o aspecto caledoscópico de "De Raízes e Rezas", cuja série de núcleos autônomos de significação dialoga com diversas tendências políticas e estéticas, sem articular uma tese unívoca. Apesar disso, identificam-se no filme algumas sugestões recorrentes de leitura, que geram, por sua vez, um lastro ideológico, contaminando o filme em mais de um momento. Este é o caso, por exemplo, da articulação do argumento pró-violência, que se dá no confronto com extratos de áudio - músicas e diálogo - do filme "Deus e o Diabo na terra do Sol".

"Deus e o Diabo" recupera, em forma de lenda, a tradição de violência pertencente ao movimento interno da historia do sertão, como caminho para o telos da revolução ${ }^{87}$. A violência é apontada como mola propulsora e decisiva do momento histórico. A teleologia do filme coloca a consumação do telos como uma premissa a partir da qual serão ordenados os elementos da narrativa (que em diversos momentos se aproxima do esquema da tragédia clássica). Paradoxalmente, é este fim inescapável - a revolução - que, ao invés de colocar a humanidade numa posição de passividade, garante a ela a condição de sujeito. Em outras palavras, é através da recuperação da liberdade do homem, que pode cumprir-se a profecia revolucionária.

É justamente com esta profecia - ligada à revalorização da violência como elemento sertanejo e verdadeiro motor da mudança - que “De Raízes e Rezas” dialoga, também de maneira ambígua. Ao mesmo tempo em que aceita o pressuposto da violência, parece rever a idéia da revolução como telos inescapável, ao incorporar o "sonho acabou" na perspectiva tropicalista. Nenhuma das utilizações que o filme faz de "Deus e o Diabo" é creditada, mas a referência é explicita e, aparentemente, intencional. Afinal, não é por acaso que Muniz escolhe Othon Bastos - já presente no filme de Glauber nas vozes de Corisco e Sebastião - como locutor dos textos poéticos tanto do autor, como de João Cabral de Melo Neto, no documentário de Sérgio Muniz.

\footnotetext{
${ }^{87}$ XAVIER, 1983 - Capitulo 03.
} 
A primeira referência ao filme surge na seqüência treze, que aborda a produção agrícola, criando uma aparente cronologia causal entre as imagens que retratam as diversas etapas do processo produtivo. Planos de coisas completamente distintas se combinam, reconstruindo num registro ficcionalizante, uma história imaginada. A seqüência tem início com a imagem de uma propriedade rural, onde um homem acompanhado por dois burros, que carregam palha no lombo, anda em direção à câmera, posicionada de frente do portão de madeira pelo qual ele atravessa. Em seguida outros dois homens - diferentes daquele do plano anterior - chegam em frente a uma casinha, carregando palha. Há um novo corte para um menino que coloca palha numa fornalha; e depois há um plano geral da oficina localizada numa área verde, entre coqueiros. Num plano mais próximo, um homem gira uma manivela. Em seguida, vemos planos diversos de produção de mandioca e, finalmente, a imagem de um vaqueiro amarrando um boi.

Toda a banda sonora desta seqüência é formada por um extrato de áudio retirado de "Deus e o Diabo"; do momento em que D. Sebastião fala para seus seguidores no topo do Monte Santo: “Agora eu digo: do lado de lá deste Monte Santo existe uma terra onde tudo é verde. Os cavalos comendo as flor e os menino bebendo o leite nas águas do rio. Os homens comem o pão feito de pedra e a poeira da terra vira farinha. Tem água e comida. Tem a fartura do céu e todo o dia quando o sol nasce aparece Jesus Cristo e Virgem Maria, São Jorge e meu Santo Sebastião...”. E Manoel, o camponês, responde: "É preciso mostrar aos donos da terra o poder e a força do santo".

A relação que se estabelece entre banda sonora e imagem é, numa primeira leitura, de contraste. O trabalho árduo e a dificuldade de plantar estão contrapostos à promessa de fartura, feita por Sebastião. A farinha de mandioca que vemos não é a que surge magicamente da poeira. Assim como o país de São Saruê em “Viva Cariri!" e a crença na redenção, a partir do poder místico de Frei Damião, são vistos criticamente como fugas ingênuas da realidade, também “De Raízes e Rezas" poderia sugerir um olhar crítico em relação à redenção prometida pelos movimentos 
messiânicos, sintetizados no personagem de Sebastião. Por outro lado, o convite para mostrar aos donos da terra "a força do santo" nos remete ao elogio do filme de Glauber Rocha ao poder aglutinador e popular do movimento messiânico. De um lado, "Deus e o Diabo" desmascara e desmistifica o beato Sebastião, mas por outro endossa a força daquele movimento. Analogamente, o documentário desautoriza a sublimação da miséria pela promessa messiânica, mas parece apoiar o questionamento do poder dos donos da terra.

Uma outra referência bastante explícita a "Deus e o Diabo" - desta vez no formato de citação musical - é a seqüência vinte e sete, em que a proposta de resistência ganha contornos mais nítidos na associação com a violência. A seqüência se inicia com uma pan, lenta e constante, sobre uma infinidade de ex-votos numa sala escura. O áudio nos remete ao duelo de Corisco e Antonio das Mortes no final de "Deus e o Diabo": "Se entrega Corisco, eu não me entrego não". Ouve-se Antonio das Mortes: "Se entrega Corisco...". Continua música: "eu não me entrego não/ não me entrego ao tenente / não me entrego ao capitão/ eu me entrego só na morte com o parabelo na mão/ Se entrega Corisco / eu não me entrego não/ não me entrego não". Entra mais um trecho do diálogo: "fortes são os poderes do povo". Continua a música: "Mataram Corisco, balearam Dadá/ Farreia, Farreia povo/ Farreia até o sol raiar...".

Os ex-votos, a esperança de redenção, a expectativa do milagre; tudo isso se confronta com a figura de Corisco, que não se rende e escolhe o conflito. Na seqüência final de "Deus e o Diabo", Corisco é morto por Antônio das Mortes, cuja violência infalível confirma a existência de uma ordem maior. No filme, Sebastião e Corisco representam os dois lados de uma discussão em torno da legitimidade da violência e da reza como formas de contestação da ordem vigente no sertão. Corisco conclui pela violência: "homem nesta terra só tem validade quando pega nas armas para mudar o destino. Não é com rosário não, Satanás. É no rifle e no punhal". Embora o filme desqualifique messianismo e cangaço enquanto práticas revolucionárias capazes de gerar 
justiça, na trajetória do camponês Manuel, o cangaço aparece como um avanço em relação ao messianismo. ${ }^{88}$

O som nos remete à morte de Corisco, ao passo que os ex-votos se impõem imageticamente. Apesar disso, a narração de "De Raízes e Rezas", parece se posicionar ao lado da violência defendida por Corisco - vista como motor da superação histórica - em detrimento da passividade alienante retratada no empilhamento de ex-votos. Isso fica mais claro se o sentido geral criado pela montagem a partir desse ponto for analisado. A morte de Corisco marca a transição para a próxima seqüência, na qual a alienação religiosa retorna em sua desmesura.

Na cena imediatamente seguinte, um homem ajoelhado - parece ser um pagador de promessa caminha por uma estrada de terra, que é mostrada de cima, num plano geral, e pela qual passa um caminhão que desvia do devoto. Neste ponto ouve-se a voz de uma senhora cantando uma música religiosa: "o meu amado menino, ó meu tão belo jasmim, ó leva-me para o céu, ou vinde do céu para mim". Na segunda cena desta seqüência, vê-se uma mulher com um lenço na cabeça, sozinha, dentro de uma imensa construção abandonada em meio a um espaço desértico, onde o chão é de terra vermelha e faz muito sol. Ela tem as mãos unidas em frente ao peito e reza, enquanto em off se ouve uma fala profética - que parece ser desta mesma senhora - sobre como vai ser quando o mundo acabar. Ela levanta as mãos aos céus, e começa a andar em direção à câmera. Quando se aproxima, vemos com nitidez seu rosto pela primeira vez. Trata-se de duas imagens impactantes, que opõe o aspecto devastado do sertão à promessa de redenção religiosa.

Em ambas as cenas, há um contraponto nítido entre a imponência dos dois espaços, e as duas figuras humanas. Os planos mais abertos revelam a dureza dos ambientes em contraste com a pequeneza humana, criando uma grande dramaticidade. Será a fé alienada a única salvação do abandono? O homem e a mulher parecem bastante desequilibrados emocionalmente, em outra

\footnotetext{
${ }^{88}$ XAVIER, 1983, pág 85.
} 
associação típica da Caravana. Enquanto o primeiro áudio ("o meu amado menino...") remete à esperança vã de uma redenção religiosa, o segundo traz imagens terríveis do apocalipse. O sertão é o fim do mundo, e a seca, o final dos tempos. De ambas as formas, definitivamente, a montagem não endossa a esperança de salvação pela fé, que paralisa ao invés de impulsionar o movimento.

A violência, em contrapartida, percorre o documentário que, direta ou indiretamente, explora a idéia de que existe uma violência inerente ao sertão, latente tanto em situações cotidianas como a vida de um vaqueiro - quanto nas relações sociais; e que esta precisa ser assumida como um dado. O cangaço - representado seja pela figura de Corisco, seja pelas manifestações folclóricas que fazem dele simulacro - aparece como uma reivindicação de justiça, que não pode ser esquecida. Um exemplo disso é a seqüência que retrata uma manifestação folclórica onde homens vestidos de cangaceiros dançam batendo bastões de madeira, numa simulação de luta, enquanto se ouve uma música cuja letra é algo como: "dinheiro só, dinheiro só e vem aqui todo lugar/ dinheiro só/ e seu valor ninguém não ganha/ dinheiro só, dinheiro só (2x)/ e a gente na Argentina e na Alemanha/ dinheiro só, dinheiro só/ e domina todo o lugar”. Há um corte para um plano de um dos participantes passando o chapéu por entre o público. Neste ponto, entra a voz de Othon Bastos: “a sanha da violência foi então folclorizada. É quase como se disséssemos que o passado não é de nada". O texto de Othon é de responsabilidade do narrador e nos afirma, de maneira direta, que a fúria gerada pela miséria e pela desigualdade foi sublimada, tornandose simples representação e perdendo sua força de mudança. Os mesmos cangaceiros folclóricos retornam já quando o filme se encaminha para o final, ainda mais inofensivos e aprisionados pela fé. Na banda sonora, ouve-se Caetano cantando um trecho de "Triste Bahia": "pé dentro, pé fora/ quem tem pé pequeno vai embora/ pé dentro, pé fora/ quem tem pé pequeno vai embora/ pé dentro, pé fora/ quem tem pé pequeno vai embora/ ó virgem mãe puríssima/ ó virgem mãe puríssima". Eles estão ajoelhados, cercados por pessoas, e se benzem em frente à imagem de Padre Cícero, em Juazeiro. 
A referência à violência é ainda mais explícita numa longa seqüência que faz, em termos imagéticos, um percurso desde sua folclorização, passando por sua concretização como dado da presente vida sertaneja até chegar a uma projeção de ruptura radical. Vemos inicialmente diversas cenas da produção artesanal de rojões, fogos, ou bombinhas usadas em festas, que têm como trilha uma música não identificada de Milton Nascimento: duas mulheres socam alguma coisa dentro de tubinhos de papéis marrons; uma menina amarra bombinhas em um cordão; imagens de detalhes das bombinhas. A câmera então se movimenta, percorrendo diversos tipos de fogos que estão dispostos no chão da oficina. Neste ponto, a voz de Othon Bastos lê mais um dos textos do autor: "Tiro, fogo, bacamarte. Ferro, fogo, peixeira. Violência à vida inteira, na vida que chega e parte". O tiro do bacamarte e o ferro da peixeira são produtos da tradição de violência do sertão, ainda que destituídos de seu poder real de combate pela folclorização.

O tiro folclórico, no entanto, torna-se mais real, conforme a seqüência tem continuidade. Depois da oficina de fogos artesanais, surge a imagem de uma oficina simples, com tijolos aparentes, onde homens trabalham com ferro e acompanhamos a produção de uma espada, através de vários planos curtos: o ferro em brasa, o artesão sopra o ferro, apaga a brasa e encaixa a peça de ferro na ponta de uma lança, que é martelada e serrada e assim por diante. O comentário musical é feito por Silvio Rodriguez e fala explicitamente de uma ruptura definitiva e total com a história, e que se torna um novo começo: "Este pedazo de la historia/ es aguerrido para ver y reposar/ Parece que es definitivo/ se rompe todo y todo vuelve a comenzar". A voz do texto, que até este momento abre ao espectador a possibilidade de múltiplas leituras, torna-se mais diretiva a seguir. No lugar da voz de Rodriguez, entra uma música instrumental eletrônica - com sons e ruídos repetitivos, agressivos e incômodos - superposta à imagem de uma mão mexendo numa arma que está sobre a mesa de trabalho. Do lado esquerdo, estão quatro armas prontas. A partir deste ponto seguem-se diversas imagens que ilustram a fabricação de revólveres, culminando em um plano geral de um homem sentado em frente à loja, onde espingardas estão expostas do lado de fora e pessoas passam. Em off, sobre as imagens, uma voz não identificada - mas nitidamente 
pertencente a um nordestino simples - diz: "Naturalmente a guerra mundial, tem que ser a guerra mundial. A gente conversa tudo isso, mas lá na frente”.

O uso de uma fala não identificada, como já examinado anteriormente, serve aos propósitos da instância enunciativa, que incorpora como um comentário identificado com o ponto de vista do narrador. Do rojão da primeira imagem, e da sugestão de uma ruptura radical e definitiva no processo histórico, passamos aos revólveres, espingardas e à imagem de uma necessária guerra mundial, bem como ao descrédito em relação a uma solução negociada ("a gente conversa tudo, mas lá na frente"). A fala pode ser remetida diretamente à conversa de Antônio das Mortes com Cego Júlio em "Deus e o Diabo", quando ele evoca a grande guerra "sem a cegueira de Deus e o Diabo", que nada mais é do que a profecia da revolução. No documentário, completa-se então o desenvolvimento do argumento inicialmente sugerido com a citação do filme de Glauber, que se faz presente em diversos momentos do filme, ainda que de maneira não linear: a violência não apenas é inerente à realidade do sertão, como é a única saída.

Vale a pena destacar que Sérgio Muniz já havia feito, em outras ocasiões, referências a questão da luta armada. Em um depoimento a UMESP ${ }^{89}$, ao comentar o documentário "Rastejador" de 1969, Muniz revela a intenção de traçar um paralelo subliminar com a guerrilha: "naquela época como começa a se colocar o problema da luta armada, o subtexto do filme era - logicamente eu não podia pôr isto no letreiro - se a gente quiser ir para o meio do mato sem conhecer o mato, vamos nos dar mal!". Do ponto de vista da montagem de "De Raízes e Rezas", o comentário de Muniz é bastante sugestivo em relação à seqüência que sucede imediatamente a da produção de armas. Trata-se de uma rápida fala de Sebastião, o raizeiro, que se ouve em off, sobre um plano em que ele olha algumas ervas expostas numa barraquinha de feira: "Eu digo como é que você vende raiz sem conhecer, como é que você vende raiz sem ter estudo por modo de conhecer que raiz é?". Tomando-se o comentário de Muniz como ponto de partida, a fala de Sebastião poderia ser lida como "é preciso conhecer o sertão, para poder fazer dele um motor da revolução".

\footnotetext{
${ }^{89}$ (Cadernos de RTV-1/2000)
} 
A questão é ainda desenvolvida ao longo de mais uma seqüência que - após a breve interrupção de Sebastião - retoma a situação do comércio de armas nas feiras. No plano imagético, vê-se um senhor com uma espingarda na mão, sem apontar para ninguém, na feira. Ele conversa com um homem que está de costas e parece ser Sebastião. A seguir, há uma sucessão de imagens de bacamarteiros atirando num descampado, que nos levam de volta ao senhor com a espingarda. Na banda sonora, uma voz muito enérgica em off, de um homem não identificado, afirma que o fanatismo em relação ao futebol é ridículo e conta a história de uma visita de Tostão a uma cidade nordestina, onde a polícia precisou intervir para que a população não invadisse a casa onde ele estava. Ele conclui: "Isto é um fanatismo mundial, isto é escandaloso, isto é ridículo, a um jogador de futebol”. A sua fala é firme e séria, mas, na articulação da montagem, o que se cria é um comentário bem humorado e irônico, condenando o fanatismo à medida que ele é alienado, mas endossando a agressividade contida no tom do depoente. Visualmente, os tiros de bacamarteiros simulam a ação revolucionária da qual o folclore é simulacro, situando esta ação no final da cadeia de associações que teve início na produção de rojões.

“De Raízes e Rezas” conta ainda com outra citação de “Deus e o Diabo”. Nessa última situação, no entanto, a profecia revolucionária não é absoluta, dialogando de um lado com o tropicalismo e, de outro, com João Cabral de Melo Neto. A seqüência explora o tema da morte e, do ponto de vista da evolução da montagem, está localizada logo depois da longa seqüência da violência, fazendo uma transição para seqüência que cita a morte de Corisco (ambas analisadas acima). Seu ponto de partida é uma série de quatros planos que mostram uma mulher sentada ao lado do leito de seu filho doente; cobertos pela voz de Gal Costa ao fundo, que grita: "É preciso estar atento e forte, não temos tempo de temer a morte" ${ }^{90}$. Ainda sobre estas imagens iniciais entra voz Othon Bastos em off, desta vez na pele de Corisco: "Eu, José, na espada de Abraão serei coberto/ eu, José, com o leite da Virgem Maria serei borrifado/ Eu, José, com o sangue de Cristo serei batizado". Trata-se de uma fala que Corisco diz, numa espécie de ritual teatral que antecede

\footnotetext{
${ }^{90}$ Trecho de “Divino Maravilhoso”, música de Caetano Veloso e Gilberto Gil, gravada por Gal Costa em 1969.
} 
seu duelo com Antonio das Mortes, mas a impressão é de que Othon regravou esse texto especialmente para o documentário.

Vê-se um homem doente, deitado em um carrinho puxado por um burro e por um menino, que anda no fim da feira. No primeiro plano, vemos o carrinho se movimentando em direção oposta à câmera. No plano seguinte, o carrinho passa em frente à câmera. Vê-se o menino, o burro, depois um detalhe do rosto do homem, que parece mumificado, até que o carrinho se afasta. Em off, a narração de Othon continua: "Eu, José, na arca de Noé serei guardado/ eu, José, com a chave de São Pedro serei fechado/ Onde não me possam ver, ferir e nem matar".

O que se observa no plano visual é uma sucessão de cenas relacionadas à doença. E na banda sonora uma colcha de retalhos entre Othon/Corisco em sua oração ritual; o chamado de atenção de Gal Costa; e Othon/locutor que lê trechos de "Morte e Vida Severina". A citação de João Cabral surge sobre a cena de um fotógrafo que ajeita o rosto de um religioso morto. Ele está num caixão aberto cercado por pessoas que posam para a foto. Othon diz: "como aqui a morte é tanta, só é possível trabalhar nas profissões que fazem da morte ofício ou bazar; só os roçados da morte compensam aqui cultivar. Simples questão de plantar...".

Neste ponto, há um corte para o plano geral de um cortejo que acompanha o caixão de uma criança. Algumas pessoas seguram cruzes; músicos acompanham, e duas meninas seguram o caixão. Na banda sonora, o texto de João Cabral prossegue - "(...) a morte que se morre de velhice antes dos trinta, de emboscada antes do vinte e de fome um pouco por dia" - para, em seguida, a frase musical tropicalista retornar. No ápice da seqüência, acompanhamos a chegada do cortejo ao cemitério e o enterro acompanhado pela zabumba, que toca o hino nacional. ${ }^{91} \mathrm{Um}$ menino está agachado ao lado do túmulo e uma menina, em pé, à sua esquerda olha para câmera. Ele a cutuca, como que se dissesse "não podemos olhar para a câmera!". A impressão

\footnotetext{
${ }^{91}$ Ver comentário de Sérgio Muniz sobre problemas com a censura relacionados a esta cena na página 02 deste trabalho.
} 
que se tem é que os dois estão ali - todos os outros participantes já caminham em direção à saída - a pedido da equipe de filmagem, que pede para eles ignorarem a presença da câmera. Mas a menina, ao encarar o público, rompe este acordo.

Múltiplas questões se colocam a partir dessa seqüência. Em primeiro lugar observa-se, pela reiteração excessiva da morte e da doença em termos imagéticos, o reconhecimento da morte como um dado básico da cultura nordestina, bem na linha do que Sarno faz em "Viva Cariri!". Esta idéia é expressa de forma precisa pela citação de João Cabral que fala da "morte que se morre de velhice antes dos trinta, de emboscada antes do vinte e de morte um pouco por dia". A citação de "Morte e Vida Severina" tem, assim, a função de comentário diagnóstico, apresentando um dado concreto sobre a realidade nordestina. No entanto, na banda sonora, outras mortes estão sendo enunciadas: a morte de Corisco, etapa inevitável no caminho da revolução, na voz de Othon/Corisco; e a morte que não deve ser temida, na voz de Gal Costa.

São sintetizados aí os dois movimentos centrais e opostos do filme. Do ponto de vista da alegoria profética, a morte de Corisco é a morte do cangaço, que precisa ser superado para abrir caminho para a mudança; embora sua reivindicação de violência precise ser incorporada. De outro lado, "Divino Maravilhoso" é um chamado de atenção para o aqui e agora da vida, onde "tudo é perigoso e onde tudo é maravilhoso". É preciso estar atento, repete a música, para tudo que nos cerca, sem ter medo. No entanto, o refrão, o "samba exaltação" e a palavra de ordem são igualmente merecedores de atenção, num movimento que não hierarquiza o discurso explicitamente político nem a discussão estética da canção. O chamado para o aqui e agora é absolutamente distinto da expectativa da revolução como resultado, que parte do passado para o futuro deixando o presente como indeterminação. De um lado, o embate e a violência aparecem como únicas saídas; de outro, esse confronto se dá no aqui e agora da vida, e não no futuro idealizado da profecia. Mais do que isso, o embate não se resume, do ponto de vista do texto, ao horizonte político da revolução. Ele é também um movimento de ruptura estética: está na 
violência com que a voz do texto se afirma, sem pudores, e na antropofagia de referências múltiplas do passado e do presente da cultura brasileira.

No diálogo entre estes dois olhares, é interessante notar o enfrentamento que a menina do cemitério faz com a câmera. A cena, do ponto de vista de criação de sentido, serviria perfeitamente à articulação promovida pela voz do texto; contrastando o hino nacional - de exaltação ufanista - e a morte como princípio básico na vida do sertanejo nordestino, e criando um clima dramático. Entretanto, a menina rompe com o roteiro pré-estabelecido e encara risonha a câmera, colocando em risco sua função de atriz natural e denunciando a encenação. Logo é repreendida pelo menino, que tenta manter a cena conforme planejada. Contudo, justamente por revelar a existência de um planejamento, o menino confirma ao espectador que os acontecimentos aos quais eles assistem não se reportam a eles mesmos, mas a um enunciador real. A cena, mantida na montagem, resume a tensão entre os diversos impulsos da voz do texto. O desejo de construir a crítica sociológica ainda está lá, mas tem que conviver com o questionamento sobre a possibilidade da representação objetiva e com a afirmação contínua da própria instância enunciativa que comanda o texto.

A partir desta seqüência sobre a morte, o documentário começa a se encaminhar para seu fechamento. Ela é imediatamente seguida pela seqüência da morte de Corisco e, depois, pelas imagens de fé alienada, pela entrevistada da Rezadeira, pela cena em que o grupo folclórico se benze e, finalmente, pelo encontro das forças dominantes e repressoras em frente à igreja (seqüências que foram analisadas separadamente acima). Contudo, me parece importante observar seu encadeamento, para melhor visualizar os termos em que este painel está sendo organizado. Em relação aos núcleos de sentido, pode-se avaliar este percurso como uma seqüência de contrastes ligados aos dois movimentos opostos do filme. Partimos do diálogo entre a morte anunciada de Corisco (que é a prefiguração da revolução) e do aqui e agora tropicalista, para o contraste entre a fé alienada e institucionalizada (os dois devotos em lugares de abandono) e a religiosidade como dado relevante a ser preservado da cultura popular 
(rezadeira). Passando pela sublimação da violência através do folclore, o filme chega à reafirmação das forças repressoras, no encontro entre políticos, padres e militares, no qual a banda sonora faz lembrar que os que dominam estão muito satisfeitos com a ordem vigente. $\mathrm{O}$ impulso de mudança então precisa vir através da legitimação da violência.

Na seqüência seguinte, surge uma imagem otimista: um plano geral de um rio que corre cheio ao lado de um vale verde, remetendo por oposição à imagem do rio no início do documentário. $\mathrm{Na}$ banda sonora, ouve-se um repente: "quem nunca comeu feijão e farofa com carne assada/ não fundou um boi de açude/ não correu em vaquejada/ nasceu (...) e morreu e da vida não gozou nada". A terra verde, o rio cheio de água - em contraponto ao rio quase seco da abertura e o áudio de repente recuperam a relação de prazer e valorização de aspectos da cultura popular. A dúvida que se estabelece é se esta imagem estaria colocada, do ponto de vista da voz do texto, no aqui e agora ou numa projeção futura. Trata-se de uma promessa na chave do "sertão vai virar mar" de Deus e o Diabo? Ou seria uma re-significação da tradição cultural para o entendimento do presente? Esta é uma resposta que a voz do texto não impõe. Depois da imagem do vale, o filme retorna ao registro da pobreza e da precariedade. $\mathrm{O}$ vale não se confirma, sendo então a expectativa de redenção não realizada. A câmera caminha por entre pessoas que cercam um homem negro, sem uma das pernas. Ele está sentado no chão, falando e gesticulando. Um movimento de câmera revela duas pernas de madeira velhas e descascadas em frente ao homem. E, ao lado delas, duas notas de dinheiro. A câmera volta até rosto dele e sobe, pelo rosto de um menino, até sair da roda; mostrando uma mulher de lenço que passa e um moço sentado ao lado de um carrinho de picolé. Na banda sonora, não há som ambiente e, sobre as imagens, escuta-se a voz de Caetano Veloso repetindo o verso final de "You Don't Know Me": "Eu agradeço/ ao povo brasileiro/ norte, centro, sul inteiro/ onde reinou o baião (...)". ${ }^{92}$

A música, mais uma vez, funciona como comentário do narrador que, novamente, se assume como tal e agradece ao povo brasileiro, a matéria prima da representação. Após um fade to

\footnotetext{
${ }^{92}$ Música gravada em Transa (1971/1972)
} 
black, entra a cartela final - "Acabou" - ao som de Gilberto Gil: "o sonho acabou, foi pesado o sonho para quem não sonhou". ${ }^{93}$ Nessa rede de referências o "acabou" da cartela cria diversas possibilidades de leitura. De um lado, após os agradecimentos, "o sonho acabou" se refere literalmente ao final do documentário e à sua dimensão de representação alegórica. Mas a frase nos remete também ao sonho da revolução, enterrado após o golpe de 1964, e ao posterior recrudescimento da ditadura. Ao mesmo tempo, na voz de Gil, a frase vem carregada do deboche tropicalista em relação ao sonho frustrado da esquerda, tornando o fracasso um dado a partir do qual a realidade pode ser confrontada por uma nova sensibilidade. Assim, o documentário acaba sem fornecer ao espectador uma chave única de leitura, articulando dois pólos absolutamente distintos de entendimento do país, dos quais ele se aproxima e se afasta ao longo de seu desenvolvimento, sem se comprometer definitivamente com nenhum.

A montagem caledoscópica de Muniz, dessa forma, radicaliza as tendências de transição que "Viva Cariri!" e "Frei Damião" anunciam, incorporando de forma mais efetiva alguns procedimentos que carregam a vitalidade daquele momento histórico no qual ele se inscreve. Sua maior inovação talvez seja o fato de assumir, explicitamente, a voz do texto como instância organizadora do material fílmico. Em “De Raízes e Rezas” a voz do texto manipula livremente som e imagem criando significados múltiplos. Diferencia-se assim, completamente, da também afirmativa voz do texto do "modelo sociológico"; que se apresenta de maneira autoritária, e mascara a hierarquização do material fílmico em vista da comprovação de um argumento. As possibilidades de diálogo, entre voz do texto e o material que ela organiza, se diversificam, através de diferentes níveis de interferência e controle. No que diz respeito às entrevistas, se observa também uma alteração significativa das dinâmicas de entrevistador/entrevistado e de voz do texto/voz do depoente, caminhando para uma maior valorização da subjetividade do entrevistado popular.

\footnotetext{
93 "O sonho acabou" é de autoria de Gilberto Gil e integra o disco Expresso 222, de 1972, o primeiro trabalho realizado por Gil depois de sua volta do exílio.
} 


\section{CONCLUSÃO}

Essa dissertação buscou, através da análise vertical de três filmes da Caravana Farkas, situar esta produção em relação à tradição documentária brasileira que a antecede, em especial o documentário expositivo de vocação sociológica, e às novas tendências que começam a ser observadas mais claramente ao longo da década de 70. Nesse movimento, o que se torna perceptível é que esse corpus da Caravana Farkas pode ser caracterizado como de transição, no sentido em que apesar de estar ainda fortemente ligado às raízes do dito "modelo sociológico" brasileiro, e ao paradigma da "voz do dono", aponta para procedimentos que se tornarão mais comuns na produção brasileira posterior, onde a busca da "voz do outro" ganha consistência. Entre os três filmes analisados percebe-se que “De Raízes e Rezas, entre outros” é aquele que vai mais longe neste percurso, ao acentuar elementos esboçados em "Viva Cariri!" e em "Frei Damião”.

Gostaria de observar duas coisas. Em primeiro lugar, é bom lembrar que essa seleção de três filmes, não reflete o todo da produção da Caravana Farkas, que de maneira geral é menos inovadora e se apóia fortemente na abordagem expositiva, insistindo numa dimensão de registro ingênuo da cultura popular. Ao lado disso, é importante destacar que as análises levaram em conta as mudanças fundamentais de contexto sócio-político, que certamente são refletidas num re-posicionamento - o diagnóstico indiscutível é substituído pela falta de certezas - dos documentaristas em relação à realidade. Entretanto, o movimento de análise parte do material fílmico para questões de contexto e não o contrário, deixando aberto este enfoque de pesquisa para outros trabalhos.

Buscando contribuir para uma maior caracterização deste período de transição, gostaria de sistematizar aqui alguns elementos chaves já discutidos nas análises: o tratamento dado à religião e à cultura popular; a articulação de uma tese de fundo; o uso na narração em off; o nível 
de afirmação da voz do texto; o uso de entrevistas; o uso de estratégias observacionais e os modos de produção de sentido na relação espectador-filme.

No que diz respeito à abordagem do documentário brasileiro em relação à religião pode-se observar um movimento da "religião objetiva", característica da primeira metade da década de 60, em direção à "religião subjetiva" que começa a aparecer na década de 70. Em outras palavras, de um pólo a outro, se nota uma gradual valorização e abertura de espaço para a experiência subjetiva da fé, em oposição ao registro da de rituais coletivos, envolvendo grandes massas de fiéis, onde se destacam o panorama sociológico e o paradigma da alienação.

Os três filmes aqui analisados relacionam-se com estas duas tendências de diferentes maneiras. Em "Viva Cariri" a "religião objetiva" ainda predomina, seja através das imagens de Cícero, o penitente, ou de constantes sugestões da voz do texto no se sentido de associar a figura do dominado à alienação religiosa. Existem relatos de experiências pessoais de fé, como por exemplo, a entrevista da guardiã dos ex-votos, mas estas experiências se subordinam ao narrador, colaborando para a confirmação da associação entre fé e alienação. A religião aqui é abordada de um ponto de vista mais genérico, como elemento fundamental para o entendimento do esquema de dominação política e econômica da região.

Em "Frei Damião", o foco religioso é mais preciso e o filme discute o fenômeno do beatismo ao redor de Frei Damião do ponto de vista do fanatismo religioso estimulado pela igreja. A associação entre poder político e religioso está presente, como na maior parte dos filmes da série. O documentário aborda a "religião subjetiva", a partir de diversos depoimentos de fiéis em relação a milagres do Frei. O que acontece, no entanto, é que esses depoimentos não contam com a solidariedade do narrador, que trabalha na articulação de uma tese alheia a eles e altamente crítica ao beatismo. Para ilustrar essa tese de fundo a narração articula ainda imagens de "religião objetiva"; isto é, a observação de manifestações coletivas de devoção, que apresenta o fanatismo "como ele é". 
Finalmente, em “De Raízes e Rezas”, apesar de ambos os registros estarem presentes, nota-se um elemento novo. O filme apresenta a religiosidade popular do ponto de vista de uma experiência subjetiva de fé, legítima e valorizada, através do depoimento da rezadeira Maria. Sua experiência pessoal é ouvida, recebendo poucas interferências da montagem, que não busca articular uma tese de fundo. Por outro lado, a associação entre a dominação política e religiosa ainda se faz presente, bem como uma crítica à igreja como instituição.

Esse elemento inovador se deve a uma diferença básica entre os três documentários. Enquanto "Viva Cariri!" e "Frei Damião" ainda preservam a tese de fundo, característica do documentário expositivo, em "De Raízes e Rezas” há uma estilhaçamento desta tese. É claro que a exposição de uma tese já não se dá como antes. No filme de Sarno o argumento central não é exposto pela narração em off e sim construído, de maneira menos linear do que no dito "modelo sociológico", pela montagem. Através do contraste entre seqüências aparentemente desconexas, Sarno mostra que a modernização do Vale do Cariri colide com os resíduos de cultura popular e o modelo de organização social e econômica locais, onde religião e política são interfaces de um mesmo modo de dominação. Em "Frei Damião", Paulo Gil também mascara sua tese de fundo. Ao invés de afirmá-la, o filme a esconde através da pergunta: “quem é Frei Damião?”. A resposta se apresenta a partir do aparente endosso da visão popular de que ele é um santo, até o filme nos levar a concluir que ele é uma atualização do fenômeno do fanatismo - repetindo o que já se viu em relação de Padre Cícero -, que na realidade é positivo para a igreja. Já em "De Raízes e Rezas" não se localiza mais uma tese unívoca a partir da qual o material fílmico se organiza. $\mathrm{O}$ que se observa é uma multiplicidade de argumentos e uma pulverização da crítica social em núcleos autônomos de significação.

A pergunta seguinte seria: quais as transformações dos modos de afirmação da voz do texto em cada um desses filmes, uma vez que a articulação da tese por uma voz em off autoritária e arrogante já saiu de cena? Quais são os novos modos de organização do material fílmico para 
que, de um lado, afirme-se uma tese de fundo e, de outro, essa afirmação seja feita de maneira menos explícita? No modo expositivo, existe um alto nível de afirmação da voz do texto, fortemente identificada com o narrador em off que conduz a construção do argumento. Todos os elementos fílmicos se subordinam a esta instância enunciadora: as imagens, as entrevistas, a música, etc.

A primeira alteração significativa que se nota, nos três filmes analisados, é um gradual desaparecimento do narrador em off. Em "Viva Cariri!" o locutor tem seis entradas, mas não é responsável pela articulação da tese. Sua função é apresentar algumas informações básicas sobre a economia e organização social do Vale, sem julgar ou criticar o que é apresentado. Em "Frei Damião" o espaço do locutor é ainda menor. Existe apenas uma entrada da voz em off, no início do documentário, que apresenta o fenômeno de Frei Damião e coloca a pergunta a partir da qual o filme se organiza. Numa leitura retroativa do filme torna-se óbvia a crítica que se esconde na leve ironia deste comentário inicial, mas na realidade ela é apenas sugestiva. Quem de fato articula a tese é o encadeamento da montagem. A narração em off é definitivamente suprimida em "De Raízes e Rezas", para paradoxalmente, haver uma ainda maior afirmação do narrador, seja através do uso da música como comentário ${ }_{2}$ ou da leitura por um locutor de alguns textos de caráter poético do autor - indícios que funcionam como indicações de leitura. Em todos os casos, a voz literal do autor começa a se fazer presente - de forma parcial em "Viva Cariri!" e "Frei Damião" e total em "De Raízes" - no momento da entrevista, como se verá em mais detalhe a seguir.

De nenhuma maneira, no entanto, a retração na narração em off se traduz num enfraquecimento da voz do texto. No caso de "Viva Cariri!", por exemplo, nota-se um alto nível de afirmação da voz do texto, através de uma combinação da locução, depoimentos altamente dirigidos, depoimentos autônomos (que aparentemente se organizam sem a interface do entrevistador) e de imagens captadas através de estratégias observacionais. Existe uma nítida hierarquização entre os elementos recrutados pelo filme e, no caso dos depoimentos, a 
submissão da experiência subjetiva em relação à voz do texto. $\mathrm{Na}$ análise foi incorporada a noção de "locutor auxiliar", em casos onde o narrador permite uma identificação de outras vozes com a instância enunciadora e se apropria destas vozes para a construção do argumento. Em outros casos - como o da beata guardiã de ex-votos - a noção foi estendida para a idéia de “não-locutor auxiliar". Isto é, a partir justamente da incapacidade de elaboração de argumento por parte de alguns entrevistados, se comprova a conexão entre religião e alienação, que, no caso destes documentários, amplia a idéia de alienação política para um quase autismo em relação ao contexto.

Se de um lado, no encadeamento discursivo, afirma-se a voz do texto, de outro, sistematicamente, acontece uma tentativa de apagamento ou mascaramento do enunciador através de estratégias observacionais e da não-linearidade da montagem. As estratégias observacionais se fazem presentes nas seqüências narrativas autônomas, que atuam como comentários do narrador, e no registro da história do penitente. Neste segundo caso câmera e equipe se colocam de um ponto de vista externo à cena, que se desenrola sem a sua interferência. Em geral, o uso de imagens observacionais com baixo nível de interferência do narrador potencializa o aumento do "efeito verdade", ou seja, da sensação de que o que se observa é a captura da própria realidade, como ela é. O apagamento do enunciador gera uma mudança no modo de produção de sentido por parte do espectador, apoiando uma leitura ficcionalizante que se baseia na sugestão de que os fatos falam por si, sem nenhum tipo de agenciamento. No conjunto da montagem essas imagens tem o duplo efeito de corroborar a tese e mascarar sua articulação.

Em "Frei Damião" ao mesmo tempo em que a narração em off perde ainda mais espaço, a voz do texto se afirma com força através de um alto nível de controle sobre os depoimentos, que constituem a base do documentário. Os depoimentos se dividem em dois grupos: depoimentos de populares, onde autor se omite e, aparentemente, empresta à personagem da fanática o papel de agenciadora da realidade, e a entrevista de Frei Damião onde a voz literal do autor está 
presente, e se estabelece um confronto ideológico entre entrevistador e entrevistado. Em ambos os casos, a afirmação da voz do texto é clara. A omissão do narrador em relação aos depoimentos populares é altamente ideológica e tem a ver com o movimento da montagem que parte do endossamento irônico da visão popular para o "desmascaramento" do Frei.

Já na entrevista com o Frei, uma combinação de recursos é utilizada. A voz literal do autor, altamente identificada com a voz do texto, parte para o confronto: provoca, questiona e apresenta sugestões claras de que a Igreja estimula o fanatismo. Aliada a ela está à montagem, que recorta o depoimento do Frei potencializando suas dúvidas e confrontando suas afirmações com imagens observacionais, que pretendem mostrar a existência do fanatismo. Assim como em "Viva Cariri", as estratégias observacionais funcionam no sentido de apagar o enunciador e potencializar a sensação de acompanharmos as coisas como elas são. Com isso cria-se, através da montagem, um contraponto entre o personagem de Frei Damião, que personifica o discurso religioso e minimiza o fanatismo, e a realidade observada sem filtros, que o desmente. $\mathrm{O}$ documentário assim se situa num ponto médio entre a "voz do dono" e a "voz do outro": ao mesmo tempo em que há um distanciamento do autoritarismo da voz em off expositiva e uma incorporação de experiências subjetivas, todos os elementos fílmicos ainda trabalham na comprovação de uma tese de fundo, e a voz do oprimido ainda é desconsiderada pelo narrador, que não estabelece com ela um diálogo horizontal.

Nesse percurso entre dois modos de realização documentária, "De Raízes e Rezas" - até mesmo por uma questão de contexto de produção, já que é uma edição tardia do material da Caravana - avança alguns passos. O que se observa é uma alta afirmação da voz do texto que, paradoxalmente, trabalha no sentido de minimizar o autoritarismo do locutor do documentário sociológico. A instância de enunciação manipula assumidamente, e de forma completa, o material fílmico para a construção de um registro que demanda autonomia em relação à realidade da qual se utiliza. Não se trata mais de apresentar ao espectador a realidade como ela é - seja através da tese sociológica ou da observação não interferente - mas sim de apresentar uma 
leitura da realidade de acordo com o ponto de vista de um enunciador que se assume como tal. O documentário não se propõe a ser uma porta de entrada para a realidade, mas sim uma representação mediada. Comentários musicais, textos em off, citações de filmes, falas curtas: tudo pode ser remetido à instância enunciadora. A proposta - anunciada numa das cartelas que abre o filme - é utilizar a realidade como ficção. Assim, a voz do texto sobrepõe a imagens observacionais músicas que atribuem climas dramáticos, bem-humorados ou de suspense, ao que se vê. Em outros casos cria seqüências nas quais se observa uma cronologia causal entre elementos completamente díspares, criando uma continuidade fantasiosa entre ações fragmentadas. Não pelo apagamento do enunciador, mas justamente por sua afirmação é que se cria então a possibilidade de que o espectador "vibre ao ritmo dos acontecimentos", num modo ficcionalizante, como sugere Odin.

No que diz respeito à tese observa-se a ausência de um argumento para o qual a organização de todo o material recrutado converge. Existem argumentos diversos, pontos de vista variados, com os quais o filme dialoga enquanto realiza um levantamento de temas e imagens do Nordeste. $\mathrm{O}$ artesanato, a religião, a agricultura, a violência, o saber tradicional, a migração, entre diversos outros temas, estão presentes e são apresentados em núcleos de significação que se desenvolvem de maneira independente. Alguns argumentos adquirem, no entanto, maior lastro ao longo do filme, apontando para certas sugestões recorrentes de leitura propostas pela voz do texto; como é o caso do argumento pró-violência que se desenvolve em mais de uma seqüência. A ausência de uma tese unívoca tem também relação direta com o fato de que o filme navega entre dois pólos estéticos e ideológicos: a profecia da revolução de "Deus e o Diabo na Terra do Sol" presente através do empréstimo de diálogos e música do filme - e o tropicalismo, que responde à crise das totalizações com deboche e ironia - presente no filme através do comentário musical.

O uso de trilhas tropicalistas na banda sonora marca uma outra diferença de "De Raízes e Rezas" em relação aos outros dois filmes, por incorporar um elemento externo à realidade retratada no comentário. Em "Viva Cariri!", por exemplo, a voz de Gilberto Gil surge nos créditos de 
abertura e de fechamento - momentos do filme onde o agenciamento do enunciador é um dado. Ao longo do filme, no entanto, se observa uma pequena utilização de músicas na trilha sonora, com exceção da cantiga popular que descreve São Saruê - expondo uma dimensão ingênua do cordel, que se transforma em comentário irônico através de sua identificação com o comentário -, de um jingle de uma marca de sandálias produzidas no Nordeste e de orações e ladainhas religiosas. Em "Frei Damião", com exceção da música de Pífanos do Caruaru, que abre o filme e que retorna sobre as imagens observacionais da visita de "Frei Damião" do fechamento, Paulo Gil não utiliza música de fundo. Já em "De Raízes e Rezas” a relação é outra. A trilha sonora faz às vezes de comentário e tem uma presença massiva ao longo do filme. $\mathrm{O}$ folclore e as ladainhas populares ainda existem, mas ao lado deles estão músicas tropicalistas, canções de protesto e uma canção de "Deus e o Diabo". A criação de sentido se dá justamente a partir do contraste entre a banda sonora - que traz em si um olhar externo, não identificado com o universo retratado nas imagens - e as imagens em si.

Parece-me importante notar aqui uma mudança sutil de tratamento. O uso de material folclórico ou identificado com o universo de cultura popular retratado está vinculado a algumas idéias. Em primeiro lugar, identifica-se uma herança do Cinema Novo e da discussão sobre um "cinema popular". Seria importante incorporar criticamente elementos da cultura popular "alienada" para legitimar a condição "popular" desse cinema; bem como para criar uma espécie de porta de entrada para a comunicação com o povo mesmo, através de um mecanismo de identificação. Em segundo lugar, existe também a tentativa de aumentar a veracidade da representação, sugerindo a existência de uma fidelidade entre recursos utilizados e realidade observada, minimizando a interferência de elementos externos a essa realidade. Embora, evidentemente, estes cineastas se relacionem com a realidade observada a partir de um distanciamento intelectual inerente à condição de observadores externos, existe ainda certa resistência em admitir elementos estranhos à realidade retratada, que assumam esse distanciamento e possam deslocar o filme de seu papel ideal de mecanismo de revelação da realidade. 
Sérgio Muniz, ao invés de mascarar este estranhamento entre o universo intelectual do cineasta e a realidade observada, escolhe acentuar o contraste como forma de enriquecimento do documentário. A cultura popular está presente através do recrutamento direto (cordel, orações), mas principalmente através das releituras tropicalista, cinema-novista ou erudita, mais identificadas com o universo cultural do autor. Luiz Gonzaga está lá, bem como a cantiga de capoeira, mas na voz de Caetano Veloso. O bumba-meu-boi surge, mas já transformado no bumba-iê-iê-iê tropicalista. Corisco e Lampião marcam presença, mas na síntese alegórica de Glauber Rocha. O ponto de vista do retirante também está ali, mas na sociologia poética de João Cabral de Melo Neto em "Morte e Vida Severina". Assim, Muniz avança no sentido de estabelecer uma relação mais transparente entre o ponto de vista do enunciador e do objeto do filme $_{2}$ que é a própria cultura popular. Ao assumir o estranhamento, Muniz também avança ao propor, por alguns momentos, uma visão mais positiva da arte popular como uma fonte de prazer que não necessariamente é alienante, preservando uma dimensão crítica. Sempre num movimento pendular, em outros momentos, Muniz critica a sublimação da "sanha da violência" através da folclorização. De qualquer forma, num pólo ou no outro, o filme dialoga com menos altivez em relação à cultura popular, que pode ser atualizada e não está congelada no registro audiovisual.

Como observado ao longo da dissertação, existe na Caravana Farkas de maneira geral um impulso forte na busca de registrar aspectos arcaicos da cultura popular nordestina ameaçada pela modernização. Essa missão de preservação através de uma espécie de etnografia audiovisual, que é muito clara no conjunto de filmes, se manifesta nos documentários analisados de formas diferentes. Em "Viva Cariri!", o mapeamento de atividades ligadas à cultura popular manifestações folclóricas e religiosas, o artesanato, métodos rudimentares de produção agrícola - está presente, mas o filme procura se relacionar criticamente com estas experiências. O diagnóstico de Sarno é pessimista e aponta para a decadência inevitável desses sistemas. "Frei Damião", por sua vez, não tem nenhum tipo de apego em relação à religiosidade popular, que é 
o tema central do filme. A busca de registrar - através de imagens observacionais - o fanatismo, não pode ser confundida com um desejo de preservá-lo. Ao contrário, o fenômeno é entendido pelo filme como um dado recorrente da cultura nordestina, sendo assim apresentado em sua dimensão paralisante e de entrave da superação histórica. Assim, o registro está ligado aqui a um movimento de ruptura e não de preservação.

“De Raízes e Rezas" retoma a questão da permanência da cultura popular - que é especialmente presente no conjunto de filmes de Muniz - em duas vertentes. De um lado, o núcleo central do filme, constituído pelas entrevistas da rezadeira e do raizeiro, carrega o impulso básico de registrar duas experiências que estariam prestes a desaparecer (ainda que esse temor do cineasta não tenha se comprovado inteiramente, já que ambas as atividades resistem ainda em diversas localidades nordestinas). Além disso, ao longo do documentário, proliferam imagens de muitas atividades ligadas à cultura sertaneja formando um grande painel temático que de certa forma sintetiza todo o esforço da Caravana em registrar essa cultura popular. Ao mesmo tempo, por optar pelo ensaio em detrimento de uma pseudofidelidade da representação, Muniz insere vitalidade e atualidade naquilo que registra. Isto é, o folclore e a religiosidade deixam de ser elementos marginalizados e ameaçados, para dialogarem com manifestações artísticas contemporâneas ao filme e pertencentes ao aqui e agora daquele momento histórico. $\mathrm{O}$ paternalismo ingênuo em relação não apenas a produção cultural popular, mas também em relação aos grupos sociais responsáveis por essa produção, dá lugar para uma horizontalidade do diálogo.

Como já comentado acima, nos três filmes a entrevista surge como um procedimento básico e estruturante, antecipando um pouco o documentário de entrevistas - mais comum a partir das décadas de 70 e 80, e até hoje presente na televisão de maneira geral - que restitui a enunciação direta, usando o depoimento no lugar da voz em off autorizada. Neste tipo de abordagem, é a articulação de testemunhos pessoais que estrutura o documentário como um todo, num movimento que muitas vezes acarreta no apagamento da voz do texto por trás dos personagens. 
Os atores sociais - quase sempre personagens comuns - se dirigem diretamente ao espectador, revelando a confiança dos cineastas na história oral para a reconstituição do passado. Neste sentido, o documentário que mais se aproximaria deste modelo é "Frei Damião", que usa a entrevista como procedimento básico. Ao mesmo tempo, essa aproximação não é completa, pois o argumento que a montagem desenvolve é exterior aos entrevistados e não surge a partir de suas experiências. O testemunho pessoal ainda se vê subordinado a um julgamento histórico construído pela voz do texto, que o exclui. No caso dos entrevistados populares, como observado na análise, existe um resíduo de certo paternalismo em relação a extratos mais baixos da população, desconsiderados como interlocutores. A voz do texto não endossa suas experiências, mas tampouco se preocupa em confrontá-las diretamente, já que são frutos da ignorância. $\mathrm{O}$ embate se dá no momento em que o diálogo acontece de modo horizontal, quando o interlocutor é Frei Damião, ele sim, um adversário ideológico. De qualquer forma, com ou sem a presença da voz literal do autor, a montagem se encarrega de balizar o material apresentado, de acordo com seu ponto de vista.

Em “Viva Cariri!” também existe uma clara subordinação dos testemunhos à voz do texto, de duas maneiras diferentes. Em algumas situações a voz literal do autor está presente e essa hierarquização se apresenta já no momento da entrevista, quando o autor direciona o diálogo para a construção de seu argumento. Em outros momentos, a voz do autor se apaga e cria-se inclusive certa dúvida sobre a origem da fala apresentada. Nestes casos, mais uma vez, os depoimentos servem de apoio para a construção de uma tese que - embora em alguns momentos guarde semelhanças com os pontos de vistas de outras vozes - é de responsabilidade do enunciador. A diferença de propósitos entre autor e entrevistados é recorrente, mas tem uma manifestação clara na entrevista da guardiã de ex-votos onde duas dinâmicas se opõem: entrevistador/entrevistado (ou teórico/caso exemplar) do ponto de vista do autor e sacerdote/fiel, do ponto de vista da entrevistada. 
"De Raízes e Rezas" trabalha também a partir de entrevistas que servem de núcleo central para o documentário, mas, diferentemente dos outros dois filmes, não tem caráter de estruturação. Ao mesmo tempo, percebe-se uma clara mudança na dinâmica de diálogo dentro e fora da cena. Em primeiro lugar, observa-se nas entrevistas do raizeiro e da rezadeira um espaço maior para o relato de uma experiência individual. Num movimento raro na Caravana, os dois depoentes se apresentam, o que garante uma personalização da experiência, que não serve aqui ao propósito de ilustração de tese ou da criação de um personagem tipo. A montagem, por sua vez, diferentemente dos recortes constantes de "Frei Damião" preserva a linearidade dos depoimentos, que aparecem no filme como núcleos autônomos que não participam de uma possível argumentação do enunciador. O resultado é o esboço de uma "voz do outro", que ainda está para ser encontrada.

Através deste levantamento de questões e do estabelecimento de relações entre procedimentos adotados por esses filmes e abordagens características de tradições documentárias que os precedem e os sucedem, esse trabalho buscou situar esta seleção da Caravana Farkas dentro um movimento de transição que pode ser observado no documentário brasileiro do período. Estas tendências de mudança podem ser entendidas não apenas como reflexo de mudanças no contexto brasileiro de produção, mas também como o que poderia ser considerada uma evolução natural das formas documentárias. Como observa Nichols, a busca constante de melhor representar "as coisas como elas são" está ligada à superação de procedimentos que apesar de populares em um determinado momento histórico - perdem com o passar do tempo sua eficácia.

Neste momento histórico específico do documentário brasileiro - a passagem entre as décadas de 60 e 70 -, é a "voz do saber", ou a voz em off autorizada, que se vê questionada. Assim, são através de múltiplas aproximações e afastamentos que estes três filmes se colocam entre dois pólos - a "voz do dono" e a "voz do outro" - constituindo-se como peças híbridas onde as mais diversas influências se misturam: o documentário expositivo da tradição griersoniana e, mais 
especificamente, o "modelo sociológico" brasileiro; as técnicas e estratégias observacionais do cinema direto; e o documentário de entrevistas que se populariza na década de 70 . 


\section{BIBLIOGRAFIA}

LIVROS E TESES

ANOS 70: Trajetórias. Vários Autores. São Paulo, Iluminuras, Itaú Cultural, 2005.

AUMONT, Jacques e outros. A Estética do Filme. São Paulo, Papirus Editora, 2003.

AUMONT, Jacques, MARIE, Michel. Dicionário Teórico e Crítico de Cinema; tradução Eloísa Araújo Ribeiro. Campinas, São Paulo, Papirus Editora, 2003.

BARNOUW, Erik. Documentary: A History of the non-fiction film. Oxford University Press, 1993.

BERNARDET, Jean-Claude. Cineastas e imagens do povo. São Paulo, Cia das Letras, 2003.

BERNARDET, Jean-Claude. Brasil em Tempo de Cinema: Ensaio sobre o Cinema Brasileiro de 1958 a 1966. Rio de Janeiro, Editora Civilização Brasileira, 1967.

BERNARDET, Jean-Claude, AVELLAR, José Carlos, MONTEIRO, Ronald F. Anos 70/ Cinema. Rio de Janeiro, Europa Editora, 1979-1980.

CARROLL, Noel. Ficção, não-ficção e o cinema da asserção pressuposta: uma análise conceitual. In: RAMOS, Fernão Pessoa (org.). Teoria Contemporânea do Cinema, Volume II: Documentário e narratividade ficcional. São Paulo, Editora Senac SP, 2005.

COLLET, Jean, MARIE, Michel, PERCHERON, Daniel, SIMON, Jean-Paul, VERNET, Marc. Lectures du Film. Paris, Editions Albatros, 1980 
DA-RIN, Sílvio. Espelho Partido: Tradição e transformação do documentário cinematográfico. Dissertação de Mestrado. ECO. UFRJ, 1995

FARKAS, Thomaz. Cinema Documentário: Um Método de Trabalho. Dissertação de Doutorado - Departamento e Jornalismo e Editoração. Escola de Comunicações e Artes. Universidade de São Paulo, 1972.

FAVARETTO, Celso. Tropicália, Alegoria, Alegria. 3ª Edição. São Paulo, Ateliê Editorial, 2000. FERRAZ, Marcelo Carvalho. Lina Bo Bardi. São Paulo, Empresa das Artes, 1993.

GALVÃO, Maria Rita, BERNARDET, Jean-Claude. O Nacional e o Popular na Cultura Brasileira - Cinema. São Paulo, Editora Brasiliense, 1981.

MESQUITA, Cláudia. Deus está no particular: Representações da experiência religiosa em dois documentários brasileiros contemporâneos. Dissertação de Doutorado - Área de Estudo dos Meios e da Produção Mediática. Escola de Comunicações e Artes. Universidade de São Paulo, 2006.

MUNIZ, Sérgio (org). A Caravana Farkas. Documentários - 1964-1980. Catálogo da mostra realizada no Centro Cultural Banco do Brasil/RJ, julho/1997.

NICHOLS, Bill. A voz do documentário. In: RAMOS, Fernão Pessoa (org.). Teoria Contemporânea do Cinema, Volume II: Documentário e narratividade ficcional. São Paulo, Editora Senac SP, 2005.

NICHOLS, Bill. Introdução ao Documentário; tradução Saddy Martins. Campinas, SP, Papirus, 2005. 
NICHOLS, Bill. Representing reality, issues and concepts in Documentary. Bloomington and Indianopolis: Indiana University Press. 1991.

NIETZCHE. A Origem da Tragédia. Tradução, apresentação e comentários Luís Lourenço. Lisboa, Lisboa Editora, 2005.

ODIN, Roger. A questão do público: uma abordagem semiopragmática. In: RAMOS, Fernão Pessoa (org.). Teoria Contemporânea do Cinema, Volume II: Documentário e narratividade ficcional. São Paulo, Editora Senac SP, 2005.

ODIN, Roger. Film documentaire, lecture documentarisante, in: ODIN, R e LYANT, J. C. (ed.): Cinémas et réalites. Saint-Etienne: Universidade de Saint-Etienne, 1984

ORTIZ, Renato. Cultura Brasileira e Identidade Nacional. SP, Editora Brasiliense, 1985.

PARENTE, André. Narrativa e Modernidade. Campinas, Papirus, 2000.

RAMOS, Fernão Pessoa. Cinema verdade no Brasil. In: TEIXEIRA, Francisco Elinaldo (org). Documentário do Brasil: tradição e Transformação. São Paulo, Summus, 2004.

RENOV, Michael (ed.). Theorizing Documentary. Nova Iorque, Routledge, 1993.

ROCHA, Glauber. Revisão crítica do Cinema Brasileiro. São Paulo, Cosac \& Naify, 2003.

ROCHA, Glauber. Revolução do cinema novo. São Paulo, Cosac \& Naify, 2004. 
SALLES GOMES, Paulo Emílio. Cinema: Trajetória No Subdesenvolvimento. 2ed. São Paulo, 1996.

SCHWARZ, Roberto. Cultura e Política (1972). São Paulo, Paz e Terra, 2001.

STRINATI, Dominic. Cultura popular: uma introdução. Tradução Carlos Slak. São Paulo, Hedra, 1999.

SUSSEX, Elizabeth, The rise and fall of British documentary. The story of the film movement founded by John Grierson. Berkley, The University of California Press

XAVIER Ismail. O Cinema Brasileiro Moderno. São Paulo, Paz e Terra, 2001.

XAVIER Ismail. Sertão Mar: Glauber Rocha e a Estética da Fome. São Paulo, Brasiliense, 1983.

WILLIAMS, Raymond. Tragédia Moderna: tradução Betina Bischof. São Paulo, Cosac \& Naify, 2002.

PUBLICAÇÕES PERIÓDICAS

CADERNOS DE RTV. Curso de Rádio e Televisão da Faculdade de Comunicação Multimídia da UMESP. São Bernardo, número 01, abril de 2000.

Libertar-se da Câmera na Forma Vazia (com uma introdução de Amir Labaki). Revista Cinemais, número 28, p.7-39. Rio de Janeiro, Editora Cinemais, abril de 2001.

Conversa com Linduarte Noronha. Da Alegria de Aruanda ao Absurdo da Câmera Russa. Revista Cinemais, número 22, p.7-31. Rio de Janeiro, Editora Cinemais, abril de 2000. 
NEVES, David. A Descoberta da Espontaneidade (Breve histórico do cinema-direto no Brasil), 1966. Reproduzido na Revista Contracampo, número 39/40, em 2002. (www.contracampo.com.br)

Olhar o Brasil. Revista do Patrimônio Histórico e Artístico Nacional, número 29. Brasília, IPHAN, 2001.

SANTEIRO, Sérgio. Conceito de Dramaturgia Natural. Revista Filme Cultura, número 30, p.8086. Rio de Janeiro, Embrafilme, agosto de 1978.

XAVIER, Ismail. Indagações em torno de Eduardo Coutinho Revista Cinemais, número 36. p. 221-237. Rio de Janeiro, Editora Cinemais, dezembro de 2003.

SITES

www.mnemocine.com.br - Depoimento de Sérgio Muniz ao site Mnemocine/ Aruanda. Depoimento e edição: Flávio Brito. São Paulo, 12/09/2001.

http://www.itsalltrue.com.br/iat2001 imprensa 04.htm - Texto: Festival faz homenagem ao diretor de "Viramundo", clássico do documentário brasileiro. Site do Festival É Tudo Verdade, edição 2000. 


\section{FILMOGRAFIA DA CARAVANA FARKAS}

\section{BRASIL VERDADE}

“Memória do Cangaço" (Paulo Gil Soares, b\&p, 30’35mm,1965)

“Nossa Escola de Samba” (Manuel Gimenez, b\&p, 30’16mm, ampliado 35mm,1965)

“Subterrâneos do Futebol” (Maurice Capovilla, b\&p, 30’/16mm, ampliado 35mm,1965)

“Viramundo" (Geraldo Sarno, b\&p, 40’/16mm, ampliado 35mm,1965)

\section{A CONDIÇÃO HUMANA}

Geraldo Sarno (09 documentários)

“A Cantoria” (cor, 14’30”/ 16mm, ampliado 35mm,1970)

“Casa de Farinha” (cor, 13’/16mm, 1969-1970)

“Jornal do Sertão" (b\&p, 13’30”/ 16mm, ampliado 35mm,1970)

“O Engenho" (cor, 09’30”/ 16mm, ampliado 35mm,1970)

“Os Imaginários” (b\&p, 10’1 16mm, 1970)

"Padre Cícero" (cor e b\&p, 10’/16mm, 1971)

“Região: Cariri” (cor e b\&p, 10’/16mm, ampliado 35mm, 1970)

“Vitalino Lampião" (b\&p, 09’05”/ 16mm, 1969)

"Viva Cariri!" (cor e b\&p, 36'/ 16mm, ampliado 35mm,1970) 
Paulo Gil Soares (06 documentários)

“A Mão do Homem” (cor, 18’05”/ 16mm, ampliado 35mm,1969-1970)

“A Morte do Boi” (cor, 10’05”/ / 16mm, ampliado 35mm, 1970)

“A Vaquejada” (cor, 10’05”/ / 16mm, ampliado 35mm, 1970)

“Frei Damião: Trombeta dos Aflitos, Martelo dos Hereges” (cor, 20’ / 16mm, ampliado 35mm, 1970)

“Jaramataia" (cor, 20’30"/ 16mm, ampliado 35mm, 1970)

“O Homem de Couro" (cor, 20’30"/ 16mm, 1970)

Sérgio Muniz (04 documentários)

“Beste" (cor, 20’/ 16mm, 1970)

“A Erva Bruxa” (cor, 20’30”/ 16mm, 1969-70)

“De Raízes e Rezas, entre outros” (cor, 37’/16mm, 1972)

“Rastejador, s.m.” (cor, 25’ 16mm ampliado 35mm, 1970)

COMPILAÇÕES

"Brasil Verdade" (cor e b\&p, $130 \mathrm{~min}, 16 \mathrm{~mm}$ ampliado 35mm, 1967)

"Herança do Nordeste" (cor e b\&p, 131 min, 16mm ampliado 35mm, 1971) 